\title{
AVALIAÇÃO DA EFETIVIDADE DE UM PROGRAMA DE SAÚDE BUCAL DIRECIONADO A GESTANTES SOBRE A EXPERIÊNCIA DE CÁRIE DE SEUS FILHOS
}

\author{
RÉGIA LUZIA ZANATA
}

Tese apresentada à Faculdade de Odontologia de Bauru, da Universidade de São Paulo, como parte dos requisitos para obtenção do título de Doutora em Odontologia, área de Dentística.

(Edição Revisada)

BAURU

2001 


\title{
AVALIAÇÃO DA EFETIVIDADE DE UM PROGRAMA DE SAÚDE BUCAL DIRECIONADO A GESTANTES SOBRE A EXPERIÊNCIA DE CÁRIE DE SEUS FILHOS
}

\author{
RÉGIA LUZIA ZANATA
}

Tese apresentada à Faculdade de Odontologia de Bauru, da Universidade de São Paulo, como parte dos requisitos para obtenção do título de Doutora em Odontologia, área de Dentística.

(Edição Revisada)

Orientadora: Profa. Dra. Maria Fidela de Lima Navarro

BAURU

2001 

Zanata, Régia Luzia
Z16a. Avaliação da efetividade de um programa de saúde bucal direcionado a gestantes sobre a experiência de cárie de seus filhos / Régia Luzia Zanata -- Bauru, 2001. $175 \mathrm{p}$ : il. ; $30 \mathrm{~cm}$.

Tese. (Doutorado) -- Faculdade de Odontologia de Bauru. Universidade de São Paulo.

Orientadora: Profa. Dra. Maria Fidela de Lima Navarro

Autorizo, exclusivamente para fins acadêmicos e científicos, a reprodução total ou parcial desta tese, por processos fotocopiadores e outros meios eletrônicos

Autora:

Data: 


\section{RÉGIA LUZIA ZANATA}

29 de dezembro de 1969

Bauru - São Paulo

$1988-1991$

1992

$1993-1996$

$1997-2001$

2000

Associações
Nascimento

Curso de graduação em Odontologia Faculdade de Odontologia de Bauru Universidade de São Paulo

Aperfeiçoamento em Dentística Faculdade de Odontologia de Bauru, USP

Curso de pós-graduação em Dentística em nível de Mestrado, na Faculdade de Odontologia de Bauru, USP

Curso de pós-graduação em Dentística, em nível de Doutorado, na Faculdade de Odontologia de Bauru, USP

Professora Adjunta da disciplina de Dentística, na Faculdade de Odontologia da Universidade Paulista, campus Bauru

IADR - International Association for Dental Research 
"Há grandes homens que fazem com que todos se sintam pequenos.

Mas o verdadeiro grande homem é aquele que faz com que todos se sintam grandes."

Gilbert K C. 
"Vitorioso não é aquele que vence os outros, mas o que vence a si mesmo, dominando seus víciose superando seus defeitos. A vitória sobre si mesmo é muito mais difícil, muito mais desafiadora, e quem consegue isto pode ser classificado como verdadeiro herói.

Jamais desanime, se desta vez não conseguiu, recomece e um dia será vitorioso." 


\title{
DEDICO ESTE TRABALHO
}

\begin{abstract}
A Deus,
pelo D om da Vida, pela faculdade da inteligência, pela presença constante, sempre guiando meus passos e preenchendo de sentido minha existência. A gradeço também pelo amparo e proteção, pela minha saúde, pela minha família, pela oportunidade de ser útil a meu próximo e pelas coisas que minha alma ainda não consegue enxergar.
\end{abstract}

\section{Aos meus pais,}

agradeço por me presentearem com a luz mais brilhante que puderam encontrar:

o Estudo.

\section{Aos meus filhos, Vitória e Julio}

que encheram minha vida de al egria, mostrando-me o mais profundo sentido do amor e de quem roubei preciosos momentos de convivência durante a realização deste trabalho. E, embora ainda não compreendam a razão disto tudo, são 0 principal incentivo às minhas realizações. 


\section{Ao meu marido, Menelau}

pelos momentos de solidariedade, entendendo minhas ausências e acreditando em nós.

\section{Aos meus familiares e amigos}

pontos de apoio na jornada da vida. Agradeço especialmente a Lia, a Léa , a Neide, a Sílvia, a Denise, e a Tânia, pois vocês, cada um a seu modo, viabilizaram a finalização desta Tese. 


\section{AGRADEÇO ESPECIALMENTE}

\section{“ Estar à frente}

V ocê já reparou como entre tantas pessoas que fazem exatamente a mesma coisa sempre existem aquelas que encontram uma maneira de fazer melhor?

Gente que se supera. Gente que insiste, persiste, que acredita tanto em suas idéias que não descansa en quanto não consegue colocálas em pé. Esse é o tipo de gente que você reconhece de longe, porque está à frente, servindo de exemplo, servindo de referência para todos que vêm depois.

São pessoas assim que movem o mundo e ampliam horizontes. São pessoas assim que fazem as coisas acontecerem. “ 


\section{AGRADECIMENTOS}

A gradeço:

À Cirurgiã-dentista Sílvia Helena Barbosa que me auxiliou em várias etapas deste estudo, tornando os momentos difíceis mais fáceis de serem suplantados e fico feliz pela amizade que se fortaleceu através da convivência profissional.

A o Prof. D r. Eduardo Batista Franco, que meingressou no caminho da pesquisa através de sua orientação. O brigada pela confiança e apoio.

A o Prof. Dr. José Carlos Pereira pela gratificante orientação na clínica de pós-graduação e pelo incentivo profissional presente no decorrer do curso.

Ao corpo docente do Departamento de Dentística, sempre prestativo, mostrando-me a importância da busca do conhecimento e ensinando-me a entender e amar a 0 dontologia.

A o Prof. D r. José R oberto Pereira Lauris pelo auxílio na realização e interpretação estatística dos resultados reportados. 
À Prof.a. Dra. Odila Pereira da Silva Rosa pelas valiosas informações transmitidas.

A o Prof. Dr. José Valdes Conti e ao Prof. Dr. Rubens Valera pela oportunidade de ingresso na carreira docente.

À colega Lúcia Coelho Pereira pelo auxílio na ilustração e impressão deste trabalho.

À cirurgiã-dentista A ndreza Russo de Godoy pela colaboração na execução da parte experimental deste estudo.

À Secretária de Saúde Dra. Eliane Telles N unes e à Dra. Sônia, pela administração sensível aos problemas sociais e voltada à implementação de ações preventivas em saúde.

A o Setor de Supervisão O dontológica da Secretaria de Saúde de Bauru, que viabilizou e incentivou o desenvolvimento deste estudo.

A os funcionários das U nidades de Saúde em que desenvolvi este estudo, muito obrigada pela atenção e receptividade.

Às pacientes e seus filhos, pela colaboração e boa vontade, sem as quais este trabal ho se tornaria inviável.

A os funcionários do D epartamento de D entística, pela dedicação e atenção proporcionadas. 
A os funcionários da Biblioteca pela atenção e orientação proporcionada durante todo meu convívio nesta casa.

A os funcionários da pós-graduação por toda eficiência e atenção com que realizam seu trabalho.

Ao tio Gastão e ao Prefeito deste Campus, Prof. Dr. Dagoberto Sottovia Filho, pela administração sensível aos encargos da maternidade, viabilizando o funcionamento do Berçário Leite e A mor.

À todas as funcionárias do Berçário Leite e A mor pelo carinho e cuidados prestados ao meu filho enquanto eu executava este estudo.

A os colegas do curso de pós-graduação pela agradável convivência e pela troca de conhecimentos através dos quais muito aprendi.

À FAPESP (Fundação de Amparo à Pesquisa do Estado de São Paulo) pelo suporte técnico, científico e financeiro fundamentais para realização deste trabalho.

A todos que, de alguma forma, me ajudaram e contribuíram para que este trabal ho pudesse ser realizado. 


\section{SUMÁRIO}

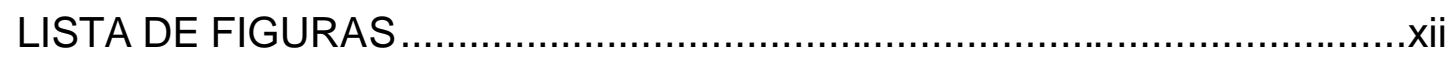

LISTA DE ABREVIATURAS E SÍMBOLOS.................................................

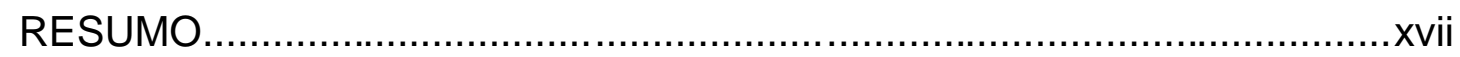

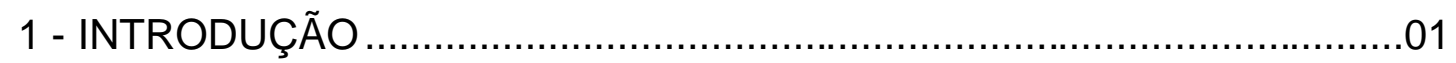

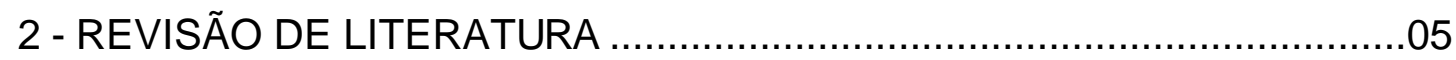

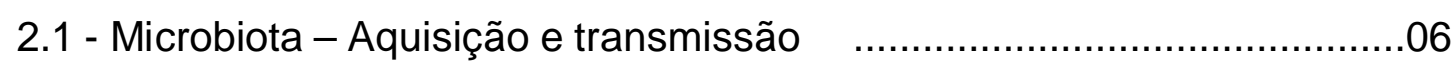

2.2 - Cárie na primeira infância - epidemiologia $\quad$ ………………….......12

2.3 - Avaliação das condições de saúde bucal e do nível de conhecimento

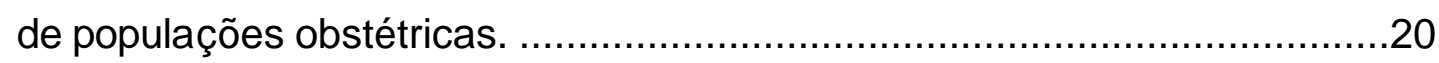

2.4 - Atuação odontológica nos períodos pré e pós natal.................................32

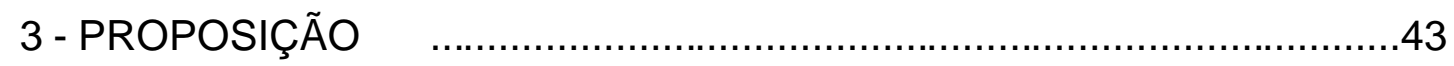

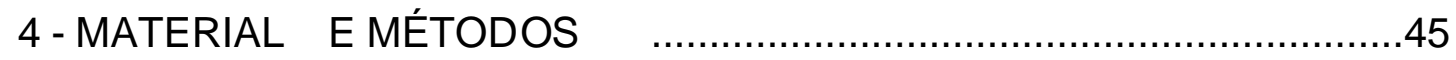

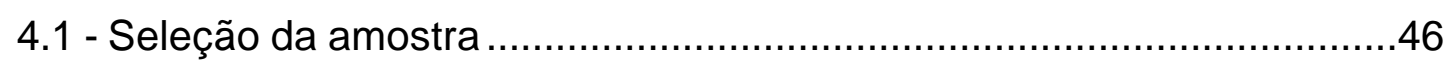

4.2 - Fase experimental - Etapa inicial - "Baseline" ………………….......47

4.3 - Fase experimental - Implementação das medidas preventivas ........54

4.4 - Fase experimental - Avaliação de 6 meses ………………….......61

4.5 - Fase experimental - Avaliação de 12 meses ...................................62

4.6 - Fase experimental - Avaliação final - 24 meses ...............................63

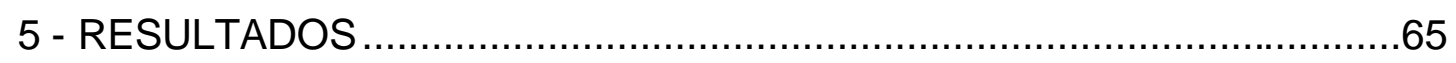

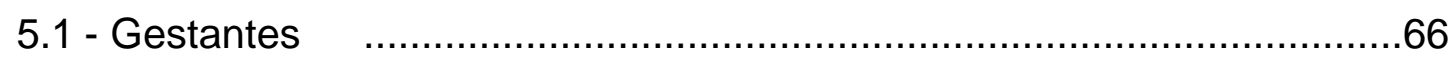

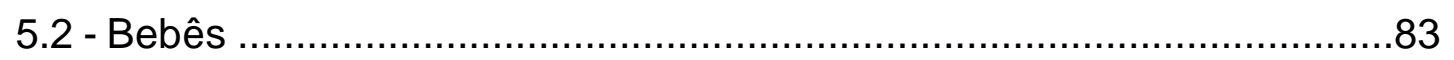

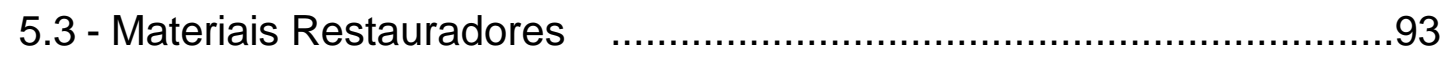

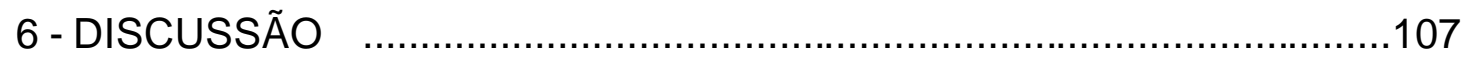

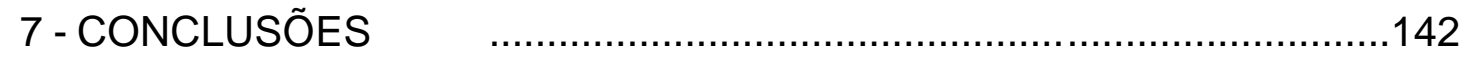

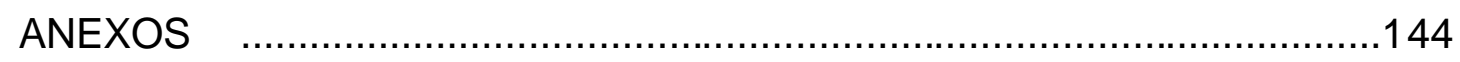

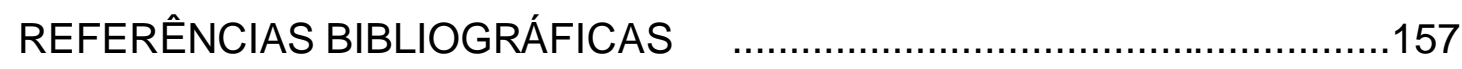

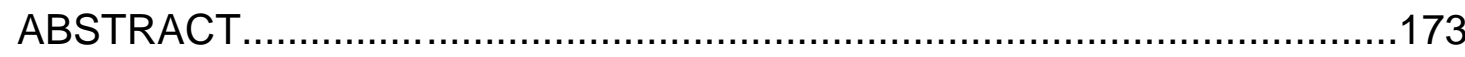




\section{LISTA DE FIGURAS}

Figura 1 Índice Comunitário de Necessidades de Tratamento Periodontal .50

Figura 2 A. Subdivisões da superfície dentária para avaliação do índice PHP (patient hygiene performance); B. Exemplificação de um escore 3; C. Exemplo de um escore $1 ; \mathrm{D}$. Exemplo de um escore 4 .51

Figura 3 Seqüência clínica do procedimento restaurador executado na adequação bucal. 60

Figura 4 Distribuição das pacientes dos grupos Experimental e Controle segundo o número de superfícies cavitadas .72

Figuras 5 a 7 Condição bucal inicial das gestantes .73

Figura 8 Incremento médio de cárie das mães dos grupos Experimental e Controle .74

Figura 9 Incremento médio de cárie das mães de bebês sem cárie e cárie-ativos. .78

Figura 10 Experiência de cárie (média de cavidades e desmineralizações ) dos bebês cárie-ativos dos grupos Experimental e Controle .86 
Figura 11 Experiência de cárie dos bebês (casos clínicos)....87

Figura 12 a 16 Comportamento clínico dos materiais restauradores

105 e 106 


\section{LISTA DE ABREVIATURAS E SÍMBOLOS}

\begin{tabular}{|c|c|c|}
\hline $\mathrm{ABA}$ & - & Associação Brasileira de Anunciantes \\
\hline ART & - & Técnica de restauração atraumática \\
\hline $\mathrm{c} / \mathrm{a}$ & - & cárie-ativa(o) \\
\hline cavfiss & - & cavidade em superfície dentária de fisssura \\
\hline cavlisa & - & cavidade em superfície dentária lisa \\
\hline ceod & - & número de dentes decíduos cariados, extraídos e obturados \\
\hline ceos & - & $\begin{array}{l}\text { número de superfícies cariadas, extraídas e obturadas (dentição } \\
\text { decídua) }\end{array}$ \\
\hline DC & - & número de dente cariados \\
\hline CPOD & - & número de dentes cariados perdidos e obturados \\
\hline CPOS & - & número de superfícies dentárias cariadas, perdidas e obturadas \\
\hline CT & - & Controle \\
\hline CTS & - & Capacidade tampão da saliva \\
\hline DMFS & - & "Decayed Missed Filled Surfaces" \\
\hline DS & - & "decayed surface" \\
\hline ds & - & "decayed surface"' \\
\hline EX & - & Experimental \\
\hline Fig. & - & figura \\
\hline FOB & - & Faculdade de Odontologia de Bauru \\
\hline $\mathrm{H}_{3} \mathrm{PO}_{4}$ & - & ácido fosfórico \\
\hline ICNTP & - & índice comunitário de necessidades de tratamento periodontal \\
\hline
\end{tabular}




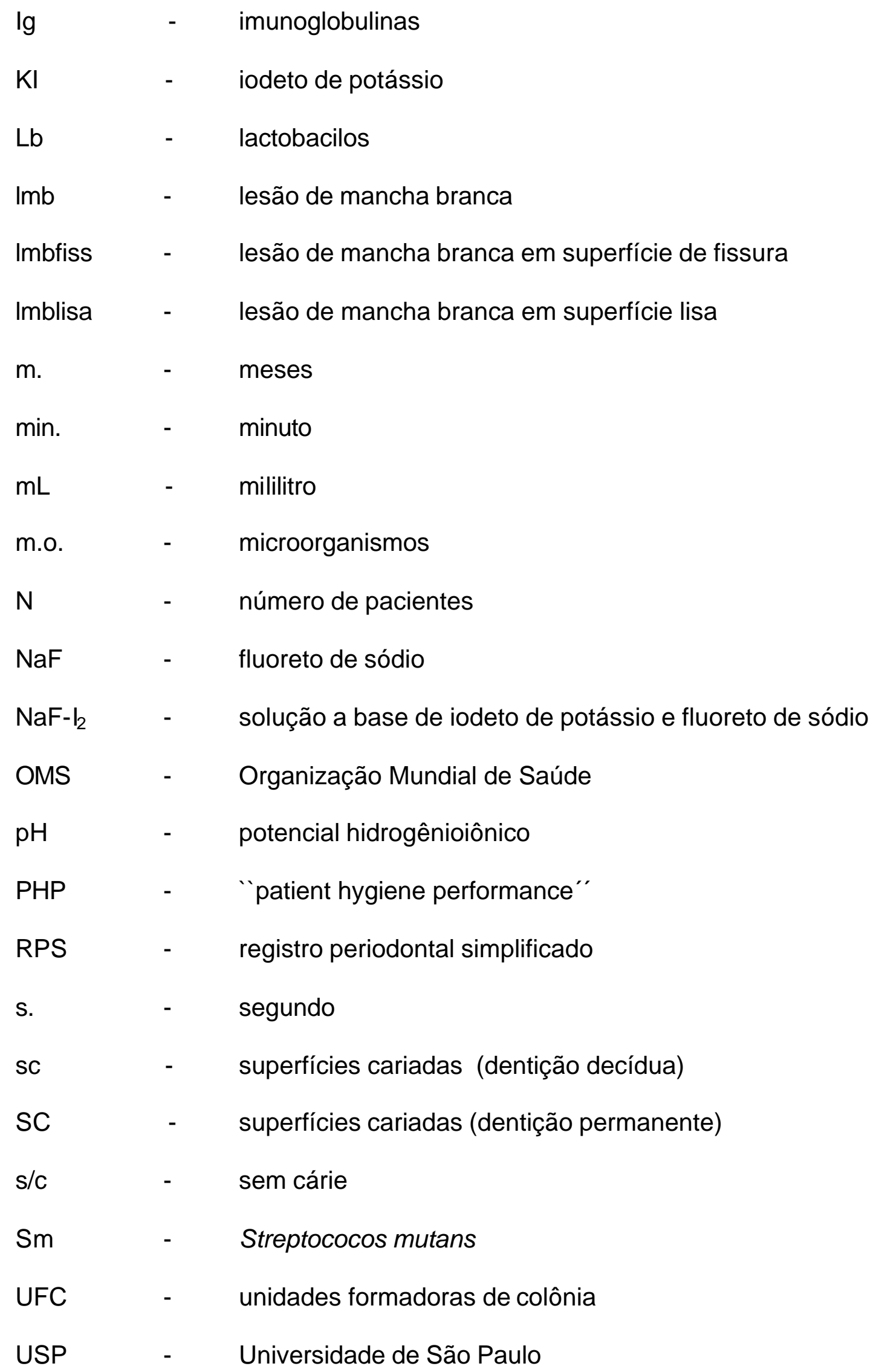




$\begin{array}{lll}> & - & \text { maior } \\ < & - & \text { menor } \\ \text { ף } & - & \text { All Dent, Dois Córregos, Brasil } \\ \text { 【ף } & - & \text { Herpo LTDA, Rio de Janeiro, Brasil } \\ & - & \text { Dentsply LTDA, Petrópolis, Brasil } \\ & - & \text { Vigodent, Brasil } \\ & - & \text { GC Dental Co., Japão }\end{array}$


R esu mo 


\section{RESUMO}

O objetivo deste estudo longitudinal foi avaliar a efetividade de um programa de saúde bucal, iniciado durante a gestação, sobre a experiência de cárie de primigestas e seus filhos. Oitenta e uma gestantes, pertencentes a classes sociais pouco favorecidas, foram selecionadas com base no diagnóstico clínico de lesões de cárie ativas em superfícies dentárias livres e proximais (SC inicial 13,98). A condição dentária inicial foi estabelecida através do índice CPOS e do diagnóstico das lesões de mancha branca. A condição periodontal foi avaliada a partir do índice ICNTP. O fluxo salivar e a capacidade tampão da saliva também foram analisados. Sessenta e quatro pares mãe-filho finalizaram o estudo, estando 34 no grupo experimental e 30 no grupo controle. Setenta e cinco por cento das mães tinham entre 14 e 20 anos no início do estudo e foram classificadas como adolescentes. Ambos os grupos receberam uma abordagem educativa (informação sobre a etiologia, transmissão e prevenção da doença cárie, instruções de higiene oral e aconselhamento sobre dieta). O grupo experimental recebeu adicionalmente tratamento com antimicrobianos (profilaxia profissional e aplicações tópicas de flúor gel e solução a base de iodo) e adequação bucal utilizando cimento de ionômero de vidro. A prevalência de crianças cárie-ativas com a idade de dois anos foi de $33,3 \%$ no grupo controle e $14,7 \%$ no grupo experimental. Foi observada diferença significativa na prevalência de cárie entre crianças com e sem placa dentária visível $(p=0,032)$. O número médio de superfícies com lesões de cárie (incluindo as desmineralizações) foi maior para as crianças do grupo controle quando comparadas às do grupo teste $(6,3 \mathrm{x}$ 3,2), porém sem atingir significância estatística. Cinco crianças no grupo controle 
exibiram seis ou mais superfícies dentárias cariadas. Esta situação não foi observada em criança alguma do grupo experimental. O incremento de cárie na dentição da mãe foi computado ao longo do estudo e apresentou correlação significativa com a incidência de cárie na dentição das crianças ( $p=0,0009)$. Estes dados suportam a evidência de associação entre a incidência de cárie na primeira infância e a presença de placa, assim como a influência significativa de fatores maternos. 
1 - I n trod u çã o 


\section{1 - INTRODUÇÃO}

A cárie é uma doença infecto-contagiosa de etiologia multifatorial decorrente da interação dos fatores hospedeiro, microbiota e substrato durante um determinado tempo, ou seja, a cárie é uma doença transmissível fortemente modificada pela dieta ${ }^{109}$.

A aquisição precoce de uma microbiota cariogência pode ocorrer durante a formação do ecossistema bucal em tenra idade, concomitantemente ao irrompimento da dentição decídua ${ }^{15,16,24}$.

Neste modelo de transmissão a principal fonte de microorganismos cariogênicos é a saliva materna ${ }^{7,13,14,68,86}$.

Entre os fatores moduladores do sucesso da primo-colonização da cavidade bucal por microorganismos cariogênicos, especificamente os estreptococos do grupo mutans, encontramos o número de células disponíveis para implantação ${ }^{16,17}$, a freqüência de inoculação ${ }^{46}$, a virulência dos microorganismos ${ }^{86}$, a presença de superfícies dentárias virgens ${ }^{24,64}$ e de uma dieta favorável ao metabolismo bacteriano ${ }^{12,67}$.

A mãe é a principal responsável pela saúde bucal de seus filhos, tanto pela transmissão precoce de bactérias cariogênicas como pelo estabelecimento de hábitos alimentares e de higiene inadequados, e o seu padrão de saúde bucal tende a ser continuado em seus filhos ${ }^{18,25,35,52,56,77,90,96,114}$.

O postulado acima confronta-se com a falta de informação e as necessidades odontológicas acumuladas observadas em gestantes e recém-mães 
estudadas em diversos países, principalmente em grupos de baixa renda e pouca escolaridade ${ }^{10,25,30,36,40,45,48,79,84,89,92,93,96,97,99,101,112,124}$.

A atenção odontológica durante a gestação deve ser priorizada, porque esta fase mostra-se favorável à implementação de medidas educativas/ preventivas, pois nota-se uma maior receptividade da futura mãe, principalmente da primigesta, à aquisição de novos conhecimentos que possam favorecer a saúde e bem estar de seu filho ${ }^{18,20,25,36,48,79,97,99,112}$. E também porque a negligência quanto à saúde bucal neste período causa prejuízos agravados à mãe e pode colocar a saúde do feto em risco $30,31,45,63,102$, além de aumentar significativamente o risco de primo-infecção precoce de seus filhos por "Streptococcus mutans" e outras bactérias patogênicas ${ }^{7,9,17,35,39,42,43,60,63}$.

Porém, nas camadas sociais menos favorecidas, a atuação do cirurgião-dentista na fase pré-natal ainda é deficiente e cercada por muitos medos e preconceitos $^{30,79,92,97}$ que contribuem para perpetuação de um ciclo pernicioso de manutenção da cárie em grupos altamente afetados pela doença e que raramente recebem atenção odontológica curativa ou preventiva, e apresentam um perfil resistente à mudança de atitude/comportamento.

A abordagem preventiva precoce, denominada por BLINKHORN ${ }^{18}$ de "socialização antecipatória" tem o objetivo de formar hábitos ao invés de tentar mudar rotinas inadequadas já estabelecidas e aceitas pela criança sem questionamento por entenderem o padrão de cuidados instituído como natural.

Uma filosofia preventiva para a primeira infância precisa ser encorajada, pois, apesar dos relatos epidemiológicos mostrarem grande variação na prevalência da cárie nos primeiros anos de vida, observações comuns aos estudos 
são o aumento da prevalência da doença com a idade, o impacto da implantação precoce de estreptococos do grupo mutans na experiência futura de cárie, e a presença de grupos de polarização, os quais precisam ser identificados com antecedência 9 9,12,39,42,43,58,59,61,74,75,81,108,110,113,118,121,122.

Vários estudos foram desenvolvidos com gestantes e recém-mães com altas contagens de microorganismos cariogênicos evidenciando o risco da criança em função da atividade de cárie da mãe 20,24,32,44,58,59,61,62,104,108.

Os resultados de alguns destes estudos $20,44,58,59,61,104,108$ revelaram que medidas preventivas direcionadas às mães mostraram-se efetivas em reduzir ou postergar a experiência de cárie de seus filhos. Esse fato motivou o desenvolvimento de um programa preventivo direcionado a gestantes cárie-ativas, pertencentes a classes sociais menos favorecidas, com o objetivo de avaliar a efetividade de uma abordagem pré-natal adaptada a realidade brasileira, pois, a condição sócio-culural adversa poderia prejudicar a motivação do grupo, produzindo resultados diferentes. 


$$
\begin{array}{r}
2 \text { - Revi sã o de } \\
\text { Litera tu ra }
\end{array}
$$




\section{2 - REVISÃO DE LITERATURA}

\subsection{Microbiota - Aquisição e transmissão}

Anteriormente à década de 60 destacava-se o papel da hereditariedade na etiologia da cárie ${ }^{107}$ : “ as características de nossos dentes são produto de nossa herança, do cuidado que dedicamos a eles e da natureza das modificações ambientais como ácidos, bactérias e dieta, mas, fundamentalmente nossos dentes são o que são devido a nossa herança genética “.

Em $1946 \mathrm{KLEIN}^{56}$ com o propósito de examinar a relação entre o CPOD (número de dentes cariados, perdidos e obturados) de genitores e seus filhos, estudou 1.150 famílias de ascendência nipônica. Encontrou uma consistente correlação entre a experiência de cárie de genitores e filhos, observando "uma significativa tendência dos filhos refletirem na sua própria experiência de cárie o padrão já demonstrado por seus pais (pais e mães) “. Atribuiu os achados a "uma susceptibilidade à doença envolvendo fortes vetores familiares e talvez relacionada ao sexo", pois, constatou que variações no CPOD dos pais tinham apenas uma suave correlação positiva com a experiência de cárie dos filhos, enquanto as variações do CPOD materno estavam fortemente relacionadas com a experiência de cárie dos herdeiros, principalmente com as meninas.

Os estudos com animais "germ-free" e os revolucionários trabalhos de KEYES ${ }^{53,107}$ provaram a hipótese de ser a cárie uma doença fundamentalmente microbiológica, sugerindo ainda uma via de transmissão bacteriana de modelo "matrilinear" (da mãe para o filho). 
Hoje a cárie é definida como uma doença infecto-contagiosa de etiologia multifatorial, que se manifesta clinicamente através da desmineralização ácida localizada dos dentes ${ }^{64}$. A desmineralização é decorrente da fermentação de carbohidratos por microrganismos acidogênicos. A susceptibilidade do hospedeiro e fatores secundários como o uso de fluoretos e a higiene bucal atuam como moduladores do processo.

A certeza da participação de microorganismos específicos no desenvolvimento deste processo infeccioso foi estabelecida por vários estudos subseqüentes aos de $\mathrm{KEYES}^{53}$, quando um grupo de bactérias fenotipicamente similares denominadas "Streptococcus mutans" (Sm) tornaram-se ostensivamente associadas com o início da cárie e com a atividade e prevalência desta doença ${ }^{7,9,24,60,102,107,109}$. Os lactobacilos (Lb) também são cariogênicos, porém estes microorganismos estão associados a estágios mais avançados da doença cárie ${ }^{109}$.

É de consenso que a cavidade oral é estéril até o nascimento ${ }^{26,73,102}$, sendo prontamente colonizada por uma microbiota bacteriana predominantemente estreptocóccica $^{15}$. A colonização inicial pelo Sm ocorre durante o estabelecimento da microbiota bucal, podendo estar presente de uma forma transeunte na cavidade oral da criança edêntula e de uma forma efetiva logo após a erupção dos primeiros dentes decíduos (necessidade de superfície não descamante para fixação), momento a partir do qual o microorganismos pôde ser detectado em alguns estudos $^{15,24}$, sendo sua detecção a partir da coleta de placa do terço gengival dos dentes mais efetiva e confiável do que a coleta de saliva ou esfregaço ${ }^{9,15}$.

A literatura sustenta que o estabelecimento precoce de Streptococus mutans na cavidade oral de crianças aumenta o risco destas desenvolverem lesões 
cariosas $^{9,39,42,43}$. Estudos abordando o momento mais propício para a infecção, e fontes e rotas de transmissão têm sido realizados ${ }^{14,15,16,17,24,46,60,86}$. Resultados sugerem que a principal fonte de infecção seja a saliva materna ${ }^{7,13,14,46,68,86}$. Métodos usados para confirmar esta hipótese têm se desenvolvido consideravelmente nos últimos anos. Esses dados forneceram informação adequada para o estabelecimento de estratégias preventivas visando evitar ou retardar primo-infecção por Sm.

Em 1975, BERKOWITZ ; JORDAN ${ }^{14}$ preocuparam-se em definir a fonte de infecção destes microorganismos na espécie humana baseando-se na rota de transmissão materna reportada para roedores por KEYES ${ }^{53}$. Observaram uma forte homogeneidade de perfis (sorotipagem e padrões de bacteriocinas) entre Sm isolados de pares mãe-filho, indicando ser a mãe a principal fonte de infecção primária.

Entre os parâmetros moduladores do sucesso da transferência materna BERKOWITZ; TURNER; GREEN 16,17 citam o número de células disponíveis para implantação, o que pode ser avaliado pela concentração de microorganismos na saliva da mãe, e modulado por fatores relacionados ao hospedeiro como a erupção e desenvolvimento dentário. A detecção do microorganismos torna-se mais evidente a partir do estágio final de erupção dos incisivos. Estudando 156 bebês com 6 a 8 incisivos decíduos presentes (idades entre 8 e 18 meses) e suas mães, observaram diferença significativa entre os níveis salivares de Sm de mães de crianças infectadas e não infectadas pelo microorganismo. Coletas positivas para mutans foram encontradas em freqüência nove vezes maior nos bebês filhos de mães com contagens salivares superiores a $10^{5}$ 
unidades formadoras de colônia (UFC) do que nos bebês filhos de mães com contagens de mutans inferiores a $10^{3}(6 \% \times 58 \%)$. Esta associação substancia forte evidência de transferência materna. O valor de $10^{5}$ UFC de Sm na saliva materna foi considerado ponto limítrofe associado com a alta freqüência de infecção, facilitando a identificação de crianças de risco.

KÖHLER; BRATTHALL ${ }^{60}$ em 1978 estudando 36 pares mães-filhos e 31 pais encontraram correlação quantitativa entre os níveis salivares de Sm de genitores e filhos. Esta correlação foi mais evidente para as mães. Embora também tenham sido observado filhos Sm negativos de mães altamente infectadas, ou seja, o alto nível de infecção da mãe por Sm é um fator de risco para seu filho, porém atuam outros fatores como dieta rica em sacarose e hábitos que facilitem a implantação dos microorganismos na boca da criança. Entre as 16 crianças livres de cárie, apenas uma apresentava contagens de $\mathrm{Sm}$ superiores a $10^{5}$, enquanto das 15 crianças com elevada experiência de cárie, 12 apresentavam mais de $10^{5}$ unidades formadoras de colônias de Sm

Resultados similares aos de KÖHLER; BRATTHALL ${ }^{60}$ foram encontrados em outros estudos ${ }^{13,46}$.

A quantidade de m. o. é fundamental na transmissão via saliva, porém, mostra-se de grande importância também a freqüência de inoculação ${ }^{46}$, a virulência dos microorganismos ${ }^{86}$ e as condições favoráveis (susceptibilidade) da boca receptora $^{24}$.

Além do exposto acima, a transmissão destes microorganismos também pode se dar de forma indireta, por meio de alimentos ou objetos 
contaminados $^{35}$. Segundo KÖHLER e BRATHALL ${ }^{60}$ os Sm podem sobreviver de maneira viável em objetos como colheres, maçanetas e relógios por até sete horas.

CAUFIELD; CUTTER; DASANAYAKE ${ }^{24}$ monitoraram longitudinalmente os níveis salivares de microorganismos (Sm, Lb) de 46 pares mãe-filho do nascimento até a idade de 36 meses. As mães selecionadas apresentavam contagem inicial de $\mathrm{Sm}>2,5 \times 10^{4} \mathrm{UFC} / \mathrm{mL}$ de saliva e um CPOS médio $>30$. As contagens bacteriológicas foram feitas a cada 3 meses e as mães foram submetidas a um programa preventivo. Os níveis de Sm e Lb das mães de crianças infectadas ou não por Sm não diferiram estatisticamente. Observaram que a aquisição inicial de Sm ocorreu em 38 crianças com idades entre 19 e 31 meses, média de 26 meses, estabelecendo um período favorável à implantação deste m. o. denominado "janela da infectividade". Neste período ocorre um aumento significativo no número de superfícies dentárias virgens, especialmente as fissuras oclusais e as concavidades proximais dos molares decíduos.

Os dentes recém-irrompidos são particularmente susceptíveis à colonização bacteriana. As crianças também são mais propensas a adquirirem Sm nos primeiros anos de vida, durante o estabelecimento inicial da microbiota oral ${ }^{24,64}$.

LI; CAUFIELD ${ }^{68}$ determinaram a similaridade de genótipos de Sm entre mães e seus bebês através da análise de ácido desoxirribonucleico das bactérias. Genótipos idênticos estavam presentes em $71 \%$ dos 34 pares mãe-filho. A homogeneidade de genótipos foi significativamente mais freqüente para as meninas do que para os meninos ( $88 \% \times 53 \%)$. Em nenhum momento observourse homologia entre os pais e as crianças ou entre maridos e esposas, indicando que este 
microoorganismosdificilmente é transmitido fora da janela da infectividade que ocorre por volta dos 2 anos de idade.

Porém, a colonização pode ser mais precoce em populações com alta prevalência da doença, e uma segunda ocasião propícia à aquisição de Sm surge com a emergência dos dentes permanentes ${ }^{24}$.

A virulência dos microorganismos envolvidos no processo de cárie também mostra-se fator significativo para o sucesso da implantação. O'CONNEL; BOWEN ${ }^{86}$ observaram que Streptococcus altamente acidogênicos e acidúricos foram naturalmente selecionados em ratas submetidos à remoção cirúrgica das glândulas salivares e posteriormente contaminados pelo microorganismos $S$. sobrinus. Os filhotes foram prontamente colonizados e desenvolveram um número de lesões de superfície lisa significativamente maior do que filhotes engaiolados com animais normais também previamente infectados. Sugerem que o controle da atividade de cárie de futuras mães reduza a virulência da bactéria transmitida e retarde ou previna a infecção da criança.

Baseado nestas informações, postula-se que as mães exerçam influência predominante nos níveis de Sm de seus filhos, sendo a fonte primária de infecção. No entanto, a maioria dos experimentos não controla variáveis que poderiam afetar esta correlação como dieta, fluorterapia, higiene oral do bebê, aleitamento materno, atuação do sistema imunológico, presença de irmãos, ou babás e o grau de envolvimento materno, entre outros. 


\subsection{Cárie na primeira infância - epidemiologia}

Segundo WALTER; FERELLE; ISSAO ${ }^{118}$ e MARTINS et al. ${ }^{73}$ nos primeiros anos de vida os bebês podem ser acometidos pela cárie simples onde as lesões geralmente são diagnosticadas nas proximais dos dentes anteriores e nas superfícies oclusais, atingindo menos de seis dentes, e pela cárie rampante ou cárie de mamadeira, primeiro sinal de cárie aguda em seres humanos. A cárie de mamadeira afeta principalmente a superfície vestibular dos incisivos superiores, em geral próximo à margem gengival, podendo estender-se para as faces proximais e superfície palatina. Se o processo não for interrompido o padrão de ataque se dá em função da cronologia de erupção, com a característica clínica marcante de preservação dos incisivos inferiores.

Segundo MILNES ${ }^{81}$ a cárie de mamadeira é altamente virulenta levando à rápida destruição das coroas dentais se não tratada (cárie negligenciada).

WALTER; FERELLE; ISSAO ${ }^{118}$ relatam diversos dados epidemiológicos referentes à cárie da primeira infância. Na faixa etária de 6 a 12 meses reportam prevalência em torno de $5 \%$ para populações do sul do Brasil. A partir do primeiro ano de vida a prevalência da doença aumenta significativamente. Entre as idades de 13 e 18 meses observaram uma prevalência de cárie de 14,25\%, a qual teve um aumento drástico para a idade de 19 a 24 meses $(32,4 \%)$ e atingiu $45,9 \%$ entre 25 e 36 meses.

TOMITA $^{110}$ constatou que na faixa etária de 0 a 2 anos $88,5 \%$ das crianças usuárias de creches do Município de Bauru estavam livres de cárie, sendo que este percentual caía significativamente para a faixa etária de 3 a 4 anos (26\%) e 
o ceos subia de 1,18 (0 a 2 anos) para 5,49 (3 a 4 anos). A tendência continuou para as idades de 5 a 6 anos, onde apenas 9,3\% das crianças estavam livres de cárie. $\mathrm{Na}$ faixa etária de 0 a 2 anos apenas 7,7\% das crianças haviam ido ao dentista e 57,7\% dos pais relataram hábito de escovação diária, sendo a criança responsável pela escovação em $43 \%$ dos casos.

Em 1996 MATTOS-GRANER et al. ${ }^{74}$ avaliaram 322 crianças de baixo nível sócio-econômico, usuárias de creches municipais da cidade de Piracicaba, determinando a prevalência de lesões incipientes (desmineralizações) e cavidades (índice ceos). Na faixa etária de 6 a 12 meses 4,9\% das crianças apresentavam desmineralizações. Nas idades entre 13 e 18 meses, 8\% apresentavam desmineralizações e $3 \%$ cavidades. A prevalência aumentou para 10\% (desmineralizações) e 13,6\% (cavidades) com idades entre 19 e 24 meses.

As desmineralizações foram mais freqüentemente observadas nas superfícies lisas e as cavidades nas superfícies oclusais. Quarenta e seis por cento das lesões diagnosticadas estavam restritas a 17\% das crianças, ressaltando a existência de grupos de polarização altamente afetados pela cárie na primeira infância. Do primeiro para o segundo ano de vida observourse um incremento significativo da prevalência de cavidades (cerca de quatro vezes), o que está de acordo com os trabalhos de WALTER; FERELLE; ISSAO ${ }^{118}$, enfatizando a real necessidade de identificação precoce de crianças de risco e o estabelecimento de programas preventivos.

Relatos epidemiológicos de outros países mostram grande variação na prevalência da cárie na primeira infância. Atuando como moduladores fatores sócioeconômicos e culturais. Porém, uma observação comum aos estudos é o aumento 
significativo da prevalência com a idade, assim como o impacto da implantação precoce de Sm na experiência futura de cárie e a presença de grupos de polarização, altamente afetados pela doença.

Segundo MILNES ${ }^{81}$ investigações conduzidas na Europa reportam prevalência de cárie na primeira infância entre 1 e 12 \%. Na Austrália encontram-se valores próximos a $5 \%$. No continente asiático o autor reporta prevalências de $20 \%$ para a China e 48\% para Indonésia. Na Tanzânia observourse uma larga variação entre prevalência de diferentes regiões do país (1,8\% a 22\%). Nos Estados Unidos e Canadá, diferentemente do observado na maioria dos países, há uma vasta literatura sobre a prevalência de cárie na primeira infância. A prevalência é baixa para populações urbanas em geral, variando de 1 a $5 \%$. Porém, em áreas pouco privilegiadas do ponto de vista sócio-econômico atinge valores próximos a 12\%. Entre grupos étnicos específicos como americanos nativos (indígenas e esquimós) a prevalência é altíssima, atingindo $70 \%$ das crianças, e entre imigrantes hispânicos ou latinos são reportadas prevalências entre 23 e $30 \%$.

DEYU; DAWE ${ }^{33}$ em 1992 avaliaram a prevalência de cárie em crianças chinesas de 0 a 6 anos, moradoras de uma região com baixo conteúdo de flúor na água, nas décadas de 80 e 90. Para a faixa etária de 0 a 1 anos encontraram prevalências de 2,68\% e 5\% nas décadas de 80 e 90 , respectivamente, e os índices ceos observados foram 0,03 e 0,18. Para a idade de 2 anos observaram prevalências de $20 \%$ e $18 \%$ e índices ceos médios de 1,02 e 1,23 para as respectivas décadas. A prevalência de cárie na dentição decídua foi considerada de moderada a alta e crescente com a idade. A porcentagem de crianças livres de cárie diminuiu na década de 90. 
WENDT; HALLOWSTEN; KOCH ${ }^{121}$ em 1991 descreveram a prevalência de cárie (lesões iniciais e manifestas) em crianças suecas com 1 e 2 anos de idade, observando valores de $0,5 \%$ e $7,7 \%$, respectivamente. Aos dois anos o ceos médio das crianças com cárie foi de 6,3, sendo que em 4,7\% das crianças observourse presença de cavidades. Aproximadamente 4,7\% apresentavam lesões apenas nos incisivos e 2,7\% apresentavam mais do que seis superfícies cariadas. Dezoito por cento das crianças eram de origem imigrante e concentraram mais de $50 \%$ das lesões diagnosticadas. Houve diferença significativa entre a prevalência de cárie observada nas crianças suecas $(4,5 \%)$ e a observada na crianças de origem imigrante (22\%). Ressaltaram que as crianças examinadas estavam engajadas em um programa preventivo nacional oferecido pelo Estado, o qual foi considerado suficiente para a maioria das crianças, porém, para uma em cada trinta crianças medidas preventivas adicionais seriam necessárias.

Em estudo subseqüente ${ }^{122}$ os autores avaliaram a prevalência de cárie das crianças com 3 anos. Em termos gerais, 28,3\% das crianças apresentavam lesões (desmineralizações ou cavidades) e o ceos médio foi 2. Entretanto, a condição bucal das crianças suecas diferiu significativamente da condição das crianças de origem imigrante. As prevalências observadas para os grupos de crianças suecas e imigrantes foram, respectivamente $22 \%$ e $50,5 \%$, sendo a prevalência de cavidades 10,7\% e 36,4\%. Entre as crianças que tinham cárie, o número médio de lesões foi 7 . Vinte e cinco por cento das crianças de origem imigrante e $6,4 \%$ das crianças suecas apresentaram mais de seis superfícies cariadas. Um dado interessante foi a constatação de uma alta prevalência de cárie entre as crianças que não haviam comparecido às consultas oferecidas pelo 
programa de saúde bucal do governo com as idades de 1 e 2 anos (61,5\%), sendo que em $46,2 \%$ destas crianças foi diagnosticada presença de cavidades e $34,6 \%$ apresentavam mais de seis superfícies dentárias cariadas. Os autores sugerem ações preventivas estratégicas para crianças de origem imigrantes e crianças faltosas dos exames odontológicos.

GRINDEFJORD et al. $^{42}$, também na Suécia, deram seqüência a uma linha de estudos que corroboraram os achados de WENDT; HALLOWSTEN; $\mathrm{KOCH}^{121,122}$. Em 1991 os autores avaliaram 1095 crianças de 1 ano de idade quanto à presença de Sm e encontraram uma prevalência de 6\%, estando este fato correlacionado positivamente com a freqüência de ingestão de sacarose. Com a idade de 30 meses $76 \%$ das crianças foram avaliadas quanto à prevalência de cárie, levando-se em consideração fatores sociais, étnicos, microbiológicos e de higiene oral. Cerca de $8,4 \%$ das crianças suecas e $14,3 \%$ das crianças de origem imigrante foram diagnosticadas como cárie-positivas, e $28 \%$ estavam colonizadas pelo S. mutans.

Observaram correlação positiva entre a presença de cavidades e a colonização por Sm, a presença de inflamação gengival (8\%) e a origem imigrante. Os dentes mais afetados foram os incisivos superiores (72\% das lesões), e $40 \%$ das crianças apresentavam mais de 3 lesões. A origem imigrante foi considerada um preditor significativo do risco de cárie. Neste grupo houve uma superior prevalência de microorganismos cariogênicos, assim como um consumo de sacarose significativamente maior e um inferior padrão de higiene oral. As crianças de origem não sueca pertenciam, em sua maioria, às classes sociais menos favorecidas, nas 
quais as prevalências observadas foram significativamente superiores as de classes mais altas $(9,7 \% \times 3,6 \%$, respectivamente $)$.

Dando seqüência a este estudo longitudinal, em 1995, GRINDEFJORD et al. ${ }^{43}$ avaliaram a prevalência de cárie das crianças, então com três anos e meio correlacionando este fato com o valor de predição de variáveis pré-determinadas com a idade de 1 ano. Concluíram que a prevalência de cárie aumentou significativamente da idade de 2,5 para 3,5 anos $(11,7 \% \times 37 \%)$. As crianças que apresentavam-se cárie positivas em idade precoce exibiram um padrão de progressão da lesão mais rápido e um incremento significativamente maior do que crianças livres de cárie em avaliações anteriores. Os fatores com valor de predição foram: origem imigrante e nível educacional da mãe, freqüência de ingestão de sacarose e colonização precoce por Sm. Quando todas as variáveis estavam presentes a probabilidade de desenvolver lesões era de $87 \%$. O risco aumentou quase 32 vezes quando comparado ao risco de crianças onde nenhum dos fatores estava presente com a idade de 1 ano.

ALALUUSUA; RENKONEN ${ }^{9}$, na Finlândia, através de monitoramento microbiológico de 39 crianças observaram diferenças significativas na experiência de cárie de crianças conforme a precocidade da detecção de Sm. Treze por cento das crianças mostraram-se Sm positivas antes de 2 anos de idade. Aos 4 anos, 33\% das crianças eram Sm positivas. As crianças que adquiriram o microorganismo precocemente mostraram-se uma experiência de cárie mais severa com a idade de 4 anos $(\operatorname{ceos}=10,6)$ do que crianças que adquiriram Sm entre 2 e 4 anos (ceos = $3,4)$ ou do que as crianças Sm negativas (ceos $=0,3)$. 
ALALUUSUA ; MALMIVIRTA ${ }^{8}$ estudaram 92 crianças de 19 meses de idade buscando identificar fatores associados à futura experiência de cárie. Foram avaliadas as seguintes variáveis: o acúmulo de placa nas superfícies vestibulares dos incisivos superiores, o uso de mamadeira durante o sono, a prevalência de cárie e a contagem de Sm da mãe. Foi feita a correlação entre o risco estimado com a idade de 19 meses e a ocorrência de cárie com a idade de 36 meses. Aos 3 anos 14\% das crianças apresentaram cárie. A ocorrência de lesões mostrourse fortemente associada ao acúmulo de placa que apresentou um valor prognóstico de $91 \%$. As demais variáveis alcançaram uma precisão próxima a $70 \%$. A contagem de Sm da saliva materna correlacionourse com o número e extensão das lesões de cárie das crianças, porém não com a prevalência da doença.

MATTOS-GRANER et al. ${ }^{75}$ em 1998 avaliaram a relação entre a prevalência de cárie em crianças brasileiras de 1 a 2,5 anos e algumas variáveis clínicas (presença de placa visível nos incisivos superiores), microbiológicas (contagem de Sm na saliva), e comportamentais (dieta). Das 142 crianças examinadas, $64 \%$ estavam livres de cárie, $17 \%$ apresentavam apenas desmineralizações e 19\% apresentavam cavidades. Foram diagnosticadas 98 lesões iniciais e 90 cavidades, sendo o sc médio 0,63. Os dentes mais afetados foram os molares inferiores (48\% das lesões). Tanto as lesões iniciais como as manifestas foram diagnosticadas principalmente nas superfícies oclusais (55\% e 65\%, respectivamente), seguidas das superfícies livres (36\% e 15\%, respectivamente) e proximais ( $9 \%$ e $21 \%$, respectivamente).

A presença de placa visível foi detectada em $44,4 \%$ das crianças e as contagens de Sm foram positivas para $80,3 \%$ da amostra. Ambas variáveis foram 
correlacionadas com uma maior prevalência de cárie e um maior sc médio e foram considerados bons preditores do risco de cárie para a população estudada.

BERKOWITZ ${ }^{12}$ relata que em crianças afetadas pela cárie de mamadeira 50\% dos microorganismos cultiváveis da placa dentária são S mutans. Em contraste, os Sm usualmente compõem menos de $1 \%$ da flora da placa de crianças com baixa atividade de cárie. Caracteriza a cárie da primeira infância como "mutans dependente" e especula que somente crianças infectadas por este microorganismos em tenra idade são consideradas de risco.

FUJIWARA et al. ${ }^{39}$ avaliaram a colonização por Sm e a presença de cárie em crianças japonesas de 0 a 2 anos que viviam em uma região de água não fluoretada. Duas avaliações foram realizadas no intervalo de um ano. Estreptococos não foram detectados em idade inferior a seis meses e foram primeiramente detectados em 7,3\% das crianças entre 7 e 11 meses. A prevalência de Sm foi crescente com a idade, estando presente em $20 \%$ das crianças de 12 a 17 meses, em $30 \%$ das crianças entre 18 e 23 meses, em $43 \%$ das crianças entre 24 e 29 meses e em $61 \%$ das crianças de 30 a 36 meses. O ceos das crianças sem mutans foi significativamente inferior ao de crianças $S m$ positivas $(1,41 \times 9,42$, respectivamente). Após um ano 18\% das crianças sem mutans desenvolveram cárie com um ceos médio de 12,5 enquanto $43,7 \%$ das crianças Sm positivas desenvolveram novas lesões com um ceos médio de 18,4.

Também no Japão TSUBOUCHI et al. ${ }^{113}$ relataram prevalências de cárie em crianças de 18 meses variando de 11\% a 20\% em diferentes estudos nas duas últimas décadas. Destacam o aumento da prevalência particularmente rápido 
a partir do $18^{\circ}$ mês de vida, observando que entre 18 e 36 mese houve um aumento de 5 vezes na prevalência.

\subsection{Avaliação das condições de saúde bucal e do nível de conhecimento de populações obstétricas}

Estudos australianos ${ }^{25,48}$ das décadas de 70 e 80 revelaram altos índices de doenças bucais em gestantes sugerindo a necessidade do cirurgiãodentista como membro integral da equipe pré-natal, diagnosticando e tratando as doenças e instituindo um programa preventivo. JAGO et al. ${ }^{48}$ relataram que $3 \%$ das 314 gestantes avaliadas mostravam-se edêntulas e 13\% usavam algum tipo de prótese. Apenas $16 \%$ das gestantes estavam livres de gengivite, $67 \%$ tinham cálculo, 25\% apresentavam bolsa periodontal em pelo menos um sextante e $8 \%$ em vários sextantes. Em apenas uma gestante não foi diagnosticada presença de cárie, o CPOD médio foi de 15,8, sendo 2,7 dentes cariados. Setenta por cento da amostra necessitava de tratamento restaurador, $5 \%$ de endodontia e $10 \%$ de exodontia. Doze por cento necessitavam de pronto atendimento (urgência) e 7\% tinham dor. Observaram correlação significativa entre o número de dentes cariados e o nível educacional das pacientes, porém não com a renda familiar. Cinqüenta e seis por cento relataram que procuravam por atendimento odontológico somente em caso de dor.

Na mesma região, na década anterior, CHAPMAN et al. ${ }^{25}$ avaliaram o conhecimento sobre saúde bucal, os hábitos de higiene e as necessidades de 
tratamento de 303 gestantes. Cinqüenta e um por cento da amostra relatou a mãe como principal fonte de conhecimentos adquiridos sobre saúde bucal. Quarenta e três por cento acreditavam que a gravidez, por si, era um fator etiológico da cárie, e $13 \%$ concordaram com a expressão "para cada filho um dente". A higiene oral foi classificada como insatisfatória para $75 \%$ das pacientes. Trinta por cento das pacientes haviam sofrido dor de dente durante a gravidez, embora apenas $8 \%$ tenha recebido atendimento odontológico. Encontraram um CPOD médio de 19,1, sendo 2,8 dentes cariados. Cinqüenta e três por cento apresentava-se com gengivite, 18\% com periodontite e $10 \%$ edêntulas. Setenta por cento da amostra necessitava de tratamento restaurador, sendo a metade dos casos considerados urgentes e $22 \%$ necessitavam de exodontia.

PAPP et al. ${ }^{89}$ em 1990, na Hungria, avaliaram o estado de saúde bucal de 57 pacientes durante o período gestacional. A prevalência de cárie e gengivite foi de $98,25 \%$ e $96,5 \%$, respectivamente.

BAKHMUDOV;BAKHMUDOVA ${ }^{10}$, em estudo recente (2000), examinaram o estado de saúde bucal de 664 gestantes russas e observaram que a necessidade de tratamento restaurador estava presente em $77 \%$ das pacientes com idades entre 17 e 19 anos e em 100\% das pacientes com mais de 35 anos. O número médio de dentes cariados foi de $2,46,50 \%$ delas tinham pelo menos um dente para extração e a qualidade da higiene oral foi classificada como pobre.

As condições de saúde bucal e o nível de infecção por Sm foram determinados em gestantes brasileiras $28,30,79,84,90,92,93,97,101,124$. Dados específicos sobre usuárias da rede de saúde pública da cidade de Bauru ${ }^{79,101,124}$ revelaram a 
necessidade premente de um programa de adequação bucal direcionado às gestantes.

SILVEIRA et al. ${ }^{101}$ avaliando 50 pacientes encontraram um índice CPOS médio de 37 (5 a 114), sendo que o componente cariado variou de 1 a 49 superfícies (média 9,72). Apenas $16 \%$ das gestantes tinham todos os dentes. Noventa e seis por cento das pacientes foram diagnosticadas como Sm positivas, $68 \%$ apresentaram níveis salivares de $\mathrm{Sm}$ superiores a $10^{5} \mathrm{UFC} / \mathrm{ml}$, sendo que destas, $8(16 \%)$ tinham valores superiores a $10^{6} \mathrm{UFC} / \mathrm{ml}$.

ZANATA et al. ${ }^{124}$, avaliaram clinicamente a condição de saúde bucal de 50 gestantes, também usuárias da rede publica de saúde, seguindo os critérios preconizados pela Organização Mundial de Saúde (OMS). Foi detectado um CPOD médio de 12,5. Este índice alterourse com a idade, tendo sido observado um aumento de $250 \%$ para a faixa etária maior de 35 anos quando comparada à faixa mais jovem (13 a 18 anos). Nas faixas mais jovens predominou o componente cariado (média 3,16 dentes) e na faixa superior a 35 anos predominou 0 componente perdido (média de 11,66 dentes). Quarenta e um por cento das gestantes com menos de 18 anos apresentavam alguma perda dentária, e 50\% das gestantes queixavam-se de dor. Com relação ao estado periodontal, a higidez de todos os sextantes foi observada em $4 \%$ da amostra. Os procedimentos educativos associados à remoção de placa e tártaro supririam a necessidade de tratamento de $100 \%, 87,5 \%$ e $66,7 \%$ do grupo estudado segundo as faixas etárias de 13 a 18, 19 a 34 e mais de 35 anos.

MENINO ${ }^{79}$ em 1995, avaliou, através de questionários, o nível de conhecimento em relação à própria saúde bucal e a da criança entrevistando 150 
gestantes de baixa renda e pouca escolaridade. Ressaltou em seu trabalho a importância do estabelecimento de hábitos pela mãe durante a infância e a receptividade a novos conhecimentos na fase gestacional. Constatou que $91 \%$ das gestantes reconheciam a cárie como problema de saúde, porém, desconheciam sua etiologia. Para $41 \%$ das entrevistadas a perda dos dentes foi considerado um fato implícito ao envelhecimento e, 44\% concordaram com a afirmação de que a gravidez enfraquece os dentes. Oitenta e dois por cento não haviam ido ao dentista durante a gestação, por não sentirem dor ou por terem medo de prejudicar o bebê (45\%). Quarenta e três por cento relataram sangramento gengival, porém não procuraram tratamento. Quinze por cento das gestantes que procuraram atendimento odontológico foram recusadas pelo cirurgião-dentista. Com relação ao futuro bebê, $72 \%$ intencionavam adoçar a mamadeira, 95\% consideraram o uso da pasta de dentes essencial na escovação, porém, o momento de se iniciar a higiene bucal e a época da primeira visita ao dentista foram mal definidos pelo grupo.

COZZUPOL ${ }^{30}$ na década de 70 estudou os fatores que influem sobre a conduta da gestante frente ao problema da assistência odontológica no serviço pré-natal. A pesquisa constituiu-se em um estudo de campo ("survey") realizado com 170 gestantes usuárias da entidade assistencial Amparo Maternal que atendia a cerca de $10 \%$ da população de parturientes de baixo nível sócio-econômico da grande São Paulo. A autora observou que o problema odontológico da gestante é encarado como um problema menor dentro da equipe pré-natal. Há resistência da própria gestante em procurar atendimento, e a disponibilidade de serviços odontológicos nas unidades de saúde é deficiente. Das pacientes entrevistadas, $62,4 \%$ não haviam ido ao dentista durante a gestação sendo a principal justificativa o 
fato de não haver sentido dor (28\%), seguido do medo de causar mal ao bebê (17\%) e da impossibilidade financeira (10\%). Doze por cento das pacientes que procuraram atendimento foram recusadas pelo profissional. Houve uma nítida preferência pelo tratamento exodôntico entre as gestantes e $89 \%$ das entrevistadas declararam algum tipo de receio de se submeter à intervenção odontológica.

ROCHA 92 entrevistou 304 gestantes de baixo nível sócio-econômico e pouca escolaridade da região de Salvador, Bahia. Observou que $62 \%$ das entrevistadas consideraram a perda dos dentes permanentes inevitável, 97,4\% disseram que os problemas bucais (cárie) não afetavam a saúde geral, 83\% não haviam procurado o dentista durante a gestação, $47 \%$ tinham medo de que o tratamento prejudicasse o bebê. $\mathrm{O}$ atendimento odontológico de emergência foi o mais freqüente. Com relação ao futuro bebê, 93,6\% intencionavam adoçar a mamadeira e $79,3 \%$ acreditavam na não necessidade de prevenir ou tratar a cárie na dentição decídua por ser esta temporária.

SCAVUZZP' ${ }^{97}$ avaliou a condição de saúde bucal de 204 gestantes da cidade de Salvador, Bahia, através dos índices CPOD e ICNTP. Investigou também a percepção do grupo quanto à assistência odontológica durante a gravidez. Observou um CPOD médio de 9,71, sendo que 41,2\% dos dentes foram diagnosticados como cariados, e 9,1\% estavam com extração indicada. Aproximadamente $87 \%$ das gestante foram classificadas como cárie ativas. Noventa e cinco por cento apresentavam alguma alteração periodontal, sendo que $73,5 \%$ das pacientes necessitavam de remoção de cálculo em pelo menos um sextante. Apesar das necessidades de tratamento observadas, apenas $7,4 \%$ das entrevistadas procuraram atendimento odontológico, pois constatou-se no grupo a crença de que a 
mulher grávida não pode ir ao dentista. A autora identificou um baixo nível de conhecimento sobre saúde bucal e evidenciou disposição do grupo em adquirir novos conhecimentos sobre o assunto.

Em trabalho publicado em 1996, NASCIMENTO; LOPES ${ }^{84}$ enfocaram os problemas odontológicos encontrados em 40 adolescentes grávidas da região central do Brasil. O interesse por este grupo, segundo os autores, é decorrente de uma somatória de variáveis que favorecem o estabelecimento de doenças como a cárie e a gengivite em gestantes adolescentes (12 a 18 anos): dentes permanentes recém irrompidos, alterações hormonais decorrentes da puberdade e da gestação, alterações da dieta, negligência da higiene bucal, problemas emocionais, hiperacidez bucal. Através da aplicação de questionários constataram uma dieta totalmente descontrolada neste grupo, baixo nível de conhecimento sobre saúde bucal, prejuízo da higiene bucal durante a gestação devido a náuseas e vômitos (42,5\%). Através da análise do fluxo salivar e da capacidade tampão da saliva concluíram que o primeiro manteve-se inalterado e um pH ligeiramente mais ácido $(5,5)$ foi encontrado em $35 \%$ das gestantes e em $2,5 \%$ do grupo controle de mulheres adultas não grávidas.

ROSELL; MONTANDON-POMPEU; VALSECKI Jr.93, em 1999, fizeram o registro da prevalência, severidade e necessidades básicas de tratamento da doença periodontal em 41 gestantes com idades entre 16 e 37 anos através do índice de registro periodontal simplificado. Observaram que 100\% das gestantes necessitavam de algum tipo de tratamento periodontal. Atividades exclusivamente preventivas (remoção de placa e instrução de higiene oral) atenderiam as necessidades de apenas $9,8 \%$ das pacientes. Sessenta e um por cento 
necessitariam também de raspagem e/ou eliminação de margens restauradoras defeituosas e $29,2 \%$ de tratamento cirúrgico. Observaram ainda que a porcentagem de sextantes excluídos devido a perdas dentárias e a presença de bolsas aumentaram com a faixa etária e concluíram que o atendimento às necessidades odontológicas das gestantes deve ser priorizado com o intuito de promover a saúde da paciente e a prevenção primária de seu filho.

PEREZ et al. ${ }^{90}$, utilizando os índices CPOS modificado, placa visível, e sangramento gengival, observaram similaridades no padrão de saúde bucal de 30 pares mãe-filho. Alta atividade de cárie foi detectada em $53 \%$ das mães e $46 \%$ dos filhos. Alto índice de placa em $63 \%$ das mães e $66 \%$ dos filhos e um elevado índice de sangramento gengival foi observado em $40 \%$ das mães e $50 \%$ dos filhos. A coincidência da atividade de cárie entre mãe e filho foi observada em $73 \%$ dos pares estudados. Constataram ainda que a grande maioria das mães (26) não usava fio dental. Vinte e três mães escovavam o dente apenas uma vez ao dia e demoravam menos de um minuto para realização da escovação.

EDWARDS; ROWNTREE ${ }^{36}$ avaliaram o nível de conhecimento sobre saúde bucal de 300 primigestas da região de Sheffield, Reino Unido. Observaram diferença significativa entre o nível de conhecimento sobre saúde e higiene bucal e a prática da última, pois, $60 \%$ apresentavam hábitos de higiene oral insatisfatórios, embora o nível de conhecimento sobre a prática adequada superasse sua aplicação. A falta de preocupação com a dentição decídua e a aceitação apática da perda dos dentes foram pontos de interesse.

$\mathrm{Na}$ Alemanha, GOEPEL et al. ${ }^{40}$, em pesquisa que compreendia 700 gestantes observaram que 357 (51\%) não haviam recebido tratamento odontológico 
durante a gravidez. Porém 57,7\% tinham gengivite. Setenta e um por cento não haviam recebido nenhum tipo de orientação preventiva e $37,4 \%$ das pacientes relataram que sua higiene bucal estava prejudicada devido a náuseas.

Segundo LAINE; PIENIHAKKINEU ${ }^{65}$, LAINE et al. ${ }^{66}$, durante a gestação foi observada uma significativa diminuição na capacidade tampão da saliva e no pH salivar (hiperacidez bucal), sendo ambos rapidamente recuperados dois meses após o parto.

SALVOLINI et al. ${ }^{95}$ confirmam os resultados acima e atribuem um maior risco à cárie durante a gestação devido a alterações na composição da saliva, com diminuição das concentrações de íons calcio e fosfato e aumento de alfa-amilase e ácido siálico.

Segundo COZZUPOL $^{30}$ e SLAVKINS ${ }^{102}$, os fatores adversos à saúde bucal não são particulares ao período de gestação, porém, a negligência neste período causa prejuízos agravados à mãe e pode colocar a saúde do feto em risco. A gravidez pode atuar como fator modificador do organismo favorecendo a agudização de processo infecciosos crônicos. Há uma resposta exacerbada dos tecidos periodontais aos irritantes locais, o que requer intervenção profissional, devendo-se intensificar os cuidados com a higiene bucal, pois as infecções orais (gengivites e periodontites) aumentam significativamente o risco de partos prematuros com bebês de baixo peso ${ }^{31}$. A ausência de saúde periodontal, também favorece a colonização precoce do bebê pelos microorganismos gran-negativos associados a essas patologias, em mecanismo similar ao observado para o $\mathrm{Sm}^{63}$. 
O aspecto comportamental não pode ser esquecido, ao contrário é um dos fatores mais complexos de se trabalhar dentro da etiologia da cárie, porém, de suma importância na sua prevenção.

Diversos autores referenciam a gestação como momento extremamente oportuno para a instituição de medidas educativas $^{18,22,25,26,28,36,48,79,97,112}$ visando o bem estar da gestante e da geração descendente. A participação integral do cirurgião-dentista na equipe pré-natal é sugerida em alguns trabalhos ${ }^{25,30,37,40}$ e recomendada pelo Ministério da Saúde do Brasil desde 1988 em documento que afirma que "as gestantes constituem o grupo ideal para que o processo de aprendizagem se realize e ... todas as gestantes inscritas no programa pré-natal deverão ser agendadas para consulta odontológica de rotina nas unidades de saúde, onde será realizado o exame clínico e elaborado o plano de tratamento a ser desenvolvido durante o pré-natal, devendo-se aproveitar o período de gestação para a introdução de ações educativas em saúde bucal”22.

JAGO et al. $^{48}$ enfatizaram que a atuação sobre mudanças de comportamento e atitudes com relação a saúde seja mais importante durante a gestação do que em qualquer outra fase da vida da mulher.

CHAPMAN et al. ${ }^{25}$ constataram em uma população de 303 gestantes que os pais, e particularmente a mãe, foram referidos como principal fonte de informação sobre saúde bucal indicando que os programas preventivos devem ser direcionados à mãe, principalmente durante a gestação, momento em que a paciente está profundamente preocupada com o bem estar do bebê e com sua própria saúde. Lembram também que esta abordagem preventiva pode ser a primeira recebida pela paciente. Ressaltam que a integração entre ginecologistas e 
dentistas ainda é muito falha. Em sua pesquisa, apenas $8 \%$ dos médicos haviam aconselhado a visita ao dentista, entretanto este profissional deveria estar atento à saúde bucal de sua paciente como fator adjunto ao bem estar geral da gestante e do bebê.

BLINKHORN $^{18}$ investigou a transmissão, da mãe para a criança, de comportamentos de rotina relacionados ao consumo de açúcar e a hábitos de higiene oral. Segundo o autor, os comportamentos aprendidos durante a primeira infância (socialização primária) permanecem profundamente enraizados e são resistentes a mudanças. Intervenções de educação em saúde durante esta fase tem a preocupação primeira de formar hábitos ao invés de tentar mudar rotinas já estabelecidas. Então, os grupos alvo para a educação em saúde são as recém-mães e as gestantes. Denomina esta abordagem como socialização antecipatória, pois as crianças moldam seus comportamentos espelhando-se na família, particularmente na mãe, e adquirem hábitos alimentares e de higiene durante a socialização primária, agindo sem questionar suas ações por aceitarem o padrão instituído como natural.

SARNAT; KAGAN; RAVIV ${ }^{96}$ investigaram o efeito da atitude materna com relação aos cuidados com a própria dentição na prevalência de cárie delas e de seus filhos. Segundo os autores, quanto mais positiva for a atitude da mãe em relação às suas necessidades odontológicas, menor sua prevalência de cárie, e menor a incidência de cárie em seus filhos e melhor a qualidade de higiene oral da criança.

Segundo TSAMTSOURIS; STACK; PADAMSEE ${ }^{112}$ a saúde bucal da criança reflete os padrões de atitudes e comportamentos de seus pais, portanto, 
estes deveriam ser educados antes de terem filhos. Isto destaca a importância de ações educativas durante o período pré-natal atuando beneficamente tanto sobre fatores materno-fetais como posteriormente sobre a criança. Durante a gestação a motivação dos pais é grande e grupos de aconselhamento pré-natais devem ser aproveitados, pois grupos pós-natais são pouco freqüentados. Os autores trabalharam com um grupo de 179 futuros pais de diversos níveis sócio-econômicos. A atuação foi limitada à aplicação de uma palestra de trinta minutos abordando o papel da alimentação, medicamentos e flúor durante o período pré-natal, a prevenção da cárie na primeira infância e orientação de como proceder a correta higiene bucal da gestante e do bebê.

Após 8, 12 e 24 meses SHEIN; TSAMSOURIS; ROVERO 99 avaliaram o impacto da atuação pré-natal questionando os pais sobre os tópicos abordados na palestra de TSAMTSOURIS; STACK; PADAMSEE ${ }^{112}$. Concluíram que, embora a aquiescência (nível de conhecimento) sobre medidas preventivas tenha sido maior para os pais do grupo experimental, uma única abordagem é ineficaz em garantir maior preocupação com a saúde bucal da criança. O reforço constante das orientações é necessário para que mudanças de hábito ocorram. Sugerem o aprimoramento das técnicas de transmissão de conhecimento e a participação efetiva dos meios de comunicação para aumentar a assimilação e motivação dos pais.

KALSBEEK; VERRIPS ${ }^{52}$ investigaram a relação entre medidas preventivas executadas antes da idade de seis anos e a incidência de cárie na dentição permanente com a idade de 15 anos. Consideraram o CPOS nas referidas idades, o uso de flúor sistêmico e a atitude (motivação) da mãe com relação à saúde 
bucal da criança, o que foi julgado pelo dentista quando a criança tinha 2 anos. Das variáveis mencionadas, a atitude materna mostrou-se como o fator mais significativo. Os índices CPOS aos 15 anos de crianças cujas mães foram classificadas como negativas, neutras, positivas ou muito positivas foram respectivamente:18,7; 11,5 ; 7,8 e 2,4

$\mathrm{Na}$ Irlanda do Norte McCABE ; KINIRONS ${ }^{77}$ constataram que na faixa etária de 0 a 2 anos apenas 35\% dos pais haviam levado seus filhos ao dentista, sendo a principal razão alegada a ausência de dor ou de cavidades, o que mostra que, mesmo em países desenvolvidos, uma filosofia preventiva para a primeira infância precisa ser encorajada. Os autores também observaram que a prevalência de cárie estava significativamente associada ao nível educacional da mãe, sendo a prevalência da doença quatro vezes superior para as crianças cujas mães tinham apenas educação básica quando comparadas às crianças cujas mãe haviam completado $03^{\circ}$ grau $(46,8 \% \times 10,6 \%$, respectivamente). Segundo os autores 0 padrão de atendimento odontológico da mãe é refletido nos filhos. Quanto mais freqüentes e regulares são as visitas da mãe ao dentista, maior a probabilidade dela levar o filho menor de 3 anos para uma consulta.

Além das evidentes necessidades de tratamento enfocadas pela literatura em populações obstétricas de diversos países, constata-se que as gestantes têm carência de informações adequadas sobre sua própria saúde oral e de seus futuros bebês. Esse fato é freqüente e correlato com a situação sócioeconômica, sendo mais preocupante em populações de baixa renda e pouco grau de instrução. Este grupo tem seu acesso ao cirurgião-dentista dificultado por barreiras financeiras e culturais, raramente recebendo educação odontológica e 
apresentando um perfil resistente à mudança de atitude/comportamento. Esse quadro coloca os bebês numa situação altamente favorável ao desenvolvimento da cárie precoce da infância ou cárie da primeira infância.

\subsection{Atuação odontológica nos períodos pré e pós- natal}

KÖHLER et al. ${ }^{62}$ em 1982 introduziram um programa preventivo básico em 45 (grupo experimental) de 87 recém-mães pré-selecionadas em função da alta contagem de microorganismos cariogênicos (níveis salivares de Sm superiores a $10^{6}$ UFC / $\mathrm{mL}$ de saliva estimulada). O programa constituiurse em aconselhamento sobre a dieta, instruções sobre higiene oral, profilaxia profissional, fluorterapia (bochechos diários e aplicação de verniz) e escavação em massa (escariação) e selamento provisório. O efeito do tratamento foi monitorado através de contagens microbiológicas para Sm e Lb, mostrando-se efetivo na redução significativa da população bacteriana em $60 \%$ do grupo. As pacientes cujos níveis de infeccção por Sm mostraram-se superiores a $3 \times 10^{5} \mathrm{UFC} / \mathrm{mL}$ de saliva duas semanas após a instituição das medidas básicas foram submetidas a um regime com aplicações tópicas de gel de digluconato de clorexidina $1 \%$ diariamente, por 5 minutos, durante duas semanas, o qual mostrourse efetivo na redução dos níveis de Sm.

Dando continuidade ao seu estudo KÖHLER; BRATTHAL; KRASSP1 estenderam o monitoramento microbiológico por um período de 36 meses, avaliando quadrimestralmente a contagem de Sm das mães e procurando detectar a primoinfecção dos bebês a partir do $15^{\circ}$ mês de vida. O programa preventivo e/ou regime 
com clorexidina manteve-se através do estudo a menos que houvesse detecção de Sm no bebê ou os níveis de Sm ra mãe não pudessem ser reduzidos a valores inferiores a $3 \times 10^{5}$ UFC. Em todas as coletas a prevalência de bebês Sm positivos foi significativamente inferior no grupo experimental. Em ambos grupos a prevalência aumentou com a idade.

Aos 23 meses $16 \%$ das crianças do grupo experimental e $45 \%$ das crianças do grupo controle mostraram-se Sm positivas. Aos 36 meses esta prevalência atingiu 35\% e $65 \%$ das crianças dos respectivos grupos. No grupo controle, que não recebeu nenhum tipo de medida preventiva, a maioria das mães permaneceram com contagens de Sm superiores a $10^{6}$ UFC. No grupo experimental, a maioria dos bebês contaminados eram filhos de mães com altas contagens de Sm, ou seja que não responderam bem ao tratamento preventivo e tiveram que ser submetidas ao regime com clorexidina, porém também foram diagnosticados bebês contaminados de mães com baixas contagens. Os autores concluem que a diminuição do nível de infecção por Sm na mães pode inibir ou retardar a primoinfecção de seus bebês.

KÖHLER; ANDRÉEN; JONSSON ${ }^{59}$ em 1984 publicaram os dados referentes a prevalência de cárie aos 3 anos das crianças pertencentes a este estudo longitudinal. A prevalência foi de $43 \%$ para o grupo controle , e $16 \%$ para o grupo experimental, sendo observada diferença estatística entre os grupos. Cinqüenta e um por cento das crianças Sm positivas apresentaram cárie contra 3\% das crianças diagnosticadas como Sm negativas. Quanto mais precoce a infecção por Sm, mais significativa foi a experiência de cárie: 77\% das crianças Sm positivas com a idade de 15 meses desenvolveram cárie, o mesmo ocorrendo com $42 \%$ das 
crianças Sm positivas com a idade de 23 meses e $33 \%$ das crianças Sm positivas com 36 meses. A aplicação de um questionário de dieta de 3 dias para os bebês não revelou diferença significativa no padrão de ingestão de sacarose entre os grupos.

O programa preventivo instituído por KÖHLER e colaboradores ${ }^{59,61,62}$ foi descontinuado com a idade de 36 meses, entretanto KÖHLER ;ANDRÉEN ${ }^{58}$ avaliaram o efeito desta abordagem precoce na experiência de cárie e na prevalência de microorganismos cariogênicos das crianças com a idade de 7 anos (n =58). Ambas variáveis foram significativamente mais pronunciadas nas crianças do grupo controle, onde $95 \%$ estavam colonizadas por Sm e 9\% estavam livres de cárie. O ceos médio observado foi 8,6 e $48 \%$ das crianças cárie-ativas apresentavam um ceos $>$ 9. No grupo experimental, a prevalência de crianças Sm positivas foi $46 \%$, 23\% estavam livres de cárie, o ceos médio foi 5,2 e 19\% das crianças cárie-ativas apresentaram um ceos $>9$.

A despeito do grupo a que pertenciam, as crianças colonizadas antes da idade de 2 anos apresentaram as mais expressivas experiências de cárie e as mais altas contagens de Sm. Todas haviam sido acometidas pela cárie, com um ceos médio de 9,4. Valores significativamente menores foram observados para as crianças colonizadas após 3 anos de idade: prevalência de cárie de $83 \%$ e ceos médio de 4,6.

Os autores concluem que medidas preventivas direcionadas às mães durante o período da erupção da dentição decídua são eficazes em reduzir a experiência futura de cárie de seus filhos.

Em 1992 TENOVUO et al. ${ }^{108}$, na Finlândia, acompanharam 151 crianças entre as idades de 1 e 4 anos. Com a idade de 1 ano as mães das crianças 
foram divididas em três grupos com base na contagem de Sm na saliva materna. No grupo 1 as mães possuíam mais de $10^{5}$ UFC / $\mathrm{mL}$ de saliva estimulada e foram submetidas a regimes semestrais de aplicação tópica de gel de clorexidina $1 \%$ e fluoreto de sódio $0,2 \%$. O segundo grupo, denominado controle 1 era composto por mães também com níveis de $\mathrm{Sm}$ superiores a $10^{5}$, porém não receberam uso de anti-micobianos. O grupo controle 2 era composto por mães com baixas contagens de Sm.

Com as idades de 2, 3 e 4 anos as crianças foram avaliadas quanto à prevalência de Sm e à experiência de cárie. A diferenças observadas entre os grupos no que se refere à colonização por Sm não foram significantes. Independentemente do grupo, observourse forte associação entre a detecção de Sm, sua precocidade e a subsequente experiência de cárie. A prevalência de crianças com cárie e o ceod médio foram inferiores para o grupo controle 2. A prevalência de crianças com cárie não diferiu entre os grupos experimental e controle 1, porém o ceod médio foi maior para o grupo controle 1.

Iniciando uma seqüência de estudos com o objetivo de se prevenir a transmissão de Sm da mãe para o bebê, WRIGHT et al. ${ }^{123}$ avaliaram o efeito do tratamento restaurador convencional sobre populações bacterianas da cavidade oral, incluindo $\mathrm{Sm}$ e Lb. Foram selecionadas 52 gestantes com contagens de Sm superiores a 25.000 UFC / mL de saliva não estimulada. Logo após o nascimento do bebê, as pacientes receberam instruções de higiene oral e foram submetidas ao tratamento restaurador (amálgama, esina, restaurações indiretas e extrações). O monitoramento microbiológico foi feito antes, durante e após o tratamento restaurador, o qual durou em média 90 dias. Observourse redução significativa na 
contagens de microorganismos cariogênicos, principalmente com relação aos Lb. Entretanto o efeito do tratamento foi transitório e de curta duração, com a recolonização por Sm atingindo valores próximos aos iniciais em aproximadamente dois meses.

Dando continuidade ao estudo de WRIGHT et al. ${ }^{108}$, DASANAYAKE et al. ${ }^{32}$ dividiram o grupo de mães em controle $(n=25)$ e experimental $(n=23)$. No grupo experimental realizourse o selamento das fissuras não restauradas e no momento da erupção do primeiro dente do bebê foram feitas nas mães profilaxia e aplicação tópica de uma solução a base de iodeto de potássio e fluoreto de sódio por 5 minutos, em dias alternados durante duas semanas. O efeito do tratamento foi monitorado microbiologicamente. Imediatamente observourse uma redução significativa na população de Sm e Lb (70\% e 45\%, respectivamente). As contagens pós tratamento foram feitas a cada 3 meses até que o bebê completasse 3 anos e, em nenhuma delas, observourse diferença significativa na contagem de Sm entre os grupos.

A aquisição de Sm pelos bebês também não diferiu entre os grupos, contudo as crianças do grupo experimental foram colonizadas mais precocemente. Aos dois anos a prevalência de cárie foi de $17 \%$ para o grupo experimental e $4 \%$ para o grupo controle, e aos 3 anos de $30 \%$ e $16 \%$ resprectivamente. Os autores concluem que o regime antimicrobiano teve efeito transitório, de curta duração sobre a população bacteriana da cavidade bucal da mãe, porém não influenciou, estatisticamente, a aquisição de Sm e a experiência de cárie dos bebês.

BRAMBILLA et al. $^{20}$ em 1998 avaliaram o efeito de um programa preventivo mínimo iniciado durante a gestação na transmissão de Sm da mãe para o 
filho. Selecionaram 65 gestantes no primeiro trimestre de gravidez com contagens de $\mathrm{Sm}>10^{5}$ UFC / $\mathrm{mL}$ de saliva não estimulada, em uma região com baixo conteúdo de flúor na água, e dividiram-nas em grupo controle $(n=32)$ e experimental $(n=33)$. Ambos os grupos receberam uma sessão de aconselhamento sobre dieta e instruções sobre higiene oral e profilaxia profissional e fizeram uso de flúor sistêmico (1 mg / dia) do sexto ao nono mês de gestação. Adicionalmente no grupo experimental instituiu-se um regime de bochechos diários com soluções de flúor $0,05 \%$ e clorexidina $0,12 \%$ em três ciclos de 20 dias de uso seguidos de 10 dias de dencanso. Nenhuma paciente recebeu tratamento restaurador e o número médio de dentes cariados foi 1,4.

As contagens de Sm foram feitas durante o tratamento e $6,12,18, \mathrm{e} 24$ meses após o nascimento do bebê. Sessenta pacientes completaram o estudo. Não houve relatos de efeitos adversos.

Observou-se diferença estatística entre os grupos a partir do fim do período de tratamento (nono mês de gestação) e esta manteve-se até o fim do estudo (30 meses), sendo que as contagens de Sm no grupo experimental diminuiram cada vez mais, até valores inferiores a $10^{5}$ UFC considerado como limite de risco, 12 meses após o fim do tratamento. Em ambos os grupos a porcentagens de crianças infectadas por Sm foi crescente com a idade. A prevalência de crianças Sm positiva aos 30 meses diferiu entre os grupos sendo de $83 \%$ para o grupo controle e $48 \%$ para o experimental. O momento da primo-infecção foi em torno de 18 meses para o controle e 22 meses para o experimental.

GUNAY et $\mathrm{al}^{44}$ em 1998 publicaram os resultados parciais de um estudo longitudinal tri-fásico envolvendo inicialmente 86 gestantes de diversas 
classes sociais que participavam do programa pré-natal de um hospital em Hannover, Alemanha. A primeira fase do estudo desenvolveurse durante a gestação, sendo que no $4^{\circ}$ mês de gravidez foram diagnosticadas as condições iniciais da amostra: contagem de Sm, índice de placa proximal, avaliação da condição periodontal através do ICNTP e avaliação da experiência de cárie através do índice CPOS. Nesta oportunidade as pacientes receberam uma abordagem preventiva individualizada envolvendo instruções sobre higiene oral, profilaxia profissional, aplicação de verniz com flúor, bochecho com solução a base de clorexidina, aconselhamento sobre dieta e informações sobre a etiologia, transmissão e prevenção da cárie e das doenças periodontais. Na evidência de necessidade restauradora a paciente era aconselhada a procurar seu dentista. No oitavo mês de gestação a abordagem preventiva foi repetida.

A segunda fase do estudo iniciou quando os bebês tinham 6 meses e continuou até que completassem 36 meses, contando com 54 participantes que eram chamadas a cada 6 meses para receber os cuidados preventivos e para atualização dos parâmetros clínicos CPOS, índice de placa e contagem de Sm. Novas informações, direcionadas aos cuidados com a alimentação e higiene bucal das crianças foram oferecidas. O grupo controle constituiu-se de 65 crianças de 3 anos de idade selecionadas aleatoriamente em escolas de educação infantil.

A terceira fase do estudo avaliou o efeito residual da abordagem preventiva, suspensa com a idade de 36 meses, nas mães e nas crianças com idades de 4, 5 e 6 anos (ainda em andamento).

Aos 3 anos todas as crianças do grupo experimental estavam livres de cárie, apresentaram uma higiene oral considerada ótima e contagens de Sm 
inferiores a $10^{3} \mathrm{UFC} / \mathrm{mL}$ de saliva. No grupo controle a prevalência de cárie foi de 18,5\%, com um ceos médio de 4,5. Trinta e cinco por cento das crianças apresentavam higiene oral insatisfatória, e $62,5 \%$ delas apresentavam mais de $10^{3}$ UFC / $\mathrm{mL}$ de saliva. Todas as diferenças foram estatisticamente significantes. Os efeitos benéficos da abordagem preventiva foram constatados após 1 ano da interrupção do estudo, pois, novamente, todos os parâmetros foram estatisticamente melhores para as crianças do grupo experimental.

Com relação às mães, observou-se melhora significativa no padrão de higiene bucal e na contagem de Sm comparando-se os valores do "baseline" com os obtidos ao final do estudo. No "baseline" aproximadamente 35\% das gestantes apresentavam higiene bucal satisfatória, e no final do estudo quase $80 \%$ das mães atingiram esta condição. Contagens de $\mathrm{Sm}$ superiores a $10^{6}$ UFC / $\mathrm{mL}$ de saliva foram encontradas em aproximadamente $40 \%$ das pacientes no início do estudo, porcentagem que foi reduzida a $22 \%$ na última avaliação. Apenas duas pacientes desenvolveram novas lesões ao longo do estudo.

SÖDERLING et al $^{104}$ em 2000, com o objetivo de monitorar longitudinalmente (24 meses) a transmissão de $S m$ da mãe para o bebê, desenvolveram um estudo com 169 gestantes com contagens de Sm > $10^{5}$ UFC / $\mathrm{mL}$ de saliva estimulada. As pacientes foram divididas em três grupos que receberam tratamento com xilitol - grupo 1 (gomas de mascar duas a três vezes ao dia a partir do terceiro mês pós-parto); aplicações semestrais de verniz com clorexidina (grupo 2 ) ou com flúor (grupo 3). Medidas preventivas e restauradoras básicas foram recebidas por todos os grupos através dos programas pré e pósnatais gratuitos existentes em centros de saúde da Finlândia. Os pares mãe-filho 
foram monitorados microbiologicamente e examinados clinicamente (CPOD e número de dentes decíduos erupcionados) quando as crianças tinham idades de 6 , 12 e 24 meses.

Não houve diferença entre os níveis de Sm das mães dos 3 grupos em nenhuma avaliação. As altas contagens de Sm observadas no início do estudo se mantiveram em cerca de $80 \%$ das pacientes, independente do grupo. Porém, a prevalência de crianças Sm positivas com a idade de 2 anos foi significativamente inferior para o grupo $1(9,7 \%)$ quando comparado aos grupos $2(28,6 \%)$ e $3(48,5 \%)$, os quais não diferiram entre si, sugerindo que o consumo habitual de xilitol pelas mães durante o período de erupção da dentição decídua de seus filhos esteja associado a uma significativa redução na transmissão materna de Sm.

Abordando o fator imunidade, AALTONEN, et $\mathrm{al}^{3}$. estudando 36 crianças, divididas em dois grupos, que apresentavam comportamentos extremos com relação à freqüência de contato salivar com a mãe no primeiro ano de vida, constataram a conferência de imunidade à cárie através da indução de anticorpos séricos anti-Sm na criança a partir da presença de $S m$ na saliva da mãe. Observaram um nível de IgG anti-Sm significativamente maior no grupo de crianças que tinham contato salivar freqüente com a mãe. Embora não tenha sido identificada diferença estatística entre os níveis salivares de Sm e a experiência de cárie dos grupos, os autores sugerem que tenha havido uma ação protetora das imunoglobulinas no grupo de contato freqüente, "compensando" o maior desafio cariogênico a que foi submetido este grupo devido às inoculações de Sm, 
igualando a experiência de cárie "compensação imunológica a um desafio cariogênico maior".

Em 1988, AALTONEN; TENOVUO; LEHTONEN² investigaram a relação entre o tratamento odontológico durante a gestação e a produção de anticorpos séricos e secretores contra Sm nos filhos, correlacionando este fato com a prevalência de cárie nas crianças. Cinqüenta gestantes foram divididas em dois grupos, de acordo com a experiência de cárie, buscando-se formar grupos homogêneos. Houve maior produção de anticorpos no grupo de crianças cujas mães não receberam tratamento odontológico, o que pode ter ocorrido devido a variações na passagem transplacentária de informações imunológicas ou devido a passagem de Sm via saliva, no pós-parto, ou a ambos. Sugerem que o tratamento odontológico seja postergado para o momento da erupção da dentição decídua, momento no qual a alta contagem de Sm na saliva materna oferece risco real ao bebê.

AALTONEN et al em 1990 observaram que em um período de 5 anos estudando a experiência de cárie de 67 pares mãe-filho houve correlação positiva entre a experiência de cárie materna e a das crianças. Altas concentrações de Sm na saliva materna também induziram a produção de uma maior concentração de anticorpos nas crianças, havendo ainda a interação de fatores comportamentais (dieta e contato salivar freqüente) sobre o sucesso de implantação. Este modelo de transmissão explicaria os casos de filhos de mães cárie ativas sem cárie. 
AALTONEN ${ }^{1}$ faz um resumo de seus achados concluindo que, a parte do consumo de açúcar, altas contagens de Sm na saliva materna são um fator de risco para criança, pois a quantidade de células disponíveis para a implantação é importante, porém a freqüência de contato é um fator modificador. Tanto a alta atividade de cárie com a presença de contatos salivares freqüentes mostraram-se associados com uma maior produção de anticorpos nas crianças. Ou seja, o maior desafio cariogênico é compensado por uma resposta imune potencializada nestas crianças. 
3 - Proposi çã o 


\section{3 - PROPOSIÇÃO}

O objetivo deste estudo foi analisar clinicamente a efetividade de um programa de saúde bucal iniciado durante a gestação, em primigestas cárie-ativas, sobre a atividade de cárie destas pacientes (mães), e sobre a incidência de lesões em seus filhos até a idade de dois anos. Procurou-se avaliar se:

1: O programa seria eficaz em alterar o grau de exposição das mães a reconhecidos fatores de risco (acúmulo de placa, dieta desequilibrada, presença de cavidades abertas) contribuindo com a sua saúde bucal e com a prevenção primária de seus filhos.

2: O tipo de abordagem direcionada à mãe estaria correlacionado positivamente ao efeito preve ntivo sobre o seu filho

3: Haveria correlação positiva entre a atividade de cárie da mãe e do seu filho. 
4 - Materiais
e Métodos 


\section{4 - MATERIAIS E MÉTODOS}

\subsection{Seleção da amostra (período de abril a junho de 1997).}

Obteve-se primeiramente a autorização da Secretaria Municipal de Saúde para realização deste Programa nas Unidades de Saúde. Os prontuários médicos das gestantes usuárias do atendimento pré-natal da Unidade foram levantados uma um, manualmente, pois não há informatização dos dados. Através das fichas obstétricas identificou-se as gestantes primíparas e estas foram convocadas via correio para comparecerem à Unidade para seleção de atendimento odontológico.

Após explicação oral dos objetivos do Programa ao grupo, as pacientes interessadas foram examinadas clinicamente no consultório da Unidade, utilizandose espelho e sonda, para detecção de lesões ativas de cárie. Este primeiro exame seletivo foi feito sem escovação ou profilaxia prévia, procurando-se detectar lesões evidentes.

\subsubsection{Critérios}

Foram pré-selecionadas em nove Unidades de Saúde do Município de Bauru cem pacientes que preenchiam os seguintes requisitos:

- Primigesta

- Primeiro ou segundo trimestre de gestação

- Gestação sem intercorrências

- Detecção de três ou mais lesões de cárie (cavidades) em superfícies lisas

- Não estar recebendo nenhum tipo de atendimento odontológico durante a gestação 


\subsection{Fase experimental - Etapa Inicial - "Baseline”}

\subsubsection{Termo de consentimento}

Os objetivos e o planejamento das fases do Programa foram detalhadamente explanados, de forma individual, às pacientes que preenchiam os requisitos de seleção, e, estando a gestante de acordo, esta assinava um "termo de consentimento“ (anexo 1) no qual aceitava participar do estudo e cumprir as etapas necessárias para sua conclusão. No caso de ser a paciente menor de dezoito anos requeria-se o consentimento do responsável (anexo 2).

\subsubsection{Obtenção de dados pessoais}

\subsubsection{Identificação (anexo 1)}

\subsubsection{Anamnese (anexo 1)}

Procurou-se identificar se a paciente apresentava algum tipo de transtorno de saúde que desaconselhasse a intervenção odontológica durante o período gestacional.

A autorização escrita do obstetra responsável foi solicitada sempre que necessário.

Os médicos obstetras das Unidades estavam cientes do desenvolvimento do Programa de atenção odontológica à gestante, sendo particularmente informados sobre a etapa cirúrgico-restauradora a que seriam submetidas as pacientes e foram consultados quanto a quaisquer objeções que tivessem. 


\subsubsection{Classificação sócio-econômica (anexo 3)}

A classificação sócio econômica das pacientes foi feita através do critério utilizado pela Associação Brasileira de Anunciantes ${ }^{5}$ (ABA). Este critério fundamenta-se em um sistema de pontuações obtido a partir do nível educacional do chefe da família e da quantidade de bens duráveis na residência.

\subsubsection{Ficha clínica (anexo 1)}

Foram obtidas informações iniciais sobre os hábitos de higiene oral e as condições de saúde bucal das pacientes através de questionamentos diretos e da utilização de índices odontológicos, respectivamente.

Os exames odontológicos foram realizados na seguinte ordem:

\subsubsection{Fluxo salivar e capacidade tampão da saliva}

Este exame foi realizado através da coleta de saliva estimulada seguindo-se as orientações do fabricante do sistema Flux-dent ${ }^{\Uparrow}$. A paciente devia estar em jejum por um período mínimo de uma hora. Era solicitado à paciente que mastigasse um pedaço de borracha durante 1 minuto e então desprezava-se a saliva. A partir daí, coletava-se a saliva produzida durante 5 minutos de mastigação em um "becker" coletor e anotava-se o fluxo salivar da paciente. Um $\mathrm{mL}$ da saliva coletada era misturada a $3 \mathrm{~mL}$ de ácido clorídrico 0,005 Molar em um frasco de vidro e após agitação de 30 segundos e descanso de 10 minutos submergia-se uma fita indicadora de pH na mistura e fazia-se a leitura do pH salivar através da comparação visual entre escalas de cores. 


\subsubsection{Avaliação da condição periodontal - Índice ICNTP}

Utilizou-se o Índice Comunitário de Necessidades de Tratamento Periodontal, ICNTP (Figura 1), para avaliação da saúde e das necessidades de tratamento periodontal dos grupos. Esse índice é preconizado pela Organização Mundial de Saúde $(\mathrm{OMS})^{88}$ para levantamentos comunitários, e baseia-se na obtenção de escores crescentes das necessidades de tratamento, por sextantes ou por indivíduos, em função da situação clínica observada.

Realizou-se a sondagem de dentes índices (16 e17 / 11 / 26 e 27 / 31 / 36 e 37/ 46 e 47), observando-se três indicadores da condição periodontal: presença de sangramento gengival, cálculo e bolsas, que foram divididas em rasas e profundas.

Embora dez dentes tenham sido examinados, apenas seis anotações foram feitas, uma para cada sextante, considerando-se a pior situação encontrada. Para jovens até 19 anos, os segundos molares foram excluídos da sondagem. Um sextante só foi considerado quando havia dois ou mais dentes sem extração indicada. $\mathrm{Na}$ falta dos dentes índices em um sextante, examinavam-se todos $\propto$ dentes remanescentes do sextante e anotava-se a pior condição encontrada.

A sonda preconizada pela OMS apresenta uma esfera de $0,5 \mathrm{~mm}$ na ponta e deve ser usada como sensor, sendo inserida com delicadeza no sulco gengival ou bolsa, sem causar desconforto ao paciente. Devem ser examinados seis pontos em cada dente: mésio-vestibular, médio-vestibular e disto-vestibular, e os locais correspondentes da face lingual. 


\begin{tabular}{|lc|}
\hline \multicolumn{2}{|c|}{ Condição observada no exame } \\
Estado periodontal & Necessidade de tratamento \\
\hline $0-$ Hígido & $0-$ Nenhuma \\
\hline 1 - Sangramento & $\mathrm{I}-$ Instruções de higiene oral + profilaxia \\
\hline $2-$ Cálculo & $\mathrm{II}-\mathrm{I}+$ raspagem supra e sub-gengival \\
\hline $3-$ Bolsa de 4 a $5 \mathrm{~mm}$ & $\mathrm{III}-\mathrm{I}+\mathrm{II}+$ tratamento cirúrgico \\
\hline $4-$ Bolsa com $6 \mathrm{~mm}$ ou mais & $\mathrm{III}-\mathrm{I}+\mathrm{II}+$ tratamento cirúrgico \\
\hline $\mathrm{X}$ - Sextante excluído & \\
\hline
\end{tabular}

FIGURA 1 - Índice Comunitário de Necessidades de Tratamento Periodontal

\subsubsection{Performance de higiene do paciente - indice $P H P^{91}$}

Este é um índice simplificado que quantifica a placa em dentes índices previamente corados. Neste estudo utilizourse a fuccina como corante.

Avaliou-se a superfície vestibular dos primeiros molares superiores (16 e 26), e do incisivo central superior direito e inferior esquerdo (11 e 31), e a superfície lingual dos primeiros molares inferiores (36 e 46).

$\mathrm{Na}$ ausência ou impossibilidade de avaliação dos primeiros molares (presença de coroas totais ou faces muito destruídas ou dentes ausentes), estes foram substituídos pelos segundos molares. Caso estes também não pudessem ser avaliados utilizavam-se os terceiros molares. Na ausência de todos os molares o sextante era excluído. Na impossibilidade de avaliação do incisivo indicado 
analisava-se o dente homólogo, se este não estivesse presente excluía-se o sextante da avaliação.

Cada superfície a ser avaliada foi mentalmente dividida longitudinalmente em terços mesial, médio e distal. $\mathrm{O}$ terço médio foi subdividido horizontalmente em porção gengival, média e incisal (ou oclusal). Figura 2. Cada porção avaliada, quando definitivamente corada, recebeu escore 1, quando não, recebeu escore 0 . A soma dos escores de cada porção corresponde ao escore do dente. A média obtida em todos os dente avaliados é denominada índice PHP.

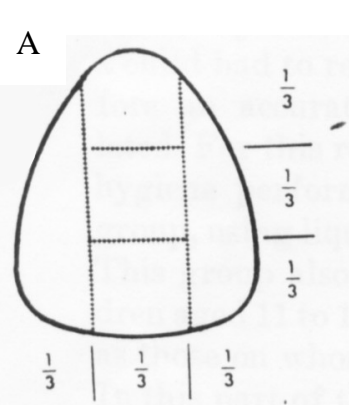

FIGURA 2

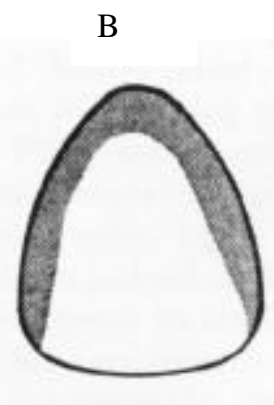

A. Subdivisões da superfície dentária para avaliação do índice PHP (patient hygiene performance); B. Exemplificação de um escore 3; C. Exemplo de um escore 1; D. Exemplo de um escore 4

\subsubsection{Avaliação da condição dentária - Índice CPOS}

Este índice é um indicador global que se refere à cárie dentária através de um sistema de códigos que registram o estado da dentição permanente. O exame clínico foi conduzido com sonda e espelho sob condições de um consultório odontológico, sem respaldo radiográfico, o que subestima a necessidade de tratamento. A extensão desta subestimativa varia com a prevalência da doença na 
população estudada, sendo da ordem de 10 a $15 \%$ em populações com alta prevalência de cárie ${ }^{88}$.

A superfície dentária foi dividida em cinco faces (mesial, distal, vestibular, lingual e oclusal ou incisal) e cada uma delas foi codificada como: Cariada (C), Perdida (P), ou Obturada (O).

O componente obturado deve ser entendido como restaurado. Quando uma superfície apresentava-se restaurada, porém com cárie (primária ou secundária) considerava-se o código $\mathrm{C}$.

O componente cariado $(\mathrm{C})$ referiurse apenas aos estágios mais avançados das lesões de cárie (cavidades).

O diagnóstico das lesões iniciais é complexo ${ }^{47,55}$, por isso, neste estudo, previamente ao exame clínico da condição dentária realizourse profilaxia profissional, pois o padrão de higiene do grupo era insatisfatório e poderia prejudicar o diagnóstico das lesões iniciais.

Os casos clínicos mais expressivos foram documentados através de "slides". Houve a participação de duas examinadoras, calibradas através dos "slides" dos casos clínicos, sob coordenação da orientadora. No caso de divergência no diagnóstico considerava-se a pior situação clínica. 
4.2.3.5. Avaliação da condição dentária - Contagem das lesões de cárie em estágio inicial (desmineralizações ou lesões de mancha branca)

A detecção de lesões incipientes exige uma superfície dentária limpa e seca, demanda maior tempo de exame e maior atenção visual. As lesões incipientes podem localizar-se em superfícies proximais, livres (vestibular e lingual) ou de cicatrículas e fissuras. Para cada área um critério diferente foi necessário para o correto diagnóstico.

Nas regiões de cicatrícula e fissura a detecção visual de manchamentos amarelados ou marrons ao longo da fissura indicava necessidade de investigação adicional. A presença de uma linha esbranquiçada nas paredes laterais da fissura, associada ao diagnóstico tátil de tecido amolecido foi sugestivo de que o processo de cárie estaria se desenvolvendo. O diagnóstico tátil foi feito com uma sonda periodontal, suavemente.

Nas superfícies livres as lesões incipientes foram diagnosticadas visualmente como uma linha esbranquiçada, opaca, no terço gengival do dente, seguindo o contorno do tecido gengival e geralmente coberta com placa bacteriana. A desmineralização podia estar pigmentada. Não foi detectada perda significativa de substância (alteração de contorno). Foi feito o diagnóstico diferencial com lesões inativas ou decorrentes de fluorose.

O acesso às superfícies proximais mostrou-se mais limitado. As lesões apresentavam-se esbranquiçadas e opacas, geralmente próximas ao ponto de contato dos dentes. O uso de separadores mecânicos auxiliou diagnósticos duvidosos. 


\subsection{Fase Experimental - Implementação das medidas preventivas}

Para se selecionar 100 gestantes nas condições desejadas, aproximadamente 430 pacientes foram examinadas. As 100 pacientes foram divididas em dois grupos: Experimental e Controle, aleatoriamente, e foram convocadas a retornar em agosto de 1997 para efetivamente iniciar o Programa.

Oitenta e uma pacientes retornaram, sendo 43 do grupo Experimental e 38 do grupo Controle. Estas pacientes foram submetidas ao seguinte modelo de estudo:

\section{Grupo Experimental:}

A - Abordagem Educativa / Preventiva

- as pacientes recebiam um "kit" de higienização contendo uma escova de dentes Oral B 30, um rolo de fio dental Sanifil de $125 \mathrm{~m}$ e dois tubos de pasta dental Colgate MFP de 90 gramas para cada semestre. Além de um "folder" explicativo (anexo 6).

- as pacientes foram orientadas em grupos pequenos, duas ou três gestantes por vez, ou mesmo individualmente, quanto aos fatores etiológicos da cárie e os meios de prevenção, utilizando-se cartazes, folhetos e modelos de gesso. Enfatizourse o papel da dieta no processo da cárie e o risco de transmissão da doença da mãe para o bebê.

- As instruções de higiene oral foram reforçadas através de uma "escovação interativa" realizada individualmente pela cirurgiã-dentista. Após demarcação da placa bacteriana através de solução de fuccina, as pacientes olhavam em um espelho e observavam as falhas de 
higienização e as áreas de maior acúmulo de placa. A dentista realizava então a escovação afastando os tecidos moles para permitir a visualização das áreas de acesso mais difícil. A técnica de escovação instituída foi a de movimentos circulares, porém movimentações alternativas da escova, por exemplo, no sentido da gengiva para o dente também foram ensinadas para facilitar o procedimento para a gestante.

- O uso do fio dental foi feito em frente ao espelho. Os benefícios do uso do fio dental para o tecido periodontal, principalmente durante a gestação foram insistentemente abordados. A remoção da placa residual foi feita através de profilaxia profissional com taça de borracha e pasta profilática fluoretada.

- Foi distribuído para cada paciente um "questionário de dieta " a ser preenchido durante quatro dias, seguindo-se o trabalho de $\mathrm{KIDD}^{54}$, com o intuito de se ressaltar o consumo de sacarose pela paciente, facilitando o entendimento deste tópico. A paciente notificava sua alimentação durante 4 dias (2 dias da semana, sábado e domingo). Pedia-se às pacientes a identificação de todos os líquidos e alimentos ingeridos, detalhando a adição de açúcar aos mesmos (anexo 4).

B - Adequação Bucal e aplicação tópica de antimicrobianos

- Exodontias e remoção de restos radiculares.

- Realização de curativos endodônticos e encaminhamento das pacientes para tratamento no Departamento de Endodontia da FOB-USP. 
- Remoção de cálculo supra e subgengival através de raspagem com curetas e profilaxia profissional com taças de borracha e pasta profilática IT?.

- Remoção de tecido cariado e selamento das lesões com cimento de ionômero de vidro restaurador de alta viscosidade especificamente desenvolvido para utilização na Técnica Restauradora Atraumática (ART) - Fuji IX .

- Aplicação tópica de solução de iodo associado ao fluoreto de sódio ${ }^{32}$

- Aplicação tópica de flúor fosfato acidulado gel 1,23\% đף

Todos os procedimentos operatórios foram realizados por uma única dentista (R.L.Z.) em uma unidade odontológica móvel completamente equipada, durante a gestação e imediatamente após o parto (15 a 60 dias).

A remoção de tecido cariado foi feita por quadrantes, com intrumentos manuais (colheres de dentina) e rotatório (baixa rotação). O tratamento foi realizado sob isolamento relativo (rolos de algodão e sucção). O acesso às lesões de dentina na região proximal ou com aberturas oclusais estreitas foi feito com pontas diamantadas em alta rotação. A remoção de tecido cariado foi total sempre que possível, ou seja, quando a lesão era pequena era completamente envolvida na forma de contorno do preparo. Em lesões extensas e profundas realizou-se a remoção parcial de tecido cariado, dando particular atenção à junção amelodentinária e paredes circundantes do preparo. Quando necessário foi feita a aplicação de cimento de hidróxido de cálcio, Hidro C, nas paredes de fundo previamente à restauração. 
A utilização de anestésicos locais foi necessária em algumas situações, porém, não foram utilizados como rotina nos procedimentos de dentística. Os preparos foram tão conservativos quanto possível. As cavidades foram lavadas e tratadas conforme as instruções dos fabricantes. O líquido do cimento Fuji IX foi usado como condicionador da dentina . O cimento Fuji IX foi proporcionado e manipulado seguindo-se as instruções do fabricante. A mistura foi inserida nas cavidades usando-se uma espátula de inserção número 1, levando-a às partes profundas do preparo (Figura 3).

Nos preparos Classes I e II o material foi colocado em excesso sobre as fissuras adjacentes e realizourse então pressão digital sobre a restauração, permitindo o escoamento do excesso de material e evitando a inclusão de bolhas de ar. O excesso de material foi removido com um instrumento cortante manual (colher de dentina ou espátula Hollenback) e a superfície da restauração foi protegida com um verniz específico para o produto (Fuji IX Varnish). Após alguns minutos a oclusão foi checada e os ajustes foram feitos com pontas diamantadas de granulação fina. Após o ajuste nova proteção superficial foi feita. Nos preparos Classe II e reconstruções foram empregadas matrizes metálicas e cunhas de madeira e nos preparos Classes III, IV e V, matrizes de poliester.

A aplicação tópica da solução de NaF e iodo foi feita em três sessões, a primeira imediatamente após a profilaxia, a segunda e a terceira aplicações foram feitas após 3 e 5 dias sem profilaxia prévia, ao fim de cada sessão de atendimento da paciente. A solução foi aplicada sob isolamento relativo, por arcadas, utilizandose seringas plásticas e cotonetes e fio dental embebidos na solução. A solução foi 
continuamente aplicada durante 4 minutos sobre a dentição, utilizando-se $3 \mathrm{~mL}$ da mesma. Depois lavava-se a cavidade bucal abundantemente.

A composição da solução usada é a seguinte:

1,0 grama de $\mathrm{KI}$ (iodeto de potássio)

$53,0 \mathrm{~mL}$ de glicerina

1,2 gramas de NaF (fluoreto de sódio)

água para completar $100 \mathrm{~mL}$

A solução foi ajustada a um $\mathrm{pH}$ de 4,5 através de ácido fosfórico $\left(\mathrm{H}_{3} \mathrm{PO}_{4}\right)$ 85\%. A solução foi preparada até duas semanas previamente a sua utilização e armazenada em um vidro ambar sob refrigeração.

Ao fim do tratamento de adequação bucal realizourse aplicação tópica de flúor fosfato acidulado em gel II $^{\text {. }}$.

\section{Grupo Controle:}

A - Abordagem Educativa / Preventiva

- Idêntica a descrita para o grupo Experimental

B - Adequação bucal

- Exodontias e remoção de restos radiculares.

- Realização de curativos endodônticos e encaminhamento das pacientes para tratamento no Departamento de Endodontia da FOBUSP. 
- Remoção de cálculo supra e subgengival através de raspagem com curetas e profilaxia profissional com taça de borracha e pasta

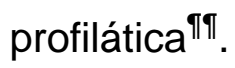

- Remoção de tecido cariado e selamento das lesões com cimento de óxido de zinco e eugenol reforçado IRM nos dentes posteriores (Classes I e II e reconstruções) e com resina composta híbrida (Fill

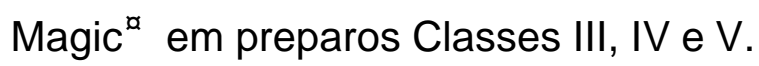

- Não houve aplicação de agentes anti-microbianos.

Inicialmente a intenção era de se restaurar todos os tipos de cavidade com o cimento de óxido de zinco e eugenol, que é o material provisório utilizado na rede pública da cidade de Bauru. Porém, a élha imediata do material (fratura ou queda da restauração) em muitos preparos Classes III, IV e V, e sua aparência antiestética, provocaram rejeições pelas pacientes e então optourse pelo uso da resina.

O cimento de óxido de zinco e eugenol não requer tratamento prévio da dentina. O material foi proporcionado e manipulado conforme as instruções do fabricante. A mistura foi inserida com espátula de inserção número 1 de maneira similar à realizada com o cimento ionomérico nos preparos posteriores, porém, sem o selamento das fissuras. O cimento IRM não requer proteção superficial e a oclusão foi ajustada com brocas de aço esféricas.

Nos preparos a serem restaurados com resina composta, após a remoção de tecido cariado, realizourse o biselamento do ângulo cavo-superficial quando indicado e o procedimento adesivo foi realizado conforme as intruções do fabricante. A fotopolimerização foi realizada incrementalmente nas restaurações extensas. 

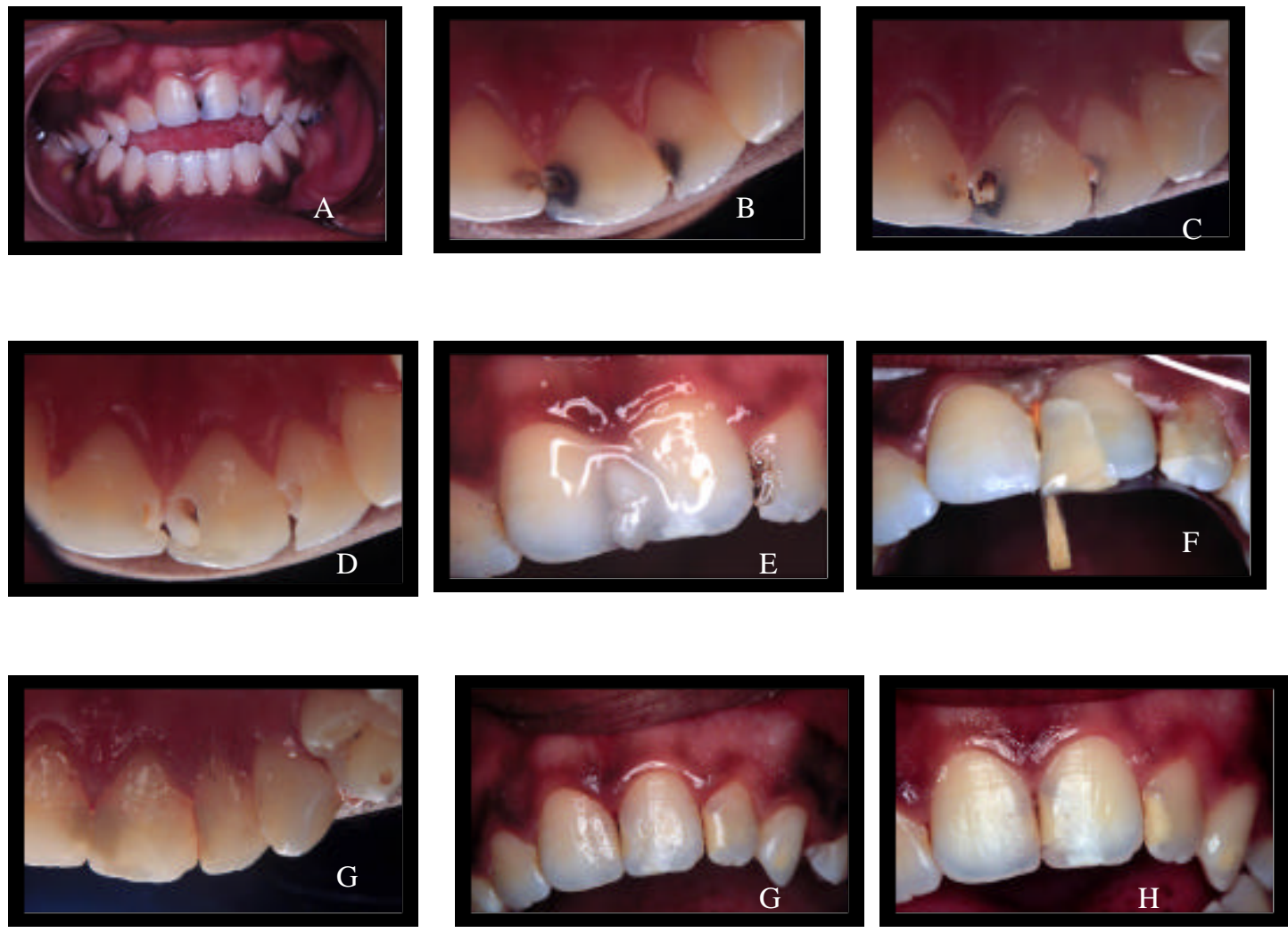

FIGURA 3 - Seqüência clínica do procedimento restaurador executado na adequação bucal do grupo Experimental: A. Caso inicial. B. Vista palatina. C. Remoção parcial de tecido cariado com cortante manual. D. Preparo de cavidade após o uso de instrumento rotatório. E. Limpeza de cavidade com líquido do cimento de ionômero de vidro. F. Inserção do material restaurador. G. Aspecto clínico das restaurações imediatamente após confecção. H. Aspecto clínico das restaurações após 24 meses. 


\subsection{Fase Experimental - Reavaliação de 6 meses}

Nesta etapa os bebês estavam com idades entre 5 e 9 meses e complementou-se a abordagem Educativa / Preventiva enfatizando-se a saúde bucal do bebê:

- Preenchimento da ficha do bebê (anexo 5), através da qual obteve-se informações sobre a saúde geral, hábitos, padrão de amamentação e dieta das crianças.

- Reforço das informações sobre os fatores etiológicos da cárie da primeira infância ratificando o papel da primo-infecção, do uso da mamadeira noturna adoçada e do abuso do aleitamento natural.

- Informações sobre a seqüência de erupção dos dentes decíduos e possíveis intercorrências.

- Instruções sobre a higiene oral dos bebês. Orientourse a limpeza dos dentes (anteriores) e rebordos com gaze (ou fralda) e água filtrada. Foi feita demonstração prática da técnica de higienização pela dentista no próprio bebê, mostrando como posicionar a criança, afastar os tecidos moles e os movimentos de limpeza. Não foi feito uso de macris e as crianças foram acomodadas no colo das mães.

- Exame clínico dos bebês e preenchimento do odontograma (anexo 5).

Atuação sobre as mães:

- Distribuição dos "kits" preventivos 
- Reavaliação dos índices PHP, ICNTP, fluxo salivar e capacidade tampão.

- Nas mães do grupo Experimental realizourse profilaxia com taça de borracha e pasta fluoretada e fio dental. Imediatamente após a profilaxia, aplicou-se a solução de $\mathrm{NaF}-\mathrm{I}_{2}$ conforme formulação preconizada por DASANAYAKE et $\mathrm{al}^{32}$ e seguindo-se o esquema proposto por CAUFIELD; GIBSON ${ }^{23}$.

- Terminado o tratamento com a solução de iodo realizava-se a aplicação tópica de flúor.

\subsection{Fase experimental - Avaliação de 12 meses}

Nesta etapa os bebês estavam com idades entre 12 e 16 meses.

- Atualização da ficha do bebê com relação às alterações de dieta e hábitos de higiene.

- Doação de uma escova dental infantil e introdução da higienização com escova dental e uma quantidade mínima de creme dental.

- Exame clínico (visualização direta e uso do espelho) e utilização do índice ceos, que reduziu-se ao componente sc nos bebês e contagem de lesões iniciais de cárie (desmineralizações).

- O exame clínico foi feito após a escovação dos dentes da criança pela dentista que aproveitava a oportunidade para explicar o procedimento à mãe. 
- Antes da escovação fazia-se o diagnóstico da presença de placa visível na vestibular dos incisivos superiores segundo o método proposto por ALALUSIA E MALMIVIRTA ${ }^{8}$.

Atuação sobre as mães:

- Distribuição dos "kits" de higiene.

- Obtenção do incremento de cárie (cavidades e desmineralizações). Com relação a evolução das manchas brancas era observado se a lesão não estava mais presente ou estava inativa, estava presente e ativa ou se havia cavitado. No caso de formação de cavidade, a mesma era computada no índice CPOS.

- Avaliação do comportamento clínico dos materiais restauradores empregados no procedimento de adequação bucal de ambos os grupos.

- As mães do grupo Experimental foram submetidas à profilaxia, fluorterapia e descontaminação com solução de iodo conforme descrito. Neste grupo realizourse a escariação e selamento das novas cavidades e reparo das restaurações defeituosas.

- No grupo Controle foram realizados procedimentos de urgência.

\subsection{Fase experimental - Avaliação final - 24 meses}

Nesta fase do Projeto as crianças estavam com idades entre 24 e 28 meses. Realizou-se: 
- Atualização da ficha do bebê.

- Doação do "kit " de higienização acrescido da escova infantil.

- Exame clínico, diagnosticando a presença de placa visível, gengivite, lesões de cárie iniciais e manifestas (sc). A gengivite foi diagnosticada através da presença de sangramento espontâneo ou sangramento contínuo após realização da higiene bucal pela dentista.

- Avaliação do incremento de cárie das mães, CPOS e contagem de lesões iniciais.

- Avaliação do comportamento clínico dos materiais restauradores.

- Obtenção dos índices PHP, ICNTP, fluxo e capacidade tampão salivar (CTS).

- Atualização sobre os hábitos de higiene bucal.

- Reparos e substituições de restaurações insatisfatórias em ambos os grupos.

O critério empregado para avaliação dos materiais restauradores está exposto na Tabela 32 .

No grupo Experimental, após obtenção dos dados necessários, o incremento de cavidades e as restaurações insatisfatórias eram restauradas. No grupo Controle este processo mostrou-se muito mais moroso, pois grande parte das restaurações apresentaram-se insatisfatórias (Classes I e II) logo no primeiro ano do estudo. Realizou-se portanto apenas os tratamentos de emergência (dor e risco de exposição pulpar), deixando os retornos por conta do interesse da paciente. 
5 - Resulta dos 


\section{5 - RESULTADOS}

\subsection{GESTANTES}

\subsubsection{Características da amostra}

Com base no critério seletivo descrito, foram pré-selecionadas cem gestantes em dez Unidades de Saúde do município de Bauru. Destas, 81 efetivamente iniciaram o Programa de atenção à saúde bucal, sendo divididas em grupo Controle $(n=38)$ e Experimental $(n=43)$. No decorrer do estudo houve perda da amostra e 64 pacientes finalizaram a pesquisa. Para efeito estatístico foram consideradas as pacientes que se mantiveram no Programa até o fim, participando de todas as etapas intermediárias.

\subsubsection{Idade}

A idade das pacientes variou de 14 a 32 anos, havendo grande concentração de adolescentes, Tabela 1. A idade das pacientes dos grupos Experimental e Controle foi comparada através do Teste $\mathrm{t}$ de Student, não sendo observada diferença estatística, Tabela 2.

TABELA 1. Distribuição da amostra segundo a faixa etária

\begin{tabular}{c|ccc}
\hline Faixa etária & Experimental & Controle & Total \\
\hline 14 a 20 anos & 24 & 24 & $48(75 \%)$ \\
21 a 32 anos & 10 & 06 & $16(25 \%)$ \\
Total & 34 & 30 & $64(100 \%)$ \\
\hline
\end{tabular}


TABELA 2 - Comparação entre as idades dos grupos Experimental e Controle. Teste $t$ de Student

\begin{tabular}{l|cccccc}
\hline & \multicolumn{2}{|c}{ Experimental } & \multicolumn{2}{c}{ Controle } & & \\
& \multicolumn{2}{|c}{$N=34$} & & & \\
& & & & & \\
& Média & Dp & Média & Dp & & \\
\hline \multirow{2}{*}{ Idade } & 19,35 & 4,28 & 18,87 & 2,67 & 0,536 & 0,59 \\
\hline
\end{tabular}

\subsubsection{Classificação sócio-econômica}

As gestantes distribuíram-se entre as classes média (C), baixa (D), e de pobreza absoluta $(\mathbb{E})$. As pacientes das classes $D$ e $E$ foram consideradas em conjunto para efeito de análise estatística devido ao pequeno número de pacientes na classe $E(N=4)$. Não foi observada diferença estatística entre os grupos EX e CT. Tabela 3 .

TABELA 3 - Distribuição da amostra segundo a classe social. Teste $X^{2}$

\begin{tabular}{c|ccccc}
\hline Classe social & Experimental & Controle & Total & $X^{2}$ & $p$ \\
\hline C & $13(38,24 \%)$ & $9(30 \%)$ & $22(34,38 \%)$ & & \\
D + E & $21(61,76 \%)$ & $21(70 \%)$ & $42(65,62 \%)$ & 0,479 & 0,49 \\
Total & 34 & 30 & 64 & & \\
\hline
\end{tabular}




\subsubsection{Nível de escolaridade}

A distribuição da amostra foi feita através de escores estabelecidos em função do grau de instrução da paciente, seguindo-se a pontuação estabelecida pelo critério de classificação sócio-econômica ${ }^{5}$, de forma que o escore1 corresponde ao primeiro ciclo do primeiro grau incompleto; o escore 2 ao primeiro ciclo do primeiro grau completo ( $4^{\mathrm{a}}$ série); o escore 3 corresponde ao primeiro grau completo $\left(8^{\mathrm{a}}\right.$ série); e o escore 4 corresponde ao segundo grau completo ( $3^{\circ}$ colegial). A comparação entre os grupos foi feita através do Teste de Mann-Whitney, não sendo observada diferença estatística entre os grupos EX e CT. Tabela 4.

TABELA 4 - Distribuição da amostra segundo o grau de escolaridade. Comparação entre os grupos - Teste de Mann-Whitney

\begin{tabular}{c|cccc}
\hline Escolaridade & Experimental & Controle & Total & $p$ \\
\hline Escore 1 & 05 & 01 & $06(9,38 \%)$ & \\
Escore 2 & 17 & 22 & $39(60,94 \%)$ & \\
Escore 3 & 10 & 04 & $14(21,86 \%)$ & 0,96 \\
Escore 4 & 02 & 03 & $05(7,82 \%)$ & \\
Total & 34 & 30 & $(100 \%)$ & \\
\hline
\end{tabular}

\subsubsection{Ocupação}

A maioria das pacientes não trabalhava fora de casa (57), cinco trabalhavam como doméstica e duas eram vendedoras. 


\subsubsection{Estado Civil}

A instituição do casamento no seu caráter legal mostrourse pouco freqüente. Foram consideradas casadas todas as pacientes que viviam conjugalmente com um parceiro permanente $(n=42)$. Vinte e duas pacientes eram solteiras.

\subsubsection{Orientação preventiva em saúde bucal recebida previamente}

Trinta e quatro pacientes $(53,13 \%)$ já haviam recebido orientações similares às oferecidas neste estudo, através da escola ou do cirurgião-dentista. Nenhuma gestante relatou a mãe como fonte de informação sobre saúde bucal.

\subsubsection{Ultima visita ao dentista}

Sessenta e quatro por cento das pacientes relataram ter ido ao dentista nos últimos dois anos $(\mathrm{n}=41)$. Dezenove pacientes haviam realizado sua última consulta há mais de três anos e quatro pacientes nunca haviam ido ao dentista.

O motivo da última consulta esteve associado à dor em 33 casos, e à necessidade restauradora (presença de cavidades) em 27 casos. Nenhuma paciente relatou ter ido ao dentista como medida preventiva.

\subsubsection{Hábitos de higiene oral}

Apenas 15 pacientes relataram fazer uso diário do fio dental $(23,44 \%)$. Este hábito de higiene aumentou consideravelmente ao final do Programa, pois 38 pacientes $(59,38 \%)$ relataram o uso diário do fio. A freqüência diária de escovação não se alterou significativamente durante o estudo. Tabela 5. 
TABELA 5. Freqüência de escovação diária relatadas pelas pacientes no início e no final do estudo

\begin{tabular}{c|cccc}
\hline No. Escovações/dia & \multicolumn{2}{c}{$\begin{array}{c}\text { Experimental }(N) \\
\text { "Baseline "/24 meses }\end{array}$} & $\begin{array}{c}\text { Controle }(N) \\
\text { "Baseline" / 24 meses }\end{array}$ \\
\hline 1 ou menos & 03 & 05 & 05 & 04 \\
2 & 09 & 11 & 09 & 13 \\
3 ou mais & 22 & 18 & 16 & 13 \\
Total & 34 & 34 & 30 & 30 \\
\hline
\end{tabular}

5.1.2. Avaliação da condição de saúde bucal das gestantes

5.1.2.1 Atividade de cárie

A experiência/atividade de cárie das pacientes foi avaliada inicialmente através do índice CPOS, e da contagem do número de superfícies com lesões de mancha branca (desmineralizações). Tabela 6 e Figura 4.

As Figuras 5 a 7 ilustram a condição bucal de algumas pacientes no início do estudo. 
TABELA 6. Índice CPOS (média e variação) e número de superfícies com lesões de mancha branca (média e variação) dos grupos Experimental (EX) e Controle (CT) observados no "baseline", $\mathrm{n}=64$

\begin{tabular}{c|ccccc}
\hline & CPOS & Superfícies & Superfícies & Superfícies & Lesões de \\
& & cariadas & perdidas & obturadas & mancha \\
& & & & & branca \\
\hline EX & $36,18(4-113)$ & $14,29(4-41)$ & $13,38(0-95)$ & $8,53(0-33)$ & $4,85(0-17)$ \\
CT & $26,97(6-58)$ & $13,63(5-23)$ & $9,47(0-40)$ & $3,18(0-13)$ & $6,97(0-20)$ \\
Média & $31,86(4-113)$ & $13,98(4-41)$ & $11,64(0-95)$ & $6,25(0-33)$ & $5,94(0-20)$ \\
\hline
\end{tabular}

As variáveis CPOS e SC (superfícies cariadas) e as lesões de mancha branca foram avaliadas estatisticamente através do Teste $T$, comparando-se os grupos Experimental e Controle. O CPOS foi maior para o grupo EX, porém o número de desmineralizações foi superior para o grupo CT, atingindo valores próximos à significância estatísica.Tabela 7.

O componente cariado constituiu $43,88 \%$ da composição do índice CPOS. As cavidades de fissura foram as mais freqüentemente diagnosticadas $(36,6 \%)$ seguidas pelas lesões nas superfícies proximais dos dentes anteriores $(33,03 \%)$ e posteriores (24,57\%). As cavidades em superfície livre (vestibular e lingual) contribuíram com $5,80 \%$ do total de cavidades, porém foram nestas superfícies que as desmineralizações foram diagnosticadas com maior freqüência (58\%), vindo a seguir as superfícies proximais (36\%). 


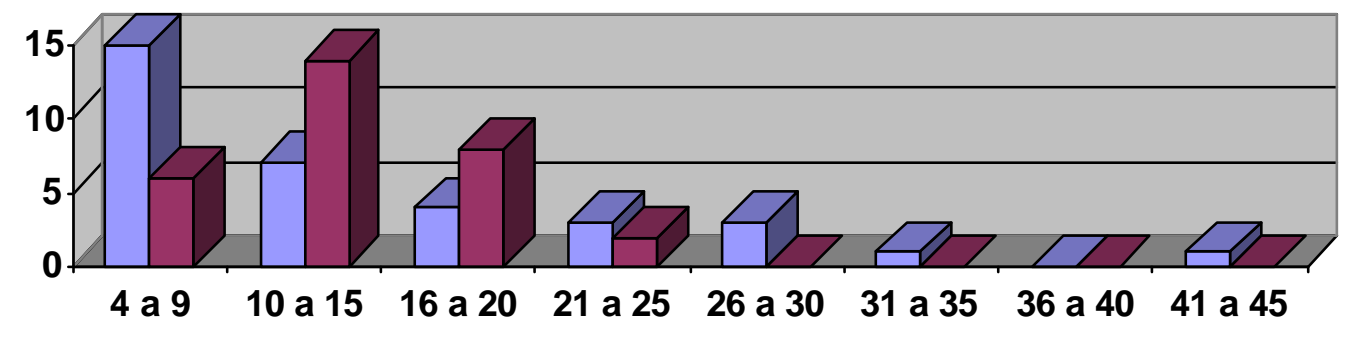

$\square \mathrm{EX} \square \mathrm{CT}$

FIGURA 4 - Distribuição das pacientes dos grupos EX e CT segundo o número de superfícies cavitadas (SC) - Baseline

TABELA 7 - Comparação entre o CPOS, SC e lesões de mancha branca (Imb) dos grupos Experimental e Controle- Teste $t$

\begin{tabular}{c|cccccc}
\hline & \multicolumn{2}{|c}{ Experimental } & \multicolumn{2}{c}{ Controle } & $t$ & $p$ \\
& \multicolumn{2}{c}{$N=34$} & \multicolumn{2}{c}{$N=30$} & \\
& Média & $\mathrm{dp}$ & Média & $\mathrm{dp}$ & & \\
\hline & 36,18 & 23,2 & 26,97 & 12,32 & 1,944 & 0,06 \\
CPOS & 14,3 & 9,18 & 13,63 & 4,66 & 0,355 & 0,72 \\
SC & 4,85 & 4,43 & 6,97 & 5,11 & $-1,937$ & 0,06 \\
\hline Imb & & & & & & \\
\hline
\end{tabular}

- $\quad$ significante se $p<0,05$

Nos períodos de 12 e 24 meses a atividade de cárie das pacientes foi avaliada através do incremento de novas lesões (iniciais e manifestas). Os dados foram analisados através do Teste t comparando-se os grupos EX e CT, Tabela 8 e Figura 8 . 

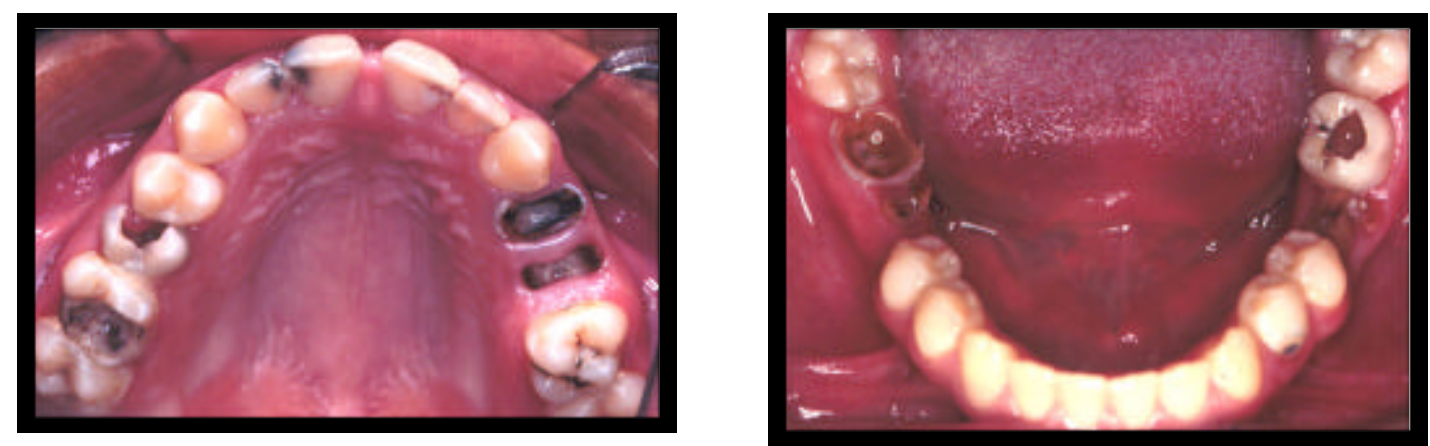

FIGURA 5 - Paciente A. F. L., 18 anos, caso inicial.

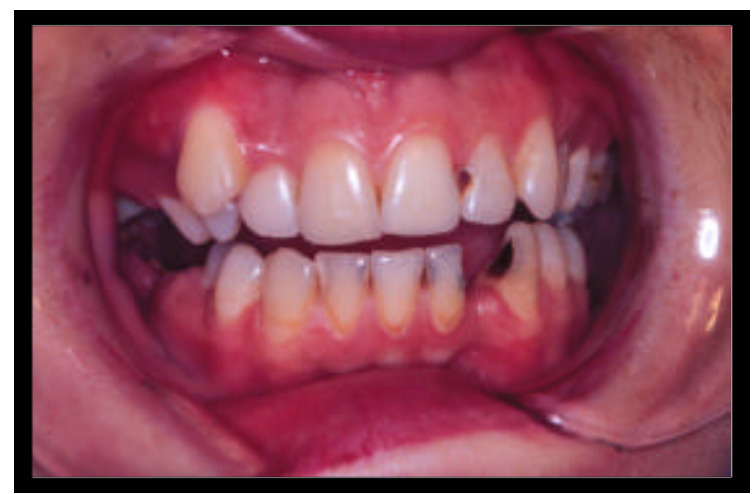

FIGURA 6 - Paciente L. P. R., 17 anos, caso inicial

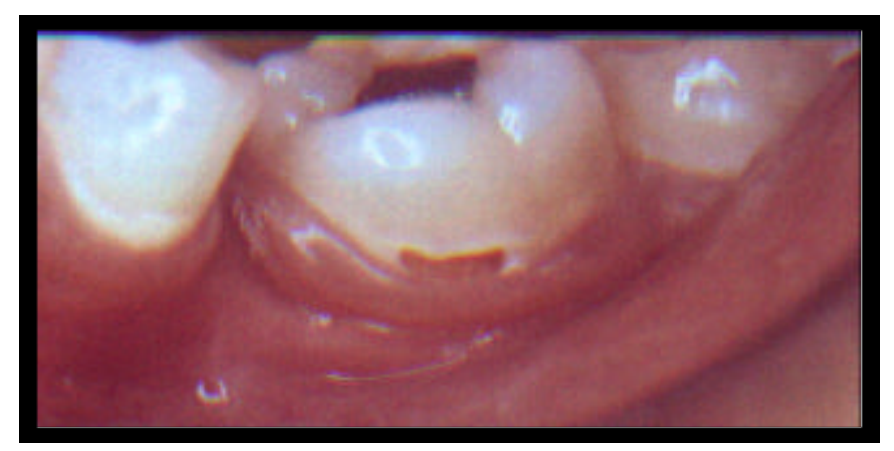

FIGURA 7 - Paciente A. M. G., 17 anos, caso inicial. 


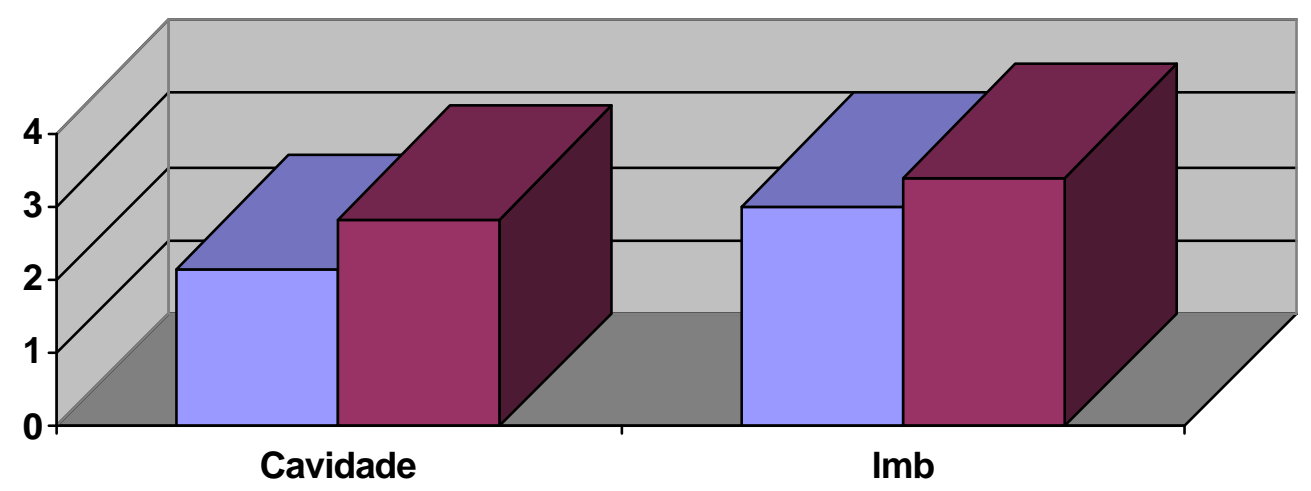

\section{$\square E X \square C T$}

FIGURA 8 - Incremento médio de cárie das pacientes dos grupos Experimental e Controle -24 meses

TABELA 8 - Comparação entre o incremento de cárie (cavidades e lesões de mancha branca) dos grupos Experimental e Controle - Teste $\mathrm{t}-24$ meses

\begin{tabular}{|c|c|c|c|c|c|c|}
\hline & \multicolumn{2}{|c|}{$\begin{array}{c}\text { Experimental } \\
\qquad N=34\end{array}$} & \multicolumn{2}{|c|}{$\begin{array}{l}\text { Controle } \\
N=30\end{array}$} & \multirow[t]{2}{*}{$t$} & \multirow[t]{2}{*}{$p$} \\
\hline & Média & $\mathrm{dp}$ & Média & $\mathrm{dp}$ & & \\
\hline Cavidade & 2,15 & 2,48 & 2,83 & 2,09 & $-1,190$ & 0,24 \\
\hline Imb & 3,00 & 3,25 & 3,40 & 4,30 & $-0,422$ & 0,67 \\
\hline TOTAL & 5,15 & 4,51 & 6,23 & 5,71 & $-0,848$ & 0,40 \\
\hline
\end{tabular}


TABELA 9 - Coeficiente de correlação entre a experiência anterior de cárie (índices CPOS, SC e Imb) e o incremento de novas lesões observado durante o estudo Coeficiente de correlação de Pearson

\begin{tabular}{|c|c|c|}
\hline $\begin{array}{c}\text { Correlação } \\
\text { Inicial x Incremento }\end{array}$ & $r$ & $p$ \\
\hline CPOS x Cavidade & $-0,149$ & 0,240 \\
\hline CPOS $\times$ Imb & 0,055 & 0,662 \\
\hline SC $\times$ Cavidade & 0,224 & 0,075 \\
\hline $\mathrm{SC} \times \operatorname{Imb}$ & 0,323 & 0,800 \\
\hline Imb $\times$ Cavidade & 0,375 & 0,002 * \\
\hline $\operatorname{Imb} \times \operatorname{Imb}$ & 0,017 & 0,893 \\
\hline
\end{tabular}

- Significante se $\mathrm{p}<0,05$

$\mathrm{Na}$ reavaliação de 12 meses, observou-se no grupo EX que sete pacientes não apresentaram incremento de cárie, e nove pacientes apresentaram apenas lesões iniciais (desmineralizações). Com relação às cavidades, foram diagnosticadas 40 novas superfícies com cavitação, sendo 17 em superfície lisa e 23 em fissuras.

No grupo $\mathrm{CT}$, cinco pacientes não apresentaram incremento algum e duas apresentaram apenas desmineralizações. Foram diagnosticadas 54 novas cavidades, sendo 28 em superfície lisa e 26 em fissuras.

Na reavaliação de 24 meses, observoutse que no grupo EX onze pacientes não apresentaram incremento e dez apresentaram apenas lesões inicias. 
Foram diagnosticadas 33 novas superfícies com cavidades, sendo 15 em superfície lisa e 18 em fissuras.

No grupo CT, seis pacientes não apresentaram incremento e oito apresentaram apenas lesões iniciais. Foram diagnosticadas 31 novas cavidades, sendo 18 em superfície lisa e 13 em fissura.

No decorrer de todo o estudo apenas duas pacientes do grupo CT não apresentaram incremento em ambas avaliações.

Como $75 \%$ da amostra tinha menos de 21 anos, durante o estudo muitos dentes terceiros molares erupcionaram. Estes dentes contribuíram significativamente com o incremento de cárie, correspondendo a 23,42\% das novas cavidades e a $29,19 \%$ das lesões iniciais diagnosticadas.

Observou-se correlação significativa entre o incremento de cavidades e um maior número de lesões de mancha branca diagnosticado no "baseline". Tabela 9.

As mesmas variáveis (atividade de cárie inicial e incremento de lesões durante o estudo) foram comparadas entre as mães de bebês cárie-ativos (c/a) e sem cárie (s/c), Tabelas 10, 11 e 12 e Figura 9. 
TABELA 10 - Comparação entre o CPOS, SC e Imb (baseline) das mães cujos filhos apresentaram-se cárie-ativos (Mães-c/a) e das mães de bebês sem cárie (Mães-s/c) - Teste t

\begin{tabular}{|c|c|c|c|c|c|c|}
\hline & \multirow{2}{*}{$\begin{array}{c}\text { Mães s/c } \\
N=49\end{array}$} & & \multicolumn{2}{|c|}{ Mães c/a } & \multirow{3}{*}{$t$} & \multirow{3}{*}{$p$} \\
\hline & & & & & & \\
\hline & Média & $d p$ & Média & $\mathrm{dp}$ & & \\
\hline CPOS & 32,63 & 21,09 & 29,33 & 12,05 & 0,575 & 0,57 \\
\hline SC & 13,86 & 7,96 & 14,40 & 5,15 & $-0,247$ & 0,81 \\
\hline Imb & 5,78 & 5,04 & 6,47 & 4,39 & $-0,478$ & 0,63 \\
\hline
\end{tabular}

TABELA 11 - Comparação entre o incremento de cárie (cavidade e lesões de mancha branca) do grupo de mães cujos filhos apresentaram-se cárie-ativos (Mãesc/a) e das mães de bebês sem cárie (Mães-s/c) - Teste t

\begin{tabular}{c|cccccc}
\hline & \multicolumn{2}{|c}{ Mães-s/c } & \multicolumn{2}{c}{ Mães-c/a } & $t$ & $p$ \\
& \multicolumn{2}{c}{$N=49$} & \multicolumn{2}{c}{$N=15$} & \\
& Média & $\mathrm{dp}$ & Média & $\mathrm{dp}$ & & \\
Cavidade & 2,10 & 2,16 & 3,67 & 2,44 & $-2,379$ & $0,020^{*}$ \\
Imb & 2,43 & 3,14 & 5,67 & 4,58 & $-3,119$ & $0,002^{*}$ \\
TOTAL & 4,53 & 4,03 & 9,33 & 6,51 & $-3,457$ & $0,0009^{*}$ \\
\hline
\end{tabular}




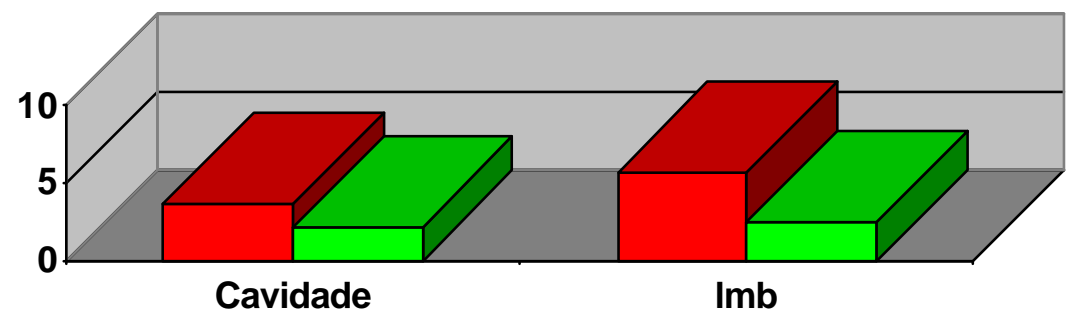

$\square$ mães c/a $\square$ mães s/c

FIGURA 9 - Incremento médio (cavidades e lesões de mancha branca) das mães de bebês sem cárie e cárie-ativos

A diferença significante observada entre os grupos de mães de bebês sem cárie e cárie-ativos deveurse principalmente ao incremento de lesões iniciais e manifestas em superfícies lisas durante o primeiro ano de estudo. Tabela 12.

TABELA 12 - Incremento médio anual das mães de bebês sem cárie (Mães-s/c) e cárie-ativos (Mães-c/a) - Teste t

\begin{tabular}{c|cccccccc}
\hline & \multicolumn{3}{|c}{ Mães-s/c - N=49 } & \multicolumn{5}{c}{ Mães-c/a - $N=15$} \\
\hline & Cavlisa & cavfiss & Imblisa & Imbfiss & Cavlisa & cavfiss & Imblisa & Imbfiss \\
12 & $0,53^{*}$ & 0,69 & $1,16^{*}$ & 0,18 & $1,27^{*}$ & 1,00 & $3,33^{*}$ & 0,47 \\
meses & & & & & & & & \\
24 & 0,45 & 0,43 & 0,92 & 0,16 & 0,73 & 0,67 & 1,67 & 0,20 \\
meses & & & & & & & & \\
\hline
\end{tabular}

- $\quad$ significante se $p<0,05$ 


\subsubsection{2 Índices complementares}

Além do incremento de cárie, outras variáveis clínicas foram estudadas (PHP; CNTP e capacidade tampão salivar) e avaliadas ao longo do estudo (Teste de Friedman) e entre os grupos (Teste de Mann-Whitney).

As diferenças observadas entre as mães dos grupos EX e CT não apresentaram significância estatística em nenhum momento do estudo. Tabela 13.

Porém, entre os grupos de mães de bebês com e sem cárie observouse diferença significativa na variável PHP 24m, indicando um maior acúmulo de placa no grupo Mães-c/a ( $p=0,003)$. Tabela 14 .

TABELA 13 - Comparação entre os índices PHP, ICNTP e capacidade tampão salivar (CTS) dos grupos EX e CT ao longo do estudo. Teste de Mann Whitney

\begin{tabular}{c|cccc}
\hline Variável & $\begin{array}{c}E X \\
\text { Mediana }\end{array}$ & $\begin{array}{c}C T \\
\text { Mediana }\end{array}$ & $Z$ & $p$ \\
\hline PHP base & 3,30 & 2,60 & 0,991 & 0,321 \\
PHP 6 m & 2,50 & 2,15 & 0,155 & 0,88 \\
PHP 24m & 3,05 & 3,20 & $-0,331$ & 0,74 \\
ICNTP base & 2,00 & 2,00 & 0,985 & 0,32 \\
ICNTP 6m & 1,00 & 1,50 & $-0,115$ & 0,91 \\
ICNTP 24m & 2,00 & 2,00 & 0,742 & 0,46 \\
CTS base & 4,00 & 4,00 & $-0,046$ & 0,96 \\
CTS 6m & 5,00 & 5,00 & $-0,219$ & 0,83 \\
CTS 24m & 6,00 & 6,00 & $-0,546$ & 0,59 \\
\hline
\end{tabular}

significante se $p<0,05$ 
TABELA 14 - Comparação entre os índices PHP, ICNTP e capacidade tampão salivar dos grupos Mães-s/c e Mães-c/a ao longo do estudo. Teste de MannWhitney

\begin{tabular}{c|cccc}
\hline Variável & $\begin{array}{c}\text { Mães-s/c } \\
\text { mediana }\end{array}$ & $\begin{array}{c}\text { Mães-c/a } \\
\text { Mediana }\end{array}$ & $Z$ & $p$ \\
\hline PHP base & 3,00 & 3,30 & $-0,722$ & 0,470 \\
PHP 6 m & 2,20 & 3,00 & $-1,190$ & 0,233 \\
PHP 24m & 3,00 & 3,70 & $-2,893$ & 0,003 * \\
ICNTP base & 2,00 & 2,00 & $-0,671$ & 0,502 \\
ICNTP 6m & 1,00 & 1,00 & 0,486 & 0,627 \\
ICNTP 24m & 2,00 & 2,00 & $-0,597$ & 0,550 \\
CTS base & 4,00 & 4,00 & 1,656 & 0,097 \\
CTS 6m & 5,00 & 5,00 & 1,298 & 0,194 \\
CTS 24m & 6,00 & 6,00 & 0,930 & 0,352 \\
\hline
\end{tabular}

significante se $p<0,05$.

Considerando o comportamento de uma mesma variável nos diferentes períodos de avaliação observou-se, através do Teste de Friedman e do Teste de comparações múltiplas de Student-Newman-Keuls, comportamento similar entre os grupos Experimental e Controle. Tabela 15.

Houve uma diminuição significativa para a variável PHP na avaliação de 6 meses quando comparada às avaliações inicial e final, para ambos os grupos (EX e CT). Com relação à variável ICNTP observou-se diferença estatística entre as 
avaliações inicial e a realizada no período de seis meses, para ambos os grupos (EX e CT).

A variável capacidade tampão salivar diferiu a cada avaliação, apresentando valores crescentes em ambos os grupos.

O fluxo salivar apresentou grandes variações intra-pacientes (Tabela 16). Para avaliar a correlação entre o fluxo salivar e o incremento de cárie, as pacientes foram dividas em pacientes com fluxo normal ou insatisfatório. O fluxo foi considerado insatisfatório quando os valores coletados foram inferiores a 0,7 $\mathrm{mL} / \mathrm{min}$. em todas as avaliações. Estas pacientes foram comparadas com outras cujo fluxo mostrou-se superior a $0,7 \mathrm{~mL} / \mathrm{min}$. em todas coletas. Procurando-se portanto simplificar a análise estatística através da comparação de grupos extremos (Tabela 17).

TABELA 15 - Avaliação comparativa dos ìndices PHP, ICNTP e CTS longitudinalmente. Teste de Friedman

\begin{tabular}{c|cccccc}
\hline & & "Baseline" & 6 meses & 24 meses & $X^{2}$ & $p$ \\
\hline PHP & EX & $3,30^{a}$ & $2,50^{b}$ & $3,05^{a}$ & 24,41 & $<0,001^{*}$ \\
& CT & $2,60^{a}$ & $2,15^{b}$ & $3,20^{a}$ & 11,64 & $0,003^{*}$ \\
\hline ICNTP & EX & $2,00^{a}$ & $1,00^{b}$ & $2,00^{a}$ & 8,46 & $0,015^{*}$ \\
& CT & $2,00^{a}$ & $1,50^{b}$ & $2,00^{a}$ & 6,00 & 0,05 \\
\hline CTS & EX & $4,00^{a}$ & $5,00^{b}$ & $6,00^{c}$ & 46,25 & $<0,001^{*}$ \\
& CT & $4,00^{a}$ & $5,00^{b}$ & $6,00^{c}$ & 44,60 & $<0,001^{*}$
\end{tabular}

- Grupos com a mesma letra não possuem diferença estatíticamente significante. $(p<0,05)$ 
TABELA 16 - Distribuição da amostra segundo o fluxo salivar colhido em cada avaliação (Baseline, 6 meses, 24 meses): normal (N) ou insatisfatório (I).

\begin{tabular}{c|ccc}
\hline Fluxo salivar & EX & $C T$ & Total \\
\hline NNN & 26 & 21 & 47 \\
III & 3 & 5 & 8 \\
INN & 1 & 1 & 2 \\
IIN & 2 & 0 & 2 \\
NNI & 1 & 0 & 1 \\
NIN & 1 & 1 & 2 \\
NII & 0 & 2 & 2 \\
\hline
\end{tabular}

TABELA 17-Comparação entre o incremento de cárie (cavidades e lesões de mancha branca - Imb) observado nas pacientes com fluxo salivar normal ou insatisfatório - Teste t

\begin{tabular}{|c|c|c|c|c|c|c|}
\hline & \multicolumn{2}{|c|}{$\begin{array}{l}\text { Fluxo normal } \\
\qquad N=47\end{array}$} & \multicolumn{2}{|c|}{$\begin{array}{l}\text { Fluxo insatisfatório } \\
\qquad N=8\end{array}$} & \multirow[t]{2}{*}{$t$} & \multirow[t]{2}{*}{$p$} \\
\hline & Média & $D p$ & Média & $d p$ & & \\
\hline Cavidade & 2,15 & 2,03 & 3,50 & 3,30 & 1,58 & 0,12 \\
\hline Imb & 2,89 & 3,25 & 4,13 & 3,64 & 0,97 & 0,33 \\
\hline TOTAL & 5,04 & 4,31 & 7,63 & 6,02 & 1,48 & 0,15 \\
\hline
\end{tabular}




\subsection{BEBÊS}

\subsubsection{Características da amostra}

O grupo Experimental foi formado por 21 bebês do sexo feminino e 13 do sexo masculino; o grupo Controle constituiu-se de 15 bebês do sexo feminino e 15 do sexo masculino.

Cinqüenta e nove bebês nasceram a termo e cinco foram prematuros.

\subsubsection{Seqüência de erupção dentária}

Os bebês foram avaliados com as idades de 6, 12 e 24 meses. $O$ exame clínico diagnosticou o número de dentes erupcionados, e a presença ou ausência de sinais clínicos da cárie dentária. Tabela 18.

TABELA 18 - Distribuição dos bebês segundo o número de dentes irrompidos

\begin{tabular}{c|ccc}
\hline & Seis meses & 12 meses & 24 meses \\
\hline Edêntulo & 32 & 00 & 00 \\
1 a 4 incisivos & 24 & 02 & 00 \\
5 a 8 incisivos & 08 & 32 & 00 \\
Primeiros molares & 00 & 30 & 30 \\
Segundos molares & 00 & 00 & 34 \\
(17 a 20 dentes) & & & \\
Total & 64 & 64 & 64 \\
\hline
\end{tabular}




\subsubsection{Avaliação da condição de saúde bucal dos bebês}

\subsubsection{Atividade de cárie}

A experiência/atividade de cárie dos bebês foi avaliada através do índice ceos, que resumiu-se no índice sc, o qual identifica o número de superfícies dentárias cariadas (cavitadas) em dentes decíduos, e através da contagem do número de superfícies com lesões de mancha branca.

$\mathrm{Na}$ avaliação de 12 meses, dois bebês do grupo CT $(6,7 \%)$ apresentaram sinais iniciais de cárie (desmineralizações) na superfície vestibular dos incisivos superiores, totalizando 9 superfícies com lesões de mancha branca .

Na avaliação de 24 meses quinze bebês apresentaram-se cárie-ativos, sendo 5 do grupo Experimental e 10 do grupo Controle e 5 do sexo feminino e 10 do sexo masculino.

Procurourse correlacionar a atividade de cárie dos bebês com diversas variáveis que poderiam ter significância no resultado observado. Comparourse a experiência de cárie entre os grupos de bebês Experimental e Controle, Teste " $\mathrm{X}^{2}$ " e Teste "t”, Tabelas 19 e 20 e Figura 10.

TABELA 19 - Prevalência de bebês cárie ativos nos grupos Experimental e Controle. Teste "Chi-Square" ou $\mathrm{X}^{2}$

\begin{tabular}{c|ccccc}
\hline & Experimental & Controle & Total & $X^{2}$ & $p$ \\
\hline Bebê sem cárie & $29(85,29 \%)$ & $20(66,67 \%)$ & 49 & & \\
Bebê cárie ativo & $5(14,75 \%)$ & $10(33,33 \%)$ & 15 & 3,082 & 0,08 \\
Total & 34 & 30 & 64 & & \\
\hline
\end{tabular}

- $\quad$ Significante se $p<0,05$ 
A prevalência de crianças cárie ativas no grupo Controle foi superior a do grupo Experimental $(33,33 \% \times 14,71 \%$, respectivamente), atingindo um nível próximo à significância estatística.

TABELA 20 - Experiência de cárie (número médio de cavidades e desmineralizações) dos bebês dos grupos Experimental e Controle. Teste $\mathrm{t}$ de Student

\begin{tabular}{|c|c|c|c|c|c|c|}
\hline & \multicolumn{2}{|c|}{$\begin{array}{c}\text { Experimental } \\
\qquad N=05\end{array}$} & \multicolumn{2}{|c|}{$\begin{array}{l}\text { Controle } \\
N=10\end{array}$} & \multirow[t]{2}{*}{$t$} & \multirow[t]{2}{*}{$p$} \\
\hline & Média & $D p$ & Média & $\mathrm{Dp}$ & & \\
\hline Cavidade & 0,60 & 1,34 & 1,10 & 1,52 & $-0,620$ & 0,55 \\
\hline Imb & 2,60 & 1,82 & 5,20 & 3,88 & $-1,403$ & 0,18 \\
\hline TOTAL & & & & & & \\
\hline Cav. + Imb & 3,20 & 1,10 & 6,30 & 5,25 & $-1,283$ & 0,22 \\
\hline
\end{tabular}

A maneira pela qual as crianças foram acometidas pela doença também foi mais severa no grupo Controle, embora não tenha sido observada diferença estatística. No grupo CT cinco bebês apresentaram mais de seis superfícies dentárias com lesões cariosas, o que não foi observado em criança alguma no grupo Experimental.

Das 65 lesões de mancha branca diagnosticadas, 50 localizavam-se em superfícies vestibulares, 6 em superfícies proximais, 6 em regiões de cicatrícula e fissura e 3 em superfícies palatinas. 
Das 14 cavidades diagnosticadas, 9 foram observadas em superfícies oclusais, 2 em superfícies palatinas, 2 em superfícies proximais e 1 em superfície vestibular.

Os dentes mais freqüentemente afetados pela cárie foram os incisivos superiores (31) seguidos dos primeiros molares (29) e caninos (11). Os incisivos inferiores sempre foram preservados. O padrão de ataque típico da cárie de mamadeira, envolvendo a superfície vestibular dos incisivos superiores foi observado em 8 bebês, sendo 5 do grupo Controle e 3 do grupo Experimental. Em dois bebês foram observadas lesões nas superfícies vestibulares de caninos e molares. Nos demais foram diagnosticadas lesões nas superfícies oclusais dos primeiros molares (3) e nas proximais dos incisivos (2). Figuras 10 e 11.

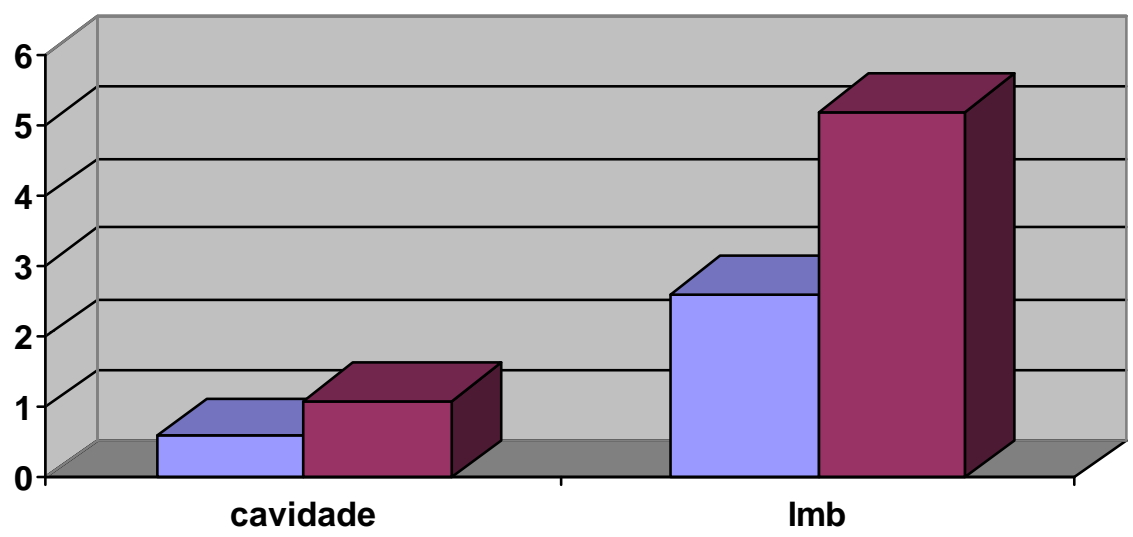

FIGURA 10 - Experiência de cárie (média de cavidades e desmineralizações) dos bebês cárie ativos dos grupos Experimental e Controle 

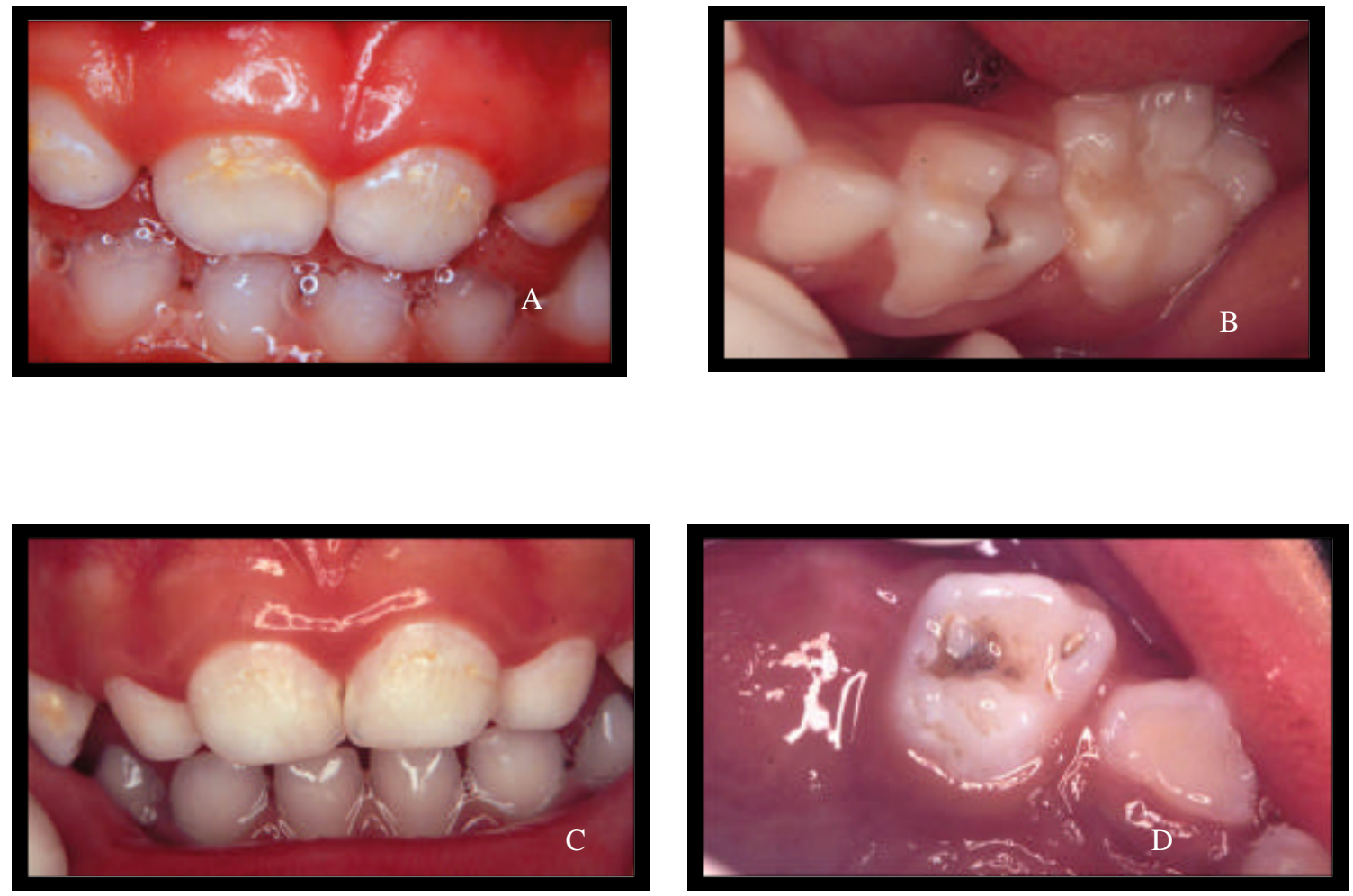

FIGURA 11 - Bebês cárie ativos: A. Paciente T. V. S., 27 meses, grupo Controle B. Paciente L. A. P. M., 28 meses, grupo Controle. C. Paciente J. H. G. C., 28 meses, grupo Controle. D. Paciente T. C. O. S., 24 meses, grupo Experimental. 
Correlacionou-se a experiência de cárie dos bebês com outras variáveis qualitativas como a presença de placa visível na superfície vestibular dos incisivos superiores, Tabelas 21 e 22; presença de gengivite, Tabela 23; higienização diária dos dentes dos bebês relatada pelas mães nas avaliações de 12 e 24 meses, Tabelas 24 e 25; e com o padrão de amamentação, Tabelas 26, 27 e 28. Algumas variáveis maternas também foram consideradas, como idade, Tabela 29; classe social, Tabela 30; e nível de escolaridade, Tabela 31.

A correlação entre a atividade de cárie dos bebês e o incremento de cárie das mães foi significativo conforme demonstrado na Tabela 11.

TABELA 21 - Correlação entre a presença de placa visível nos incisivos superiores (diagnosticada na avaliação de 12 meses) e a atividade de cárie dos bebês - Teste de Fisher

\begin{tabular}{c|cccc}
\hline & $\begin{array}{c}\text { Ausência de placa } \\
\text { visível }\end{array}$ & Presença de & Total & $p$ \\
& $27(55,1 \%)$ & $22(44,9 \%)$ & 49 & \\
\hline Bebê sem cárie & $5(33,33 \%)$ & $10(66,67 \%)$ & 15 & 0,12 \\
Bebê cárie ativo & $32(50 \%)$ & $32(50 \%)$ & 64 & \\
Total & & & & \\
\hline
\end{tabular}


TABELA 22 - Correlação entre a presença de placa visível nos incisivos superiores (24 meses) e a atividade de cárie dos bebês - Teste de Fisher

\begin{tabular}{c|cccc}
\hline & $\begin{array}{c}\text { Ausência de } \\
\text { placa visível }\end{array}$ & Presença de placa visível & Total & $p$ \\
\hline Bebê sem cárie & $25(51,02 \%)$ & $24(48,98 \%)$ & 49 & \\
Bebê cárie ativo & $2(13,33 \%)$ & $13(86,67 \%)$ & 15 & 0,008 * \\
Total & 27 & 37 & 64 & \\
\hline
\end{tabular}

- * Significante se $p<0,05$

TABELA 23 - Correlação entre a presença de gengivite e a atividade de cárie dos bebês. Teste de Fisher - 24 meses

\begin{tabular}{c|cccc}
\hline & Ausência de gengivite & Presença de gengivite & Total & $p$ \\
\hline Bebê sem cárie & $44(89,8 \%)$ & $5(10,2 \%)$ & 49 & \\
Bebê cárie ativo & $11(73,33 \%)$ & $4(26,67 \%)$ & 15 & 0,20 \\
Total & 55 & 9 & 64 & \\
\hline
\end{tabular}

TABELA 24 - Correlação entre a realização de higienização diária relatada pela mãe na avaliação de 12 meses e a atividade de cárie dos bebês. Teste $X^{2}$

\begin{tabular}{c|ccccc}
\hline & $\begin{array}{c}\text { Ausência de } \\
\text { higienização }\end{array}$ & Presença de & Total & $X^{2}$ & $p$ \\
& higienização & & & \\
\hline Bebê sem cárie & $20(40,8 \%)$ & $29(59,2 \%)$ & 49 & & \\
Bebê cárie ativo & $8(53,3 \%)$ & $7(46,7 \%)$ & 15 & 0,731 & 0,39 \\
Total & 28 & 36 & 64 & & \\
\hline
\end{tabular}


TABELA 25 - Correlação entre a realização de higienização diária relatada pela mãe na avaliação de 24 meses e a atividade de cárie dos bebês. Teste $X^{2}$

\begin{tabular}{c|ccccc}
\hline & $\begin{array}{c}\text { Ausência de } \\
\text { higienização }\end{array}$ & $\begin{array}{c}\text { Presença de } \\
\text { higienização }\end{array}$ & Total & $X^{2}$ & $P$ \\
\hline Bebê sem cárie & $15(30,6 \%)$ & $34(69,4 \%)$ & 49 & & \\
Bebê cárie ativo & $7(46,7 \%)$ & $8(53,3 \%)$ & 15 & 1,312 & 0,25 \\
Total & 22 & 42 & 64 & & \\
\hline
\end{tabular}

TABELA 26 - Correlação entre o padrão de amamentação (aleitamento materno x mamadeira) na avaliação de 12 meses e a atividade de cárie dos bebês. Teste de Fisher

\begin{tabular}{c|cccc}
\hline & Aleitamento & Mamadeira & Total & $P$ \\
& Materno & Doce & & \\
\hline Bebê sem cárie & $8(16,3 \%)$ & $41(83,7 \%)$ & 49 & \\
Bebê cárie ativo & $1(6,7 \%)$ & $14(93,3 \%)$ & 15 & 0,67 \\
Total & 9 & 55 & 64 & \\
\hline
\end{tabular}


TABELA 27 - Correlação entre o padrão de amamentação (aleitamento materno x mamadeira) na avaliação de 24 meses e a atividade de cárie dos bebês. Teste de Fisher

\begin{tabular}{c|cccc}
\hline & $\begin{array}{c}\text { Aleitamento } \\
\text { Materno }\end{array}$ & Mamadeira & Total & $p$ \\
& $3(6,1 \%)$ & $46(93,9 \%)$ & 49 & \\
\hline Bebê sem cárie & $1(6,7 \%)$ & $14(93,3 \%)$ & 15 & 0,27 \\
Bebê cárie ativo & 4 & 60 & 64 & \\
Total & & & & \\
\hline
\end{tabular}

TABELA 28 - Correlação entre a atividade de cárie dos bebês e a freqüência de mamadas noturnas com as idades de 12 e 24 meses. Teste t de Student

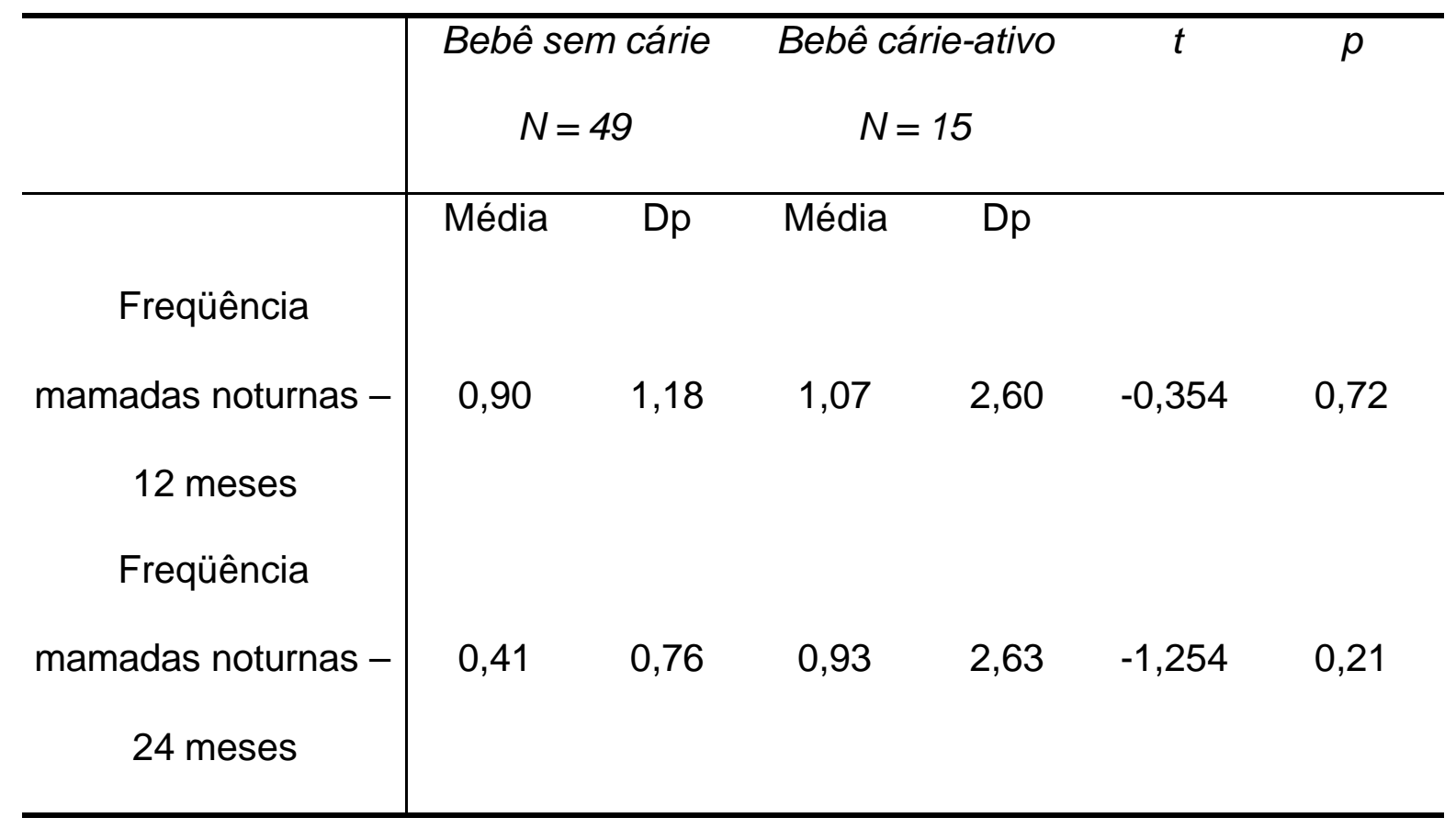


TABELA 29- Correlação entre a atividade de cárie dos bebês e a idade das mães. Teste t de Student

\begin{tabular}{|c|c|c|c|c|c|c|}
\hline & \multicolumn{2}{|c|}{$\begin{array}{l}\text { Bebê sem cárie } \\
\qquad N=49\end{array}$} & \multicolumn{2}{|c|}{$\begin{array}{l}\text { Bebê cárie-ativo } \\
\qquad N=15\end{array}$} & \multirow[t]{2}{*}{$t$} & \multirow[t]{2}{*}{$p$} \\
\hline & Média & $\mathrm{Dp}$ & Média & $\mathrm{Dp}$ & & \\
\hline Idade & 19,33 & 3,96 & 18,47 & 2,0 & 0,807 & 0,42 \\
\hline
\end{tabular}

TABELA 30 - Correlação entre a atividade de cárie dos bebês e a classe social. Teste $\mathrm{X}^{2}$

\begin{tabular}{c|ccccc}
\hline Classe social & Bebê sem cárie & Bebê cárie-ativo & Total & $X^{2}$ & $p$ \\
& $N=49$ & $N=15$ & & & \\
\hline C & $17(34,69 \%)$ & $5(33,33 \%)$ & 22 & & \\
D + E & $32(65,31 \%)$ & $10(66,67 \%)$ & 42 & 0,009 & 0,92 \\
Total & 49 & 15 & & & \\
\hline
\end{tabular}

TABELA 31 - Correlação entre a atividade de cárie dos bebês e o grau de instrução (escolaridade) das mães. Teste de Mann-Whitney

\begin{tabular}{c|cccc}
\hline Escolaridade & $\begin{array}{c}\text { Bebê sem cárie } \\
N=49\end{array}$ & $\begin{array}{c}\text { Bebê cárie-ativo } \\
N=15\end{array}$ & Total \\
\hline Escore 1 & 06 & 0 & 06 & \\
Escore 2 & 25 & 14 & 39 & \\
Escore 3 & 13 & 01 & 14 & 0,20 \\
Escore 4 & 05 & 0 & 05 & \\
Total & 49 & 15 & 64 & \\
\hline
\end{tabular}

* significante se $p<0,05$ 


\subsection{MATERIAIS RESTAURADORES}

Nas avaliações de 12 e 24 meses, realizou-se também a análise do comportamento clínico dos materiais restauradores empregados no procedimento de adequação bucal.

As restaurações foram avaliadas de acordo com os códigos expostos na Tabela 32. Os códigos 1 e 2 indicam restaurações satisfatórias, enquanto os demais códigos são indicadores de insucessos.

No grupo Experimental foram realizadas 417 restaurações de cimento de ionômero de vidro Fuji IX em 43 pacientes. Após 1 ano 383 restaurações, colocadas em 39 pacientes foram avaliadas, Tabela 33. Após 2 anos 302 restaurações foram reavaliadas em 34 pacientes, Tabela 34.

No grupo Controle foram realizadas 213 restaurações de cimento de óxido de zinco e eugenol reforçado IRM em dentes posteriores e 127 restaurações de resina composta Fill-Magic em cavidades Classes III, IV e V em 38 pacientes. Após 1 ano foram reavaliadas 183 e 111 restaurações dos respectivos materiais em 31 pacientes, Tabelas 35 e 37 . Após 2 anos foram reavaliadas 38 restaurações de IRM e 106 restaurações de resina composta em 30 pacientes, Tabelas 36 e 38.

As porcentagens de pacientes avaliados após 1 e dois anos foram 90,7\% e $79 \%$ para o grupo Experimental e $81,6 \%$ e $78,9 \%$ para o grupo Controle, respectivamente. O pequeno número de restaurações de IRM avaliadas após 2 anos deveu-se ao fato de que toda restauração classificada como insatisfatória na primeira avaliação foi excluída da segunda reavaliação. 
Os materiais foram comparados estatisticamente através do Teste $\mathrm{X}^{2}$, considerando-se a Classe da restauração, ou seja, o cimento Fuji IX foi comparado com o cimento IRM nos preparos Classe I e II, Tabelas 39 e 40 e com a resina composta Fill Magic nos preparos Classe III, IV e V, Tabelas 41 e 42.

Observou-se diferença estatística entre os cimento Fuji IX e IRM em ambos períodos de avaliação. O cimento Fuji IX e a resina Fill Magic apresentaram comportamento similar.

A longevidade das restaurações foi determinada através da estimativa da taxa cumulativa de sucesso (curva de sobrevivência) com intervalo de confiança de $95 \%$, Tabelas 43 e 44 .

No grupo Experimental o cimento ionomérico foi aplicado em todos os tipos de restaurações, tanto simples como compostas ou complexas. Realizourse a análise do desempenho deste cimento nas diferentes situações, através do Teste $X^{2}$, agrupando-se as restaurações de uma superfície (I, III e V) e de duas ou mais superfícies (II, IV e reconstruções), Tabelas 45 e 46 . Foram classificadas como reconstruções restaurações que envolviam mais do que dois terços da coroa dentária. As diferenças observadas não atingiram significância estatística, embora no primeiro ano do estudo tenham ficado bem próximo de atingi-la. 
TABELA 32 - Códigos utilizados para a avaliação clínica das restaurações

\begin{tabular}{c|cc}
\hline Código & Critério & Definição \\
\hline 1 & Presente e correta & Sucesso \\
\hline 2 & $\begin{array}{c}\text { Presente, pequeno defeito marginal e/ou desgaste de } \\
\text { superfície com menos de 0,5 mm; sem necessidade de } \\
\text { reparo }\end{array}$ & Sucesso \\
\hline 3 & Presente, defeito marginal superior a 0,5 mm. & Falha \\
& Necessidade de reparo & \\
\hline 4 & $\begin{array}{c}\text { Presente, desgaste de grande parte da restauração } \\
\text { superior a 0,5 mm. Necessidade de reparo }\end{array}$ & Falha \\
\hline 5 & Presença de cárie na margem da restauração. & Falha \\
& Necessidade de reparo & \\
\hline 6 & Parcialmente presente, fratura da restauração e/ou & Falha \\
& dente. Necessidade de reparo & Falha \\
\hline 7 & Ausente, restauração completamente perdida. & \\
\hline 8 & Necessidade de tratamento & Excluído \\
\hline 9 & Ausente, outro tratamento restaurador realizado & Excluído \\
\hline 10 & Dente ausente devido à extração & Falha \\
\hline
\end{tabular}


TABELA 33 - Taxa de sucesso das restaurações de cimento de ionômero de vidro Fuji IX após 1 ano

\begin{tabular}{|c|c|c|c|c|}
\hline \multirow[t]{2}{*}{ Classe } & \multirow{2}{*}{$\begin{array}{c}\text { Colocadas } \\
\text { (N) }\end{array}$} & \multirow{2}{*}{$\begin{array}{c}\text { Avaliadas } \\
\text { (N) }\end{array}$} & \multicolumn{2}{|c|}{ Taxa de sucesso } \\
\hline & & & $\mathrm{N}$ - Código & $\%$ \\
\hline \multirow[t]{2}{*}{$\mathrm{I}$} & 143 & 125 & $110-1$ & 99,20 \\
\hline & & & $14-2$ & \\
\hline \multirow[t]{2}{*}{ II } & 92 & 84 & $61-1$ & 91,67 \\
\hline & & & $16-2$ & \\
\hline \multirow[t]{2}{*}{ III } & 138 & 134 & $111-1$ & 94,03 \\
\hline & & & $15-2$ & \\
\hline \multirow[t]{2}{*}{$\mathrm{IN}$} & 5 & 5 & $3-1$ & 100 \\
\hline & & & $2-2$ & \\
\hline \multirow[t]{2}{*}{ V } & 24 & 21 & $16-1$ & 95,24 \\
\hline & & & $4-2$ & \\
\hline \multirow[t]{2}{*}{ Reconstrução } & 15 & 14 & $5-1$ & 85,71 \\
\hline & & & $7-2$ & \\
\hline Total & 417 & 383 & 364 & 95,04 \\
\hline
\end{tabular}


TABELA 34 - Taxa de sucesso das restaurações de cimento de ionômero de vidro Fuji IX após 2 anos

\begin{tabular}{|c|c|c|c|c|}
\hline \multirow[t]{2}{*}{ Classe } & \multirow{2}{*}{$\begin{array}{l}\text { Colocadas } \\
\text { (N) }\end{array}$} & \multirow{2}{*}{$\begin{array}{c}\text { Avaliadas } \\
\text { (N) }\end{array}$} & \multicolumn{2}{|c|}{ Taxa de sucesso } \\
\hline & & & N-Código & $\begin{array}{c}\% \\
\text { (cumulativa) }\end{array}$ \\
\hline $\mathrm{I}$ & 143 & 103 & $\begin{array}{l}72-1 \\
24-2\end{array}$ & 92,45 \\
\hline II & 92 & 67 & $\begin{array}{l}52-1 \\
12-2\end{array}$ & 87,56 \\
\hline III & 138 & 103 & $\begin{array}{l}81-1 \\
20-2\end{array}$ & 92,21 \\
\hline $\mathrm{IV}$ & 5 & 5 & $\begin{array}{l}3-1 \\
2-2\end{array}$ & 100 \\
\hline V & 24 & 14 & $\begin{array}{l}10-1 \\
3-2\end{array}$ & 88,44 \\
\hline Reconstrução & 15 & 10 & $\begin{array}{l}4-1 \\
5-2\end{array}$ & 77,14 \\
\hline Total & 417 & 302 & 288 & 90,63 \\
\hline
\end{tabular}


TABELA 35 - Taxa de sucesso das restaurações de cimento de óxido de zinco e eugenol - IRM após 1 ano

\begin{tabular}{|c|c|c|c|c|}
\hline \multirow[t]{2}{*}{ Classe } & \multirow{2}{*}{$\begin{array}{c}\text { Colocadas } \\
\text { (N) }\end{array}$} & \multirow{2}{*}{$\begin{array}{l}\text { Avaliadas } \\
\text { (N) }\end{array}$} & \multicolumn{2}{|c|}{ Taxa de sucesso } \\
\hline & & & $\mathrm{N}$ - Código & $\%$ \\
\hline \multirow[t]{2}{*}{$\mathrm{I}$} & 134 & 114 & $1-1$ & 26,32 \\
\hline & \multicolumn{4}{|c|}{$29-2$} \\
\hline \multirow[t]{2}{*}{ II } & \multirow[t]{2}{*}{75} & \multirow[t]{2}{*}{67} & $1-1$ & \multirow[t]{2}{*}{14,93} \\
\hline & & & $9-2$ & \\
\hline Reconstrução & 4 & 2 & 0 & 0 \\
\hline Total & 213 & 183 & 40 & 21,86 \\
\hline
\end{tabular}

TABELA 36 - Taxa de sucesso das restaurações de cimento de óxido de zinco e eugenol - IRM após 2 anos

\begin{tabular}{|c|c|c|c|c|}
\hline \multirow[t]{2}{*}{ Classe } & \multirow{2}{*}{$\begin{array}{c}\text { Colocadas } \\
\text { (N) }\end{array}$} & \multirow{2}{*}{$\begin{array}{c}\text { Avaliadas } \\
\text { (N) }\end{array}$} & \multicolumn{2}{|c|}{ Taxa de sucesso } \\
\hline & & & N-Código & $\begin{array}{c}\% \\
\text { (cumulativa) }\end{array}$ \\
\hline 1 & 134 & 29 & $14-2$ & 12,71 \\
\hline II & 75 & 9 & $\begin{array}{l}1-1 \\
1-2\end{array}$ & 3,32 \\
\hline Reconstrução & 4 & 0 & 0 & 0 \\
\hline Total & 213 & 38 & 16 & 9,21 \\
\hline
\end{tabular}


TABELA 37 - Taxa de sucesso das restaurações de resina composta Fill Magic após 1 ano

\begin{tabular}{|c|c|c|c|c|}
\hline \multirow[t]{2}{*}{ Classe } & \multirow{2}{*}{$\begin{array}{c}\text { Colocadas } \\
\text { (N) }\end{array}$} & \multirow{2}{*}{$\begin{array}{c}\text { Avaliadas } \\
\text { (N) }\end{array}$} & \multicolumn{2}{|c|}{ Taxa de sucesso } \\
\hline & & & N-Código & $\%$ \\
\hline III & 104 & 90 & $\begin{array}{r}80-1 \\
8-2\end{array}$ & 97,78 \\
\hline $\mathrm{N}$ & 3 & 3 & $3-1$ & 100 \\
\hline $\mathrm{V}$ & 14 & 12 & $\begin{array}{r}11-1 \\
1-2\end{array}$ & 100 \\
\hline Reconstrução & 6 & 6 & $6-1$ & 100 \\
\hline Total & 127 & 111 & 109 & 98,20 \\
\hline
\end{tabular}

TABELA 38 - Taxa de sucesso das restaurações de resina composta Fill Magic após 2 anos

\begin{tabular}{|c|c|c|c|c|}
\hline \multirow[t]{2}{*}{ Classe } & \multirow{2}{*}{$\begin{array}{l}\text { Colocadas } \\
\text { (N) }\end{array}$} & \multirow{2}{*}{$\begin{array}{l}\text { Avaliadas } \\
(N)\end{array}$} & \multicolumn{2}{|c|}{ Taxa de sucesso } \\
\hline & & & N-Código & $\begin{array}{c}\% \\
\text { (cumulativa) }\end{array}$ \\
\hline III & 104 & 87 & $\begin{array}{r}78-1 \\
4-2\end{array}$ & 92,16 \\
\hline $\mathrm{N}$ & 3 & 2 & $2-1$ & 100 \\
\hline $\mathrm{V}$ & 14 & 11 & $\begin{array}{r}10-1 \\
1-2\end{array}$ & 100 \\
\hline Reconstrução & 6 & 6 & $6-1$ & 100 \\
\hline Total & 127 & 106 & 101 & 93,56 \\
\hline
\end{tabular}


TABELA 39 - Comparação entre o desempenho clínico dos cimentos Fuji IX e IRM em cavidades Classe I e II. Teste $\mathrm{X}^{2}$. Avaliação de 1 ano

\begin{tabular}{c|ccccc}
\hline Material & Sucesso & Insucesso & Total & $X^{2}$ & $p$ \\
\hline Fuji IX & 201 & 8 & 209 & & \\
IRM & 40 & 141 & 181 & 222,3 & $<0,0001$ * \\
\hline
\end{tabular}

- * Significante se $p<0,05$

TABELA 40 - Comparação entre o desempenho clínico dos cimentos Fuji IX e IRM em cavidades Classe I e II. Teste $X^{2}$. Avaliação de 2 anos

\begin{tabular}{c|ccccc}
\hline Material & Sucesso & Insucesso & Total & $X^{2}$ & $p$ \\
\hline Fuji IX & 160 & 10 & 170 & 60,61 & $<0,0001^{*}$ \\
IRM & 16 & 22 & 38 & & \\
& & & & & \\
\hline
\end{tabular}

- * Significante se $p<0,05$

TABELA 41 - Comparação entre o desempenho clínico do cimento Fuji IX e da resina Fil Magic em cavidades Classe III, IV, e V. Teste $X^{2}$. Avaliação de 1 ano

\begin{tabular}{c|ccccc}
\hline Material & Sucesso & Insucesso & Total & $X^{2}$ & $p$ \\
\hline Fuji IX & 151 & 9 & 160 & 1,37 & 0,24 \\
Fill Magic & 103 & 2 & 105 & & \\
\hline
\end{tabular}

- $\quad$ Significante se $p<0,05$ 
TABELA 42 - Comparação entre o desempenho clínico do cimento Fuji IX e da resina Fil Magic em cavidades Classe III, IV, e V. Teste $X^{2}$. Avaliação de 2 anos

\begin{tabular}{c|ccccc}
\hline Material & Sucesso & Insucesso & Total & $X^{2}$ & $p$ \\
\hline Fuji IX & 119 & 3 & 122 & 0,42 & 0,52 \\
Fill Magic & 95 & 5 & 100 & & \\
\hline
\end{tabular}

TABELA 43 - Longevidade das restaurações determinada através da estimativa da taxa cumulativa de sucesso, com intervalo de confiança de $95 \%$

\begin{tabular}{|c|c|c|c|c|c|}
\hline & \multicolumn{4}{|c|}{ Avaliações } & \multirow[b]{2}{*}{$\mathrm{X}^{2}$} \\
\hline & $\begin{array}{c}\text { "Baseline } \\
\text { (n) }\end{array}$ & $1 \mathrm{Ano}$ & $\mathrm{X}^{2}$ & 2 Anos & \\
\hline $\begin{array}{c}\text { Fuji IX } \\
\text { (Classes I ; II) }\end{array}$ & 235 & $\begin{array}{c}96,17 \\
(93,57-98,77)\end{array}$ & + & $\begin{array}{c}90,51 \\
(86,32-94,71)\end{array}$ & + \\
\hline $\begin{array}{c}\text { IRM } \\
\text { (Classes I ; II) }\end{array}$ & 209 & $\begin{array}{c}22,10 \\
(16,05-28,14)\end{array}$ & $\begin{array}{c}\text { Significante } \\
\mathrm{P}<0,0001\end{array}$ & $\begin{array}{c}9,31 \\
(5,0-13,61)\end{array}$ & $\begin{array}{c}\text { Significante } \\
\mathrm{P}<0,0001\end{array}$ \\
\hline $\begin{array}{c}\text { Fuji IX } \\
\text { (Classes III, IV and V) }\end{array}$ & 167 & $\begin{array}{c}94,38 \\
(90,8-97,95)\end{array}$ & $\begin{array}{c}\text { Não } \\
\text { Significante }\end{array}$ & $\begin{array}{c}92,06 \\
(87,71-96,4)\end{array}$ & $\begin{array}{c}\text { Não } \\
\text { significante }\end{array}$ \\
\hline $\begin{array}{c}\text { Resina Composta } \\
\text { (Classes III, IV and V) }\end{array}$ & 121 & $\begin{array}{c}98,1 \\
(95,48-100)\end{array}$ & $\mathrm{P}=0,24$ & $\begin{array}{c}93,19 \\
(88,32-98,06)\end{array}$ & $\mathrm{P}=0,52$ \\
\hline
\end{tabular}

\footnotetext{
${ }^{\star}$ Statisticamente significante se $\mathrm{p}<0,05$
} 
TABELA 44 - Longevidade das restaurações determinada através da estimativa da taxa cumulativa de sucesso, com intervalo de confiança de $95 \%$

\begin{tabular}{|c|c|c|c|c|c|}
\hline & \multicolumn{4}{|c|}{ Avaliações } & \multirow[b]{2}{*}{$\mathrm{X}^{2}$} \\
\hline & $\begin{array}{c}\text { "Baseline } \\
\text { (n) }\end{array}$ & 1 Ano & $\mathrm{X}^{2}$ & 2 Anos & \\
\hline Fuji IX & 305 & 96,43 & & 92,04 & \\
\hline $\begin{array}{c}\text { Uma superfície } \\
\text { (classes I, III and V) }\end{array}$ & & $(94,25-98,6)$ & $\begin{array}{c}\text { Não } \\
\text { Significante }\end{array}$ & $(88,68-95,41)$ & $\begin{array}{c}\text { Não } \\
\text { significante }\end{array}$ \\
\hline & & & $\mathrm{P}=0,07$ & & $\mathrm{P}=0,85$ \\
\hline Fuji IX & 112 & 91,26 & & 86,81 & \\
\hline $\begin{array}{l}\text { Duas ou mais } \\
\text { superfícies } \\
\text { (classes II, IV and } \\
\text { reconstruções) }\end{array}$ & & $(85,81-96,72)$ & & $(80,1-93,52)$ & \\
\hline
\end{tabular}

${ }^{*}$ Statisticamente significante se $\mathrm{p}<0,05$

TABELA 45 - Comparação entre o desempenho clínico do cimento Fuji IX em cavidades de uma (I, III, V) ou mais superfícies (II, IV, reconstruções). Teste $X^{2}$. Avaliação de 1 ano

\begin{tabular}{c|ccccc}
\hline Fuji IX & Sucesso & Insucesso & Total & $X^{2}$ & $p$ \\
\hline (I, III, V) & 270 & 10 & 280 & 3,24 & 0,072 \\
(II, IV, reconstruções) & 94 & 9 & 103 & & \\
\hline
\end{tabular}

- * Significante se $p<0,05$ 
TABELA 46 - Comparação entre o desempenho clínico do cimento Fuji IX em cavidades de uma (I, III, V) ou mais superfícies (II, IV, reconstruções). Teste X2. Avaliação de 2 anos

\begin{tabular}{c|ccccc}
\hline Fuji IXI & Sucesso & Insucesso & Total & $X^{2}$ & $p$ \\
\hline (I, III, V) & 210 & 10 & 220 & 0,03 & 0,85 \\
(II, IV, reconstruções) & 78 & 4 & 82 & & \\
\hline
\end{tabular}

- * Significante se $p<0,05$

TABELA 47- Tipo de falhas observadas entre os materiais restauradores

\begin{tabular}{c|ccc}
\hline Tipo de falha & Fuji IX & IRM & Fill Magic \\
\hline 3 & 10 & 19 & 04 \\
4 & 01 & 36 & - \\
5 & 04 & - & 01 \\
6 & 04 & 42 & - \\
7 & 09 & 60 & - \\
10 & 04 & - & 02 \\
Total & 32 & 157 & 07 \\
\hline
\end{tabular}


Para o cimento Fuji IX observourse que as falhas relacionaram-se a defeitos marginais $(3,01 \%)$, desgaste excessivo $(0,33 \%)$, fratura da restauração e/ou dente $(1,18 \%)$, perda da restauração $(2,42 \%)$ e recidiva de cárie $(1,18 \%)$. Sensibilidade pós operatória persistente foi observada em 4 restaurações $(1,11 \%)$. Nenhuma restauração foi substituída por outro tratamento restaurador.

Para a resina composta quatro restaurações apresentaram defeito marginal $(3,77 \%)$, estando uma delas associada à recidiva de cárie. Sensibilidade pós operatória prolongada foi observada em duas restaurações Classe III, de uma mesma paciente.

Para o cimento de óxido de zinco e eugenol, a perda da restauração foi a falha mais freqüentemente observada $(39,26 \%)$, seguida da fratura da restauração e/ou dente $(32,36 \%)$, mais comum em restaurações Classe II e do desgaste excessivo generalizado (24,51\%), mais comum em cavidades Classe I. Muitos dentes apresentaram recidiva de cárie (código 5) e sensibilidade ou envolvimento pulpar (código 10), porém, estes problemas estavam associados a outras falhas e não puderam ser computados. Três pacientes procuraram outro profissional para substituição das restaurações insatisfatórias.

As Figuras 12 a 16 exemplificam o comportamento clínico dos materiais restauradores. 

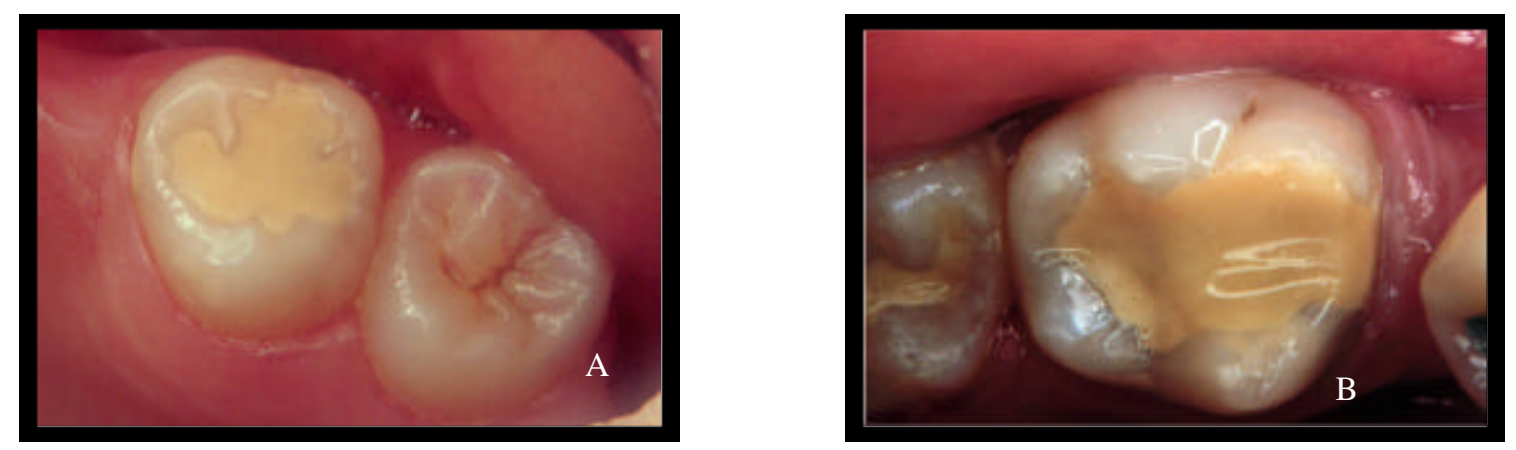

FIGURA 12 - Comportamento clínico satisfatório (código 1) do cimento Fuji IX em preparos Classe I (A) e Classe II (B).
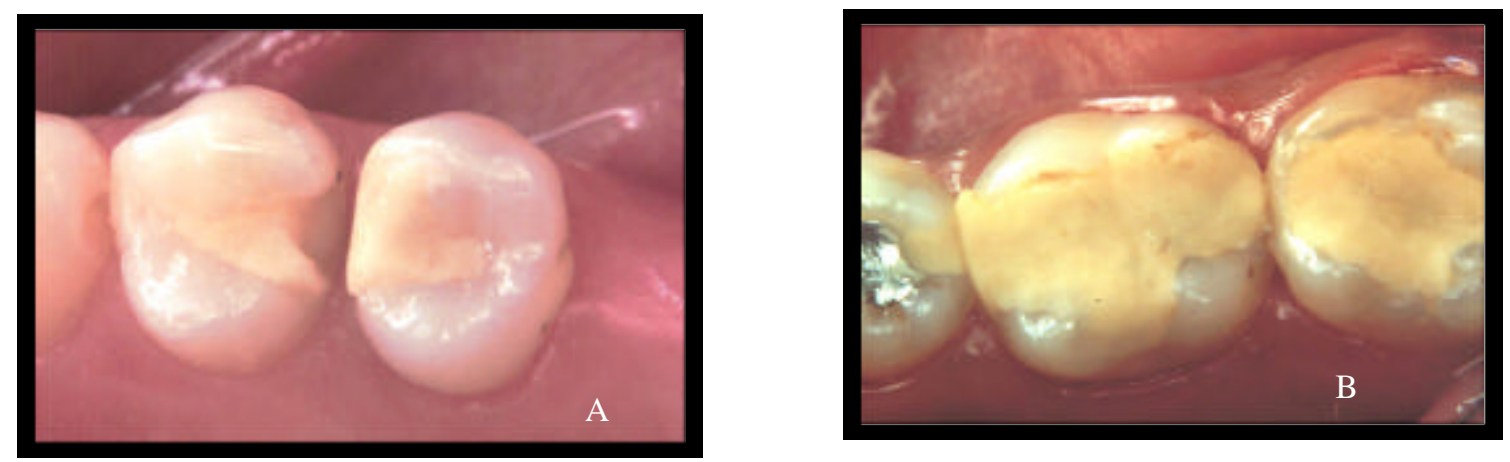

FIGURA 13 - Falhas clínicas observadas em restaurações feitas com cimento de ionômero de vidro. A. Fratura da restauração (código 6). B. Defeito marginal (código 3). 

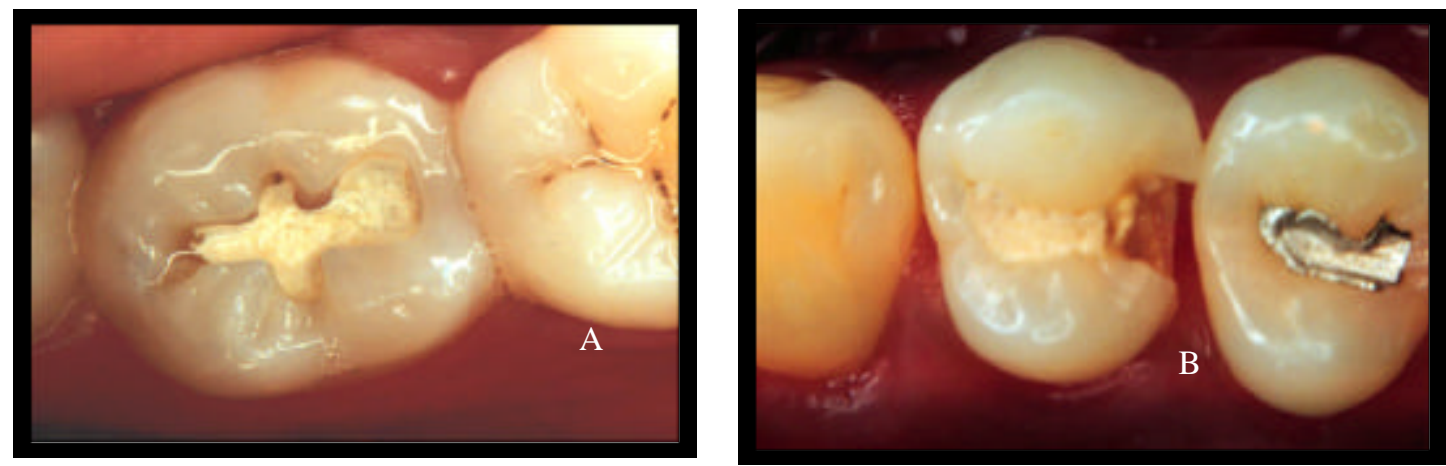

FIGURA 14 - Falhas mais freqüentemente observadas para o cimento IRM.
A. Restauração Classe I - desgaste (código 4).
B. Restauração Classe II - fratura da restauração (código 6).
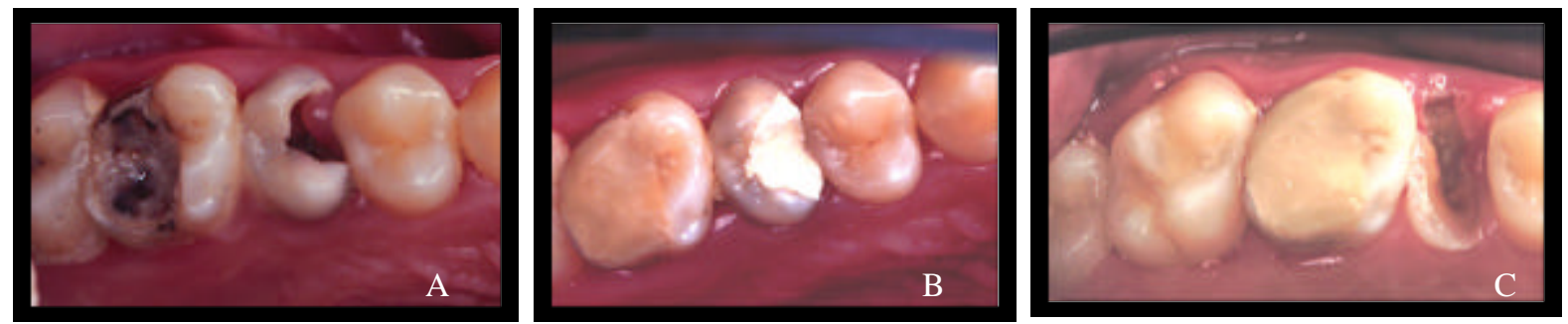

FIGURA 15 - Caso clínico.

A. Caso inicial.

B. Aspecto das restaurações

imediatamente após a adequação bucal, dente 16 - cimento Fuji IX, dente 15 cimento IRM (indicação endodôntica). C. Aspecto clínico após 15 meses.

FIGURA 16 - Insucesso ae uma restauraçao ae resına (24 meses), defeito marginal associado à recidiva de cárie (código 5) 
6 - Di scu ssã o 


\section{6 - DISCUSSÃO}

As pacientes selecionadas para o estudo receberam atenção odontológica preventiva e curativa seguindo-se as recomendações da literatura pertinente que assegura a intervenção odontológica sem intercorrências durante o período gestacional desde que a anamnese bem feita exclua outros problemas associados $^{6,34,37,69,70,71,78,80,100,105,115,119}$, e o tratamento esteja em acordo com as normas de biossegurança preconizadas pelo Ministério da Saúde 21 .

As Tabelas 1, 2, 3, e 4, mostram que o grupo estudado constituiurse de mulheres jovens, na sua maioria adolescentes, pertencentes a classes sociais menos favorecidas e com pouca escolaridade. Quase a totalidade das pacientes (57) não tinham atividade remunerada e depararam-se com a gravidez de forma não planejada. A gravidez na adolescência é fato corriqueiro nas classes sociais menos favorecidas. Não foi nosso intuito trabalhar especificamente com esta faixa etária, porém, o pré-requisito " primigesta” nos arremeteu a uma população muito jovem (75\% das pacientes entre 14 e 20 anos) que se torna mãe logo no início de sua vida sexual. Vinte pacientes experimentaram uma nova gestação durante o estudo e duas pacientes iniciavam na última avaliação sua terceira gravidez.

O perfil relatado aqui é verificado em outros estudos como o de NASCIMENTO, LOPES ${ }^{84}$ que enfatizam a somatória de variáveis que predispõem a adolescente grávida a doenças como a cárie e a gengivite: dentes permanentes recém - irrompidos, alterações hormonais decorrentes da puberdade e da gestação, hiperacidez bucal, prejuízo da higiene bucal devido a náuseas e vômitos e também 
devido a problemas emocionais, e pelo fato da preocupação estar voltada para o nascimento e cuidados da criança no pós - parto.

Adicionalmente ao exposto por NASCIMENTO, LOPES ${ }^{84}$ podemos considerar as observações de COZZUPOL ${ }^{\beta 0}$ que constatou que a necessidade odontológica da gestante é encarada como um problema menor dentro da equipe pré - natal, havendo nas classes menos favorecidas resistência da própria gestante em procurar atendimento e do dentista em atendê-la, o que não nos parece correto, pois a sanidade pré-natal deve funcionar como um todo.

As gestantes estão, portanto, carentes de assistência odontológica tanto curativa como preventiva o que pode ser comprovado através das evidentes necessidades de tratamento enfocadas pela literatura em populações obstétricas de diversos países, além da constatação da falta de conhecimento adequado sobre a saúde bucal delas próprias e de seus filhos $^{10,25,30,36,40,45,48,79,84,89,90,92,93,96,97,99,101,112,124}$.

Este fato é correlato com a situação sócio - econômica, sendo mais preocupante em populações de baixa renda e pouco grau de instrução ${ }^{26}$. Este grupo tem seu acesso ao cirurgião dentista limitado por barreiras financeiras e culturais e freqüentemente apresenta um perfil resistente à mudança de comportamento/ atitude ${ }^{92}$.

Neste estudo 53\% das pacientes haviam recebido orientações preventivas em outras oportunidades, porém, estas não foram seguidas. As fontes de informação referidas foram o dentista e a escola. Nenhuma gestante relatou a mãe, o que difere dos achados de CHAPMAN et $\mathrm{al}^{25}$ que entrevistando um grupo de 
303 gestantes constataram ser a mãe a principal fonte de informação sobre saúde bucal.

Esta omissão de atendimento à gestante pode ser considerada uma grande perda em saúde pública, pois negligencia-se um grupo comprovadamente receptivo a novos conhecimentos e com grande potencial de agente multiplicador de saúde ${ }^{18,25,28,36,48,79,93,97,112}$. A participação integral do cirurgião-dentista na equipe pré - natal é sugerida em diversos trabalhos ${ }^{25,30,48}$ e recomendada pelo Ministério da Saúde de nosso país ${ }^{22}$, porém COZZUPOL ${ }^{\beta 0}$ observou que $12 \%$ das gestantes entrevistadas por ela haviam procurado atendimento odontológico e haviam sido recusadas pelo profissional, percentual semelhante ao constatado em nosso estudo ( $8 \%$ ) e ao constatado no estudo de $\mathrm{MENINO}^{79}$ (15\%). Tanto no presente estudo como nos de COZZUPOL ${ }^{30}$ e $\mathrm{ROCHA}^{92}$ o motivo da procura por atendimento esteve associado aos casos de emergência em mais de 50\% dos casos, observando-se também preferência das pacientes pelo tratamento mutilador (exodontia) ao restaurador.

JAGO et $a^{48}$ enfatizam que a atuação sobre mudanças de comportamento com relação á saúde seja mais importante durante a gestação do que em qualquer outra fase da vida da mulher. Porém, esta abordagem preventiva deve ser a primeira de uma série de intervenções durante a infância de seu filho (0 a 3 anos) pois, a assimilação de conhecimentos nem sempre é acompanhado de mudança de atitude e a instituição de novos hábitos em adultos não ocorre facilmente ${ }^{36,99}$, havendo necessidade de reforço constante, ou seja, a educação é um processo e não acontece de uma hora para outra ${ }^{28}$. 
A higienização bucal adequada exige tempo e esforço e o paciente precisa estar motivado ${ }^{19,29}$. Segundo BOTTINO;MOREIRA;ROSSETINI ${ }^{19}$ e COUTO;COUTO;DUARTE ${ }^{29}$ a forma mais eficaz de motivação do paciente adulto é a atuação direta e individual paciente / profissional. Incluindo-se aqui o espelho de mão e a boca do paciente como os instrumentos mais úteis de que o profissional pode lançar mão para educação e motivação do paciente. Recursos adicionais como fotos, radiografias, "pôsters", livros, peças anatômicas, macromodelos, modelos do próprio paciente, manequins ( orientação direta), filmes, diapositivos e material impresso (orientação indireta) possivelmente tenham um efeito positivo na motivação, embora, via de regra, os conhecimentos passados não sejam capazes de modificar hábitos.

BOTTINO;MOREIRA;ROSSETINI ${ }^{19}$ observaram que a redução de placa através de um programa de motivação para pacientes adultos foi alcançada em $70 \%$ dos casos, embora o resultado ideal (ausência de placa) tenha sido atingido apenas por $7 \%$ dos pacientes. Fixaram em 5 o número de sessões de instrução de higiene necessárias para a instalação do novo hábito. Em nosso estudo realizamos a abordagem inicial e reforços aos 6 e 12 e 24 meses.

No início de nosso estudo, apenas $23 \%$ das pacientes relataram fazer uso do fio dental, hábito que aumentou consideravelmente ao final do estudo, onde $59 \%$ das pacientes relataram o uso diário do fio. A freqüência de escovação diária não se alterou de forma significativa, embora tenha sido observada uma melhora qualitativa da higiene bucal através da redução significativa dos índices ICNTP e PHP em ambos os grupos na avaliação de 6 meses (Tabela 15). Estes índices recuperaram seus valores iniciais na última avaliação ( 24 meses), estando de 
acordo com o exposto por outros autores ${ }^{19,29,99}$ que relatam a dificuldade da incorporação e manutenção de novos hábitos de saúde bucal a longo prazo.

O índice ICNTP é um método objetivo para o diagnóstico da doença periodontal e estimativa da necessidade de tratamento. No início do estudo 95,4\% das gestantes necessitavam de algum tratamento periodontal. Atividades exclusivamente preventivas atenderam as necessidades de tratamento de $21,9 \%$ das pacientes; enquanto 64,1\% necessitavam também de raspagem e/ou eliminação de margens restauradoras defeituosas e $9,4 \%$ de tratamento mais complexo.

Estes dados podem ser comparados aos encontrados por ROSSEL; MONTANDON-POMPEU; VALSECKI $\mathrm{JR}^{93}$ que avaliaram as necessidades periodontais de 41 gestantes através do índice RPS que é uma derivação do ICNTP. Os autores observaram que $100 \%$ das gestantes necessitavam de algum tipo de tratamento periodontal, sendo que atividades preventivas supririam as necessidades de $9,8 \%$ do grupo; $61 \%$ requeriam também raspagem e $29,2 \%$ tratamento mais complexo. No estudo de ROSSEL; MONTANDON-POMPEU; VALSECKI JR ${ }^{9}$ houve maior concentração de gestantes entre as idades de 20 e 29 anos (63\%) e em nosso trabalho $75 \%$ das pacientes tinham entre 14 e 20 anos, provavelmente devido a isto a necessidade de tratamento complexo (cirúrgico) foi menor neste, pois em ambas pesquisas constatourse um aumento da prevalência dos códigos 3 e 4 ( bolsas maior $4 \mathrm{~mm})$ com a idade.

SCAVUZZP ${ }^{97}$ também encontrou resultados comparáveis aos acima citados, identificando alteração periodontal em 95\% das gestantes por ela estudadas sendo que $73,5 \%$ das pacientes necessitavam de remoção de cálculo. 
A presença de cálculo como pior condição foi a situação de maior prevalência nos três estudos e reflexo da negligência com relação a higiene bucal em uma população jovem, o que, ao longo do tempo, leva a perda das estruturas de sustentação do dente em pessoas susceptíveis.

A placa dental, fator etiológico primário da cárie, macroscopicamente pode ser visualizada como um acúmulo esbranquiçado de espessura variável $\left.\right|^{98,109,111}$.

A ausência total de placa é raramente verificada clinicamente após 0 uso de substâncias reveladoras e é provável que haja um nível de placa compatível com a saúde clínica dos tecidos bucais ${ }^{116}$.

A velocidade de formação da placa depende de fatores locais como a rugosidade superficial, porém, é também uma conseqüência da ausência de higiene e do conteúdo, da consistência e da freqüência de ingestão da dieta.

A avaliação da higiene bucal geralmente é feita através de métodos quantitativos da placa (área coberta do dente ou espessura do substrato) que se traduzem em valores numéricos (escores). Diversos são os índices propostos para este fim variando com relação a sensibilidade e praticidade. Os métodos convencionais para registro de placa foram originalmente desenvolvido para 0 estudo das doenças periodontais ${ }^{11}$ e têm valor limitado para avaliar o risco de cárie.

Optamos pelo índice de PODSHADLEY; HALEY ${ }^{01}$ por utilizar dentes índices, ser de fácil execução e pelo fato de requerer solução evidenciadora que permite a identificação de placa mais rápida e precisa e também porque a demarcação de placa pôde ser aproveitada para educar as pacientes e assegurar a correta higiene pela escovação supervisionada. 
Para avaliação da placa dentária nos bebês foi utilizado o método preconizado por ALULUSUA; MALMIVIRTA ${ }^{8}$ que consiste na inspeção visual, sem utilização de substância evidenciadora, das superfícies vestibulares dos incisivos superiores. Classificando a placa como presente ou ausente. Neste método detecta-se o acúmulo da placa bacteriana e não sua instalação em estágio precoce como permitido com o uso de evidenciadores.

Neste estudo preconizourse a desorganização da placa através de meios mecânicos. Para as mães escovação com escova macia e pasta fluoretada e uso do fio dental, e para as crianças limpeza com gaze ou fralda umedecida em água (bebês apenas com dentes anteriores), e uso de escova infantil com uma quantidade mínima de pasta para os bebês com dentes posteriores. A técnica de limpeza instruída para os bebês mostrou-se em concordância com o estudo de VIEIRA $^{116}$

Embora vários estudos tenham investigado a relação entre higiene bucal e cárie dentária os achados ainda são inconclusivos ${ }^{11,94,109}$. Segundo THYLSTUP; FEJERSKOV ${ }^{109}$ a freqüência de escovação informada pelos pacientes tem pouca ou nenhuma relação com a prevalência de cárie, o que está de acordo com nosso estudo, Tabela 5.

Considerando-se o efeito da escovação em termos de limpeza dentária e não em termos de freqüência de escovação temos uma compreensão mais precisa. Observa-se através de estudos longitudinais correlacão entre a qualidade da limpeza, repetidamente registrada, e o incremento de cárie durante o mesmo período. Nestes estudos há correlação particular quando se examina os extremos da qualidade de limpeza bucal. Segundo SALONEN et $a^{94}$ na ausência de Sm há 
pouca correlação entre higiene bucal e incidência de lesões. Porém, na presença de Sm a maior incidência de lesões é encontrada em indivíduos com pior higiene.

Conclusões semelhantes são observadas para o uso do fio dental, ou seja, quando correta e regularmente utilizado reduz a cárie proximal e a gengivite. Porém alguns estudos avaliando o uso convencional do fio não identificaram correlação.

Apesar de haver observações na literatura relatando que a placa dentária pode ou não ser cariogênica, consideramos que sua remoção habitual é plenamente justificável, pois na ausência de placa não há lesão, uma vez que a supressão mecânica da atividade bacteriana através do distúrbio físico regular anula todos os outros fatores.

Tendo em mente a íntima associação entre a placa microbiana e a desmineralização do esmalte, a qualidade da limpeza nos locais susceptíveis á cárie parece essencial.

Em nosso estudo 3 observações interessantes devem ser discutidas com relação a este tópico: primeiramente, observou-se um acúmulo de placa estatisticamente superior no grupo de mães de bebês cárie-ativos quando comparado ao grupo de mães de bebês sem cárie (Tabela 14). Segundo, o grupo de mães de crianças cárie-ativas também apresentou um incremento de lesões de cárie, principalmente em superfície lisa, estatisticamente superior ao grupo de mães de bebês sem cárie (Tabelas 11 e 12 e Figura 9). A terceira observação, relativa aos bebês, evidencia a presença de placa nas superfícies vestibulares dos incisivos superiores com freqüência significativamente maior no grupo de bebês cárie-ativos, (Tabelas 21 e 22), o que está de acordo com os estudos de ALALUUSUA; 
MALMIVIRTA $^{8}$ e MATTOS GRANER ${ }^{75}$ que mostraram uma forte associação entre esta variável e a experiência atual e futura de cárie das crianças.

Poderíamos aqui justificar as hipóteses 1 e 3 por nós propostas, pois verificamos que a manutenção de um comportamento de risco que negligencie a higiene bucal de mãe e filho (verificados pelo superior PHP das mães e pelo acúmulo de placa nos incisivos dos bebês) esteve associado a uma superior incidência de lesões nas mães (incremento) e à manifestação da doença no bebê. Havendo ainda correlação positiva entre a atividade cariosa dos pares mãe-filho.

No entanto, aceitando-se a cárie dentária como doença de causa multifatorial devemos entender que os fatores etiológicos se combinam de maneira complexa e o nível de risco de um fator depende da influência de outros fatores.

Conceitualmente o risco sempre se refere ao futuro, podendo ser definido como a probabilidade de um indivíduo vir a desenvolver um certo número de novas lesões durante um período específico ${ }^{76}$. Porém, um mesmo nível de exposição aos fatores de risco acarreta grande variação na experiência futura de cárie entre os indivíduos. Em estudos desta natureza, busca-se a identificação de parâmetros que se mostrem fortemente associados com a atividade da doença e que, eventualmente, possam ter um bom valor de predição da experiência futura de cárie.

Neste trabalho correlação significativa foi observada entre o acúmulo de placa e a experiência de cárie tanto na população adulta como nos bebês, porém, muitas variáveis atuaram em conjunto e, embora quando analisadas isoladamente não tenham sido associadas de forma significativa com a manifestação da doença, a 
contribuição destas não pode ser descartada, mesmo que sua significância clínica não tenha podido ser estabelecida através deste estudo.

Deve-se considerar ainda que a atividade da doença foi pré-requisito para a seleção da amostra. A atividade de cárie pode ser medida no presente, diretamente, através da manifestação clínica da doença que é a prova evidente do desequilíbrio bioquímico do meio bucal. Adicionalmente observourse uma grande necessidade de tratamento acumulada (periodontal, endodôntica, exodôntica e restauradora) e uma exposição freqüente a fatores de reconhecido risco também pôde ser identificada através do exame clínico (presença de placa constante), da análise dos parâmetros salivares (fluxo e capacidade tampão), e do padrão de dieta. Além dos fatores biológicos, as características sócio-demográficas da amostra (baixo nível sócio-econômico e pouca escolaridade) ratificam a situação de alto risco ${ }^{26}$.

$\mathrm{Na}$ literatura são encontradas associações significativas entre a experiência futura de cárie e a experiência anterior de cárie, a contagem de bactérias cariogênicas (Sm e Lb) e parâmetros salivares. Dentre os previsores, a experiência de cárie parece ser o mais confiável ${ }^{76,109}$, principalmente em crianças. No entanto, não pode ser utilizado como preditor para a cárie precoce da infância, pois a dentição irrompe hígida. Torna-se então a mãe a grande fonte de informação a ser explorada com relação ao risco de cárie do bebê.

A contagem de Sm na saliva materna é fato repetitivo como preditor de risco dos bebês em todos os estudos referenciados que abordaram o efeito de medidas preventivas direcionadas à mãe na experiência de cárie de seus filhos $^{1,2,3,4,8,20,24,32,44,58,59,60,61,62,104,108}$. Nosso trabalho desponta com o desafio de avaliar este tipo de abordagem preventiva através de dados clínicos. 
Correlações positivas entre o nível de infecção por Sm e o incremento de cárie são freqüentemente encontrados em estudos longitudinais ${ }^{125}$. Raramente indivíduos com baixas contagens de Sm apresentam alta incidência de cárie e pessoas livres de cárie podem ser encontradas em todos os níveis de infecção por $\mathrm{Sm}^{109}$

O Sm apresenta colonização localizada na dentição e a quantidade de Sm na saliva está relacionada ao número de superfícies dentárias colonizadas, sugerindo que muitas superfícies estão sujeitas a um aumentado risco de cárie quando as contagens de Sm na saliva são altas. O nível de infecção do bebê por Sm pode ser justificado pela susceptibilidade à colonização, pela freqüência e dose de inoculação e principalmente pelo consumo de sacarose. No entanto, uma forte associação com a doença não significa necessariamente um bom valor de predição e THYSTRUP; FEJERSKOV ${ }^{109}$ questionam a utilidade da determinação do nível de Sm na saliva materna como fator de predição da experiência de cárie dos bebês.

A eficácia dos preditores considerada isoladamente é limitada e devese buscar a combinação de informações, contudo em qualquer programa de triagem haverá falha na identificação de pessoas com risco, podendo serem excluídos indivíduos com risco verdadeiramente alto e incluídas pessoas com baixo risco real. Para se decidir se um grupo necessita de medidas preventivas intensificadas 0 exame clínico é a fonte de informação mais importante ${ }^{76,109}$.

As gestantes selecionadas para este estudo apresentaram um número mínimo de 3 superfícies dentárias lisas (vestibular, lingual ou proximais) com lesões de cárie manifestas. Porém, o número médio de superfícies cariadas foi bastante elevado $(13,98)$, tornando-se mais expressivo ainda quando somado às lesões 
iniciais, atingindo um valor médio de 19,92 superfícies acometidas pela cárie (Tabela 6 e Figuras 4 a 7$)$.

O forte "peso" do componente cariado na composição do índice CPOS $(43,88 \%)$ e a expressiva contribuição do componente perdido neste grupo ainda muito jovem revela o acesso limitado da população de baixa renda a um padrão de atendimento odontológico predominantemente curativo (mutilador).

O critério para se considerar a experiência de cárie alta é arbitrário. Indivíduos com elevado número de lesões em populações com baixa incidência da doença podem ser considerados bem sucedidos em populações com alta incidência de cárie.

Com relação ao índice CPO seu valor preditivo é limitado em adultos, pois a experiência acumulada de cárie permanece alta a despeito das variações de exposição aos fatores de risco que possam vir a ocorrer. Por isso utilizamos o critério seletivo de lesões ativas, tanto manifestas como incipientes.

A divisão das pacientes entre os grupos EX e CT foi aleatória, porém os grupos mostraram-se homogêneos com relação a todos os dados obtidos no início do estudo (baseline), o que pode ser verificado nas Tabelas 1 a 7 , e Tabela 13. Esta homogeneidade com relação às condições sócio-econômicas e clínicas é fator favorável à análise dos resultados.

Os índices CPOS e SC, e o número de desmineralizações ativas das pacientes apresentaram grande variação individual: 4 a 113 para o índice CPOS, 4 a 41 para o componente SC e 0 a 20 para as desmineralizações (Tabela 6). No grupo Controle houve maior concentração de pacientes na faixa de 10 a 15 superfícies cavitadas e no grupo Experimental na faixa de 4 a 9 superfícies. No 
entanto, cinco pacientes, todas do grupo Experimental, apresentaram mais de 25 superfícies cavitadas (Figura 4).

Estas disparidades na prevalência de cárie foram comparadas estatisticamente, pois poderiam ter correlação com a incidência da doença nas mães e nos bebês. O número de lesões iniciais poderia inclusive ter maior correlação com o incremento futuro de lesões do que os índices CPOS e SC ${ }^{109}$.

Observando as Tabelas 7 e 8 e a Figura 8 notamos que os grupos EX e CT não diferiram estatisticamente em relação a experiência anterior de cárie, nem em relação ao incremento de novas lesões. Embora o número médio de lesões de mancha branca tenha sido superior no grupo CT, estando próximo da diferença estatística.

Independentemente do grupo, analisamos a possível correlação entre a experiência anterior de cárie e o incremento de novas lesões na dentição materna (Tabela 9), o que nos revelou que o número de lesões ativas no "baseline" correlacionourse positivamente com o incremento observado durante os 2 anos do estudo, mostrando que o exame clínico pode ser um bom preditor de risco.

Um número significativamente maior de novas cavidades em superfície lisa foi observado nas pacientes que apresentavam um número de lesões de mancha branca também mais alto no início do estudo. Podendo este fato ser decorrente da formação de cavidade das desmineralizações previamente diagnosticadas, devido a manutenção de um comportamento de risco.

O índice SC também mostrou correlação com o incremento de novas cavidades de fissura. 
Correlacionamos a experiência anterior de cárie da mãe com a prevalência da doença nos bebês (Tabela 10) e identificamos que as médias dos índices analisados foram bastante próximas entre si e distantes da significância estatística.

ALALUUSUA; MALMIVIRTA ${ }^{8}$ também não conseguiram estabelecer relação significativa entre o CPOD materno e a experiência de cárie das crianças com 36 meses, porém relataram uma tendência de se encontrar uma prevalência maior de crianças livres de cárie quando o CPOD era baixo $(<12)$ do que quando era alto ( $>23$ ), $90 \% \times 70 \%$ respectivamente.

A conversão do índice CPOS para o índice CPOD em nosso estudo resultou em um valor médio próximo a 14. Este valor é classificado como baixo por ALALUUSUA; MALMIVIRTA ${ }^{8}$ mas os autores não relatam especificamente o componente cariado, o qual em nosso estudo foi de 9,0 dentes, o que pode ainda estar subestimado tendo em vista que não lançamos mão de recursos adicionais de diagnóstico como a transiluminação por fibra óptica e radiografias, ambos empregados no referido trabalho.

SODERLING et al $^{104}$ relataram um CPOD médio de 18 para as gestantes por eles estudadas na Finlândia, porém não fazem referência ao componente cariado, nem a lesões incipientes.

$\mathrm{Na}$ seqüência de estudos de WRIGTH et $\mathrm{al}^{123}$ as pacientes apresentavam um CPOS médio de 34 e um correspondente CPOD de 16 (utilizaram radiografias), com uma média de 16,4 superfícies que exigiram tratamento restaurador (8,7 superfícies proximais e 7,7 oclusais). Valores próximos aos nossos: CPOS 32; CPOD 14; CD 9,0; SC 14. 
KOHLER em sua seqüência de estudos ${ }^{58-62}$ não faz referência à prevalência de cárie na dentição materna. Porém, BRAMBILA et al ${ }^{20}$ constataram um CPOD médio de 12,5 em gestantes pré-selecionadas através de contagem de Sm superior a $10^{5}$ UFC / $\mathrm{mL}$ de saliva estimulada, embora o número médio de dentes cariados tenha sido inferior ao nosso: $1,4 \times 9,0$. GUNAY et al ${ }^{44}$ relataram um CPOD de 14,5 e um correspondente CPOS de 46,4, no entanto apenas 8 das 54 pacientes estudadas apresentavam lesões de cárie ativas.

Portanto, podemos notar que a prevalência de cárie do nosso grupo não se distancia das observadas em outros estudos realizados com gestantes com altas contagens de Sm.

Se por um lado não identificamos correlação entre a experiência anterior de cárie na dentição materna e a incidência da doença nas crianças; por outro, a atividade da doença, avaliada através do incremento de novas lesões durante o desenvolvimento da abordagem preventiva mostrourse fortemente associada com a experiência de cárie dos bebês $(p=0,0009)$.

O grupo de mães em cujos filhos foi diagnosticada a presença de cárie apresentou um incremento de lesões de cárie significativamente maior do que o grupo de mães de bebês sem cárie (Tabela 11 e Figura 9). A diferença observada entre os grupos deveu-se principalmente ao incremento em superfícies lisas ocorrido durante o primeiro ano do estudo (Tabela 12). O grupo de mães de bebês cárieativos também apresentou um acúmulo de placa superior, embora não tenha sido observada diferenças significantes entre os outros índices (ICNTP, CTS ), Tabela14.

$\mathrm{Na}$ avaliação de 12 meses constatourse que 20\% das mães do grupo EX e 17\% do grupo CT não apresentaram incremento de cárie. Na avaliação de 24 
meses $32,4 \%$ das pacientes do grupo EX e $20 \%$ das pacientes do grupo CT não apresentaram novas lesões. No entanto, apenas 2 pacientes, ambas do grupo CT, mantiveram-se sem cárie durante todo o estudo. Para os dois grupos (EX e CT) o incremento de cárie foi maior no primeiro ano do que no segundo ano do estudo. Com referência às mães de bebês cárie-ativos, todas apresentaram incremento durante o primeiro ano do estudo, e na avaliação de 24 meses duas mães do grupo EX não tiveram incremento de lesões.

Embora nossa atuação tenha sido mais intensa no grupo Experimental, que recebeu, além da abordagem preventiva, adequação bucal com cimento de ionômero de vidro e aplicações tópicas semestrais de flúor gel 1,23\% e de solução anti-microbiana a base de iodo, pôde-se constatar que os dois grupos se comportaram de maneira similar com relação ao incremento de cárie (Tabela 8 e Figura 8). Porém, os valores numéricos foram sempre superiores para o grupo Controle, onde constatourse a presença de 85 novas cavidades, sendo 46 em superfícies lisas, contrapondo-se a 73 novas lesões diagnosticadas (32 em superfícies lisas) no grupo Experimental, apesar deste contar com um número maior de pacientes.

A reversão do risco à cárie não é meta facilmente atingida, e, assim como neste estudo, no estudo de KOHLER et al ${ }^{62}$ observou-se que a instituição de um tratamento preventivo básico foi eficaz na redução da população de bactérias cariogênicas de $60 \%$ de sua amostra. As demais pacientes tiveram de ser submetidas a um regime antimicrobiano intenso e repetitivo e em muitas delas o nível de Sm não pôde ser controlado, sendo que 62\%, 26\% e 23\% das mães recuperaram suas contagens iniciais nas avaliações de 15, 23 e 36 meses, 
respectivamente, o que ilustra as dificuldades de uma abordagem preventiva em grupos de alto risco, mesmo em países que se encontram mais adiantados mo que se refere ao controle da doença cárie a nível populacional.

Com exceção do trabalho de GUNAY et $\mathrm{al}^{44}$, em nenhum dos estudos que abordaram o efeito de medidas preventivas direcionadas às mães na experiência de cárie de seus filhos, o incremento de lesões de cárie na dentição materna foi considerado. O risco de cárie da mãe foi avaliado unicamente através do monitoramento microbiológico.

No trabalho de GUNAY et l $^{44}$ não se utilizou o nível de infecção por Sm como item para seleção da amostra. As gestantes foram selecionadas aleatoriamente, embora $40 \%$ apresentasse contagens superiores a um milhão de UFC / $\mathrm{mL}$ de saliva. Ao final do estudo apenas $22 \%$ das pacientes encontravam-se nesta situação, e apenas 2 pacientes apresentaram incremento de novas lesões. Os resultados de GUNAY et $\mathrm{al}^{44}$ foram excelentes também com relação às crianças, pois a incidência de cárie aos 3 anos foi nula, contrapondo-se a uma prevalência de $18,5 \%$ observada no grupo controle.

ZICKERT; EMILSON; KRASSE ${ }^{125}$ observaram uma significativa diminuição da atividade de cárie em adolescentes suecos com alto nível de infecção por Sm, submetidos a um regime anti-microbiano com clorexidina idêntico ao instituído por KOHLER et $\mathrm{al}^{62}$. Os autores relataram o incremento de cárie , tanto lesões manifestas como incipientes, por um período de 3 anos. $\mathrm{O}$ incremento médio de superfícies com novas lesões / ano observado no estudo foi de: 2,46; 2,37; e 6,93 para os subgrupos controle com contagens baixa, média e alta de Sm no início do 
estudo, respectivamente. Para os subgrupos teste encontraram os seguintes valores médios: 1,$2 ; 1,73 ; 1,3$.

Em nosso estudo, utilizamos um método de diagnóstico clínico bastante similar ao estudo de ZICKERT; EMILSON; KRASSE ${ }^{125}$ e encontramos um incremento médio de lesões de 3,12 e 2,57 superfícies/ ano para os grupos CT e EX, respectivamente. Valores próximos aos observados por ZICKERT; EMILSON; KRASSE $^{125}$ para os subgrupos controle com contagens baixa e intermediárias de Sm e valores superiores aos encontrados em todos os subgrupos teste. Comparando-se os grupos de mães de bebês cárie-ativos com o grupo de mães de bebês sem cárie encontramos um incremento médio anual de 4,67 e 2,26, respectivamente. Nota-se que o grupo de mães de bebês cárie ativos apresentou um incremento próximo ao observado para o subgrupo controle com alta contagem inicial no estudo de ZICKERT; EMILSON; KRASSE ${ }^{125}$.

Com relação aos índices complementares (PHP, ICNTP e CTS) os EX e CT mostraram-se homogêneos no início do estudo e assim continuaram, não sendo observada diferença estatística em nenhuma avaliação (Tabela 13). impacto da abordagem preventiva e da adequação bucal sobre estas variáveis também foi similar entre os grupos EX e CT (Tabela 15). As variáveis PHP e ICNTP apresentaram sensível redução na avaliação de 6 meses, o que provavelmente foi decorrente dos procedimentos de profilaxia, raspagem e instruções de higiene oral, porém retornaram aos seus valores iniciais na avaliação de 24 meses.

A capacidade tamp salivar diferiu a cada avaliação, apresentando valores crescentes em ambos grupos o que pode ter ocorrido como conseqüência de uma melhora no padrão de saúde bucal, o que não é confirmado pelo 
comportamento das outras variáveis; mas também pode ser decorrente de alterações encontradas nos componentes salivares durante a gestação, que possivelmente interfiram na capacidade tampão da saliva, o que estaria em concordância com os estudos de LAINE ${ }^{65,66}$ e de SALVOLINI et al ${ }^{95}$.

O fluxo salivar mostrou-se normal em 47 pacientes, e 8 pacientes apresentaram fluxo insatisfatório (> 0,7 $\mathrm{mL}$ saliva / $\mathrm{min}$ ) nas três coletas (baseline, 6 meses, 24 meses). Nas demais pacientes (9) houve uma miscigenação de resultados, tendo o fluxo ora atingido valores normais, ora sendo insatisfatório. $\mathrm{O}$ valor de risco $(0,7 \mathrm{~mL} / \mathrm{min})$ foi estabelecido segundo as orientações de THYLSTRUP; FEJERSKOV ${ }^{109}$ que relatam risco aumentado à cárie em indivíduos com fluxo abaixo deste valor.

Analisamos a correlação entre o fluxo salivar e o incremento de cárie materno, e observamos que embora não tenha sido atingida significância estatística, a presença constante de um fluxo insatisfatório (nas 3 avaliações) contribuiu para um superior incremento médio de lesões (Tabela 17 ).

A abordagem experimental mostrou-se de grande valia na redução ou retardo da manifestação de cárie nos bebês.

Não encontrou-se justificativa para implementação de flúor pré-natal como medida preventiva adicional ${ }^{38,117}$.

A prevalência de crianças cárie-ativas foi superior no grupo Controle quando comparada ao Experimental $(33,33 \% \times 14,75 \%$, respectivamente) atingindo um nível próximo a significância estatística (Tabela 19).

A maneira pela qual as crianças foram acometidas pela doença também foi mais severa no grupo Controle (Tabela 20 e Figura 10), embora não 
tenha sido observada diferença estatística, provavelmente pelo pequeno número de crianças cárie-ativas. No grupo Controle dos dez bebês cárie ativos, cinco apresentaram mais de 6 superfícies dentárias com lesões cariosas, o que não foi observado em criança alguma do grupo Experimental. Das 65 superfícies com lesões incipientes, 52 foram diagnosticadas em crianças do grupo Controle e das 14 superfícies dentárias com cavidade, 11 estavam presentes nos bebês Controle.

SODERLING et al $^{104}$ também encontraram diferença na prevalência de Sm entre os filhos de mães submetidas a diferentes regimes profiláticos, embora entre elas não tenham sido evidenciadas alterações significativas nas contagens de Sm. Sugeriram que o consumo diário de xilitol teria alterado as propriedades de aderência dos microorganismos, diminuindo suas chances de sucesso de implantação. A dieta das crianças não foi analisada, mas sabe-se que tem influência marcante na primo-colonização.

Em nosso estudo o comportamento clínico do cimento de ionômero de vidro foi significativamente melhor do que o desempenho do cimento de óxido de zinco e eugenol IRM nas avaliações de 1 e 2 anos (Tabelas 39 e 40). Após 24 meses, $90,63 \%$ das restaurações de cimento de ionômero de vidro foram consideradas clinicamente satisfatórias (Tabela 34), enquanto já na avaliação de 12 meses aproximadamente $74 \%$ das restaurações Classe I e $85 \%$ das restaurações Classe II realizadas com cimento IRM mostraram-se insatisfatórias (Tabela 35), contrariando os resultados apresentados por JENDRESSEN; PHILLIPS $^{49}$ e JENDRESSEN et al ${ }^{50}$ em 1969.

O desgaste generalizado e a fratura da restauração e/ou dente, ambos levando à perda da restauração foram as falhas clínicas encontradas com mais 
freqüência para o cimento IRM (Tabela 47 e Figura 16). Ocasionando exposição dos tecidos dentinários, recidivas de cárie e sensibilidade ou envolvimento pulpar. Esta situação favoreceu a formação de nichos para a colonização bacteriana, diminuindo a eficácia dos procedimentos de higiene bucal e a motivação das pacientes.

Embora as necessidades urgentes (relacionadas a dor ou ao risco de envolvimento pulpar) tenham sido supridas através de novas restaurações, a condição bucal do grupo Controle no que se refere ao procedimento de adequação, apresentou-se muito menos favorável à observada no grupo Experimental, no qual o pequeno número de falhas do material restaurador permitiu o reparo das restaurações e a escariação e selamento das novas cavidades em tempo hábil.

WRIGHT et al ${ }^{123}$ constatou uma redução significativa, porém transitória (aproximadamente 2 meses) na contagem de microorganismos cariogênicos após realização de tratamento restaurador convencional em um grupo de gestantes com grande necessidade restauradora. Justifica seu resultados pela remoção de tecido infectado e substituição deste por um material inerte, afetando o habitat dos microorganismos e facilitando a higienização. E atribuem a rápida recolonização por $\mathrm{Sm}$ à rugosidade superficial dos materiais restauradores e à morosidade do tratamento restaurador convencional (aproximadamente 90 dias), permitindo que a recolonização superasse a redução microbiana causada pela atuação curativa. Sugerem tratamentos restauradores de alta intensidade e curta duração utilizando materiais menos favoráveis à recolonização bacteriana.

Acreditamos que o procedimento de adequação bucal com cimento de ionômero de vidro realizado no grupo Experimental tenha sido coerente com o proposto por WRIGTH et al ${ }^{123}$. 
A resina composta Fill Magic utilizada nas restaurações Classe III, IV e V no grupo Controle apresentou um excelente resultado clínico (Tabelas 37 e 38), com 93,56\% de sucesso após dois anos, comparável ao desempenho do cimento Fuji IX (Tabelas 41 e 42).

Porém, a técnica restauradora para resina é mais sensível às condições ambientais (isolamento relativo) do que a técnica requerida pelo cimento Fuji IX, especificamente desenvolvido para ser empregado na técnica de restauração atraumática $^{51}$, e a matriz resinosa parece ser mais favorável ao crescimento bacteriano $^{76,106}$. Embora, a viabilidade da resina como material de escolha em procedimentos restauradores de mínima intervenção tenha sido sugerida por alguns autores $^{27}$.

Os resultados aqui encontrados sustentam o uso do cimento de ionômero de vidro para procedimentos de adequação bucal em populações com alta atividade de cárie e desprovidas de atenção odontológica convencional, pois o desempenho clínico do material testado foi encorajador e comparável às avaliações clínicas relatadas em estudos sobre a técnica restauradora atraumática ${ }^{27,51,83}$.

Contudo, devemos salientar que o procedimento de adequação bucal difere da proposta do tratamento restaurador atraumático, sendo que o primeiro é considerado uma etapa de transição e o segundo um programa de controle de cárie de caráter "permane nte" 87.

A literatura pertinente também se mostra bastante cautelosa em recomendar a técnica restauradora atraumática sem restrições e sua efetividade a longo prazo é questionada, pois, a despeito das propriedades anicariogênicas do 
cimento de ionômero de vidro, a manutenção proposital de tecido dentinário cariado ainda é assunto de controvérsia $27,51,72,82,83,103,120$.

No grupo Experimental também foi instituído um regime de aplicações de solução de iodeto de potássio e fluoreto de sódio imediatamente após a finalização da adequação bucal (gestação), e nas reavaliações de 6 e 12 meses, períodos nos quais os bebês se encontravam com idades entre 5 a 9 meses e 12 a 16 meses, respectivamente. Na primeira reavaliação (6 meses) $50 \%$ das crianças encontravam-se edêntulas. Na segunda reavaliação aproximadamente $53 \%$ das crianças ainda não apresentavam os primeiros molares decíduos (Tabela 18).

Segundo CAUFIELD; CUTTER; DASANAYAKE ${ }^{24}$ haveria um período finito de máxima probabilidade de aquisição de Sm denominado janela de infectividade entre as idades de 19 e 31 meses. Estando este período diretamente relacionado com o irrompimento dos dentes decíduos e sendo os primeiros molares particularmente críticos para o sucesso de implantação do Sm. Portanto as abordagens preventivas direcionadas as mães deveriam anteceder este momento. Porém, a universalidade da janela da infectividade nas populações humanas ainda não está determinada, sendo questionada por alguns autores ${ }^{104}$, e provavelmente a aquisição ocorra em idade mais precoce em populações com alta prevalência da doença.

Dando continuidade ao estudo de WRIGTH et al ${ }^{123}$, DASANAYAKE et $\mathrm{al}^{32}$ implementou um regime antimicrobiano às mães de seu grupo teste no momento de erupção do primeiro dente do bebê. A solução utilizada por DASANAYAKE et $\mathrm{al}^{32}$ durante dias alternados por um período de duas semanas foi a mesma empregada em nosso estudo. Imediatamente observou-se redução 
significativa nas contagens de Sm e Lb na saliva das mães, porém a recuperação da microbiota foi rápida (menos de três meses) e o regime antimicrobiano não influenciou a aquisição de Sm pelas crianças, sendo a prevalência de cárie das crianças do grupo teste superior a do grupo controle com a idade de 2 anos (17\% e $4 \%$, respectivamente) e 3 anos. Especulam que o momento de aplicação da solução foi muito precoce e deveria ter sido repetida durante a erupção dos primeiros molares.

Em nosso estudo a solução de iodo foi aplicada nos momentos sugeridos por DASANAYAKE et $\mathrm{al}^{32}$ e pode ter atuado como fator coadjuvante na menor experiência de cárie dos bebês do grupo Experimental.

Poderíamos aqui justificar a segunda hipótese por nós proposta, onde constatamos que a intensidade (ou o tipo) da abordagem preventiva direcionada às mães associa-se de forma significativa com uma menor experiência de cárie em seus filhos.

Dos trabalhos consultados pôde-se concluir que o uso do iodo como quimioterápico apresenta efeito transitório sobre a microbiota cariogênica, e a concentração da solução, a duração e a freqüência de aplicação parecem influenciar os resultados ${ }^{23,57,85}$. Notou-se que a solução utilizada foi de difícil armazenagem, pois, se não consumida imediatamente, observava-se a reação entre o flúor e o vidro ambar. Também houve relato de duas pacientes com possíveis reações de sensibilidade ao iodo (ardor intenso e vômitos).

Quimioterápicos mais potentes como a clorexidina também têm seu efeito residual influenciado pela dieta e hábitos dos pacientes. Regimes semestrais 
de aplicação de clorexidina em gestantes com altas contagens de Sm mostraram-se ineficazes em alterar de forma significativa a colonização dos bebês ${ }^{104,108}$.

Regimes mais intensos como o executado por $\mathrm{KOHLER}^{58,59,61,62}$ mostraram-se efetivos na diminuição das contagens maternas de Sm, o que repercutiu favoravelmente nos filhos, pois observaram um retardo na primo-infecção e uma menor experiência de cárie no grupo experimental.

$\mathrm{Na}$ seqüência de estudos de $\mathrm{KOHLER}^{58,59,61,62}$ ficou claro que as medidas preventivas direcionadas às mães foram efetivas e tiveram um efeito residual de longo prazo, mesmo após sua descontinuidade. Constatou-se também forte associação entre o nível de infecção da fonte inoculadora e a precocidade da primo-infecção e entre esta e a experiência futura de cárie das crianças (tanto em termos de prevalência como de severidade da doença).

A comparação de resultados observados em diferentes estudos deve ser feita analisando-se as diferenças metodológicas, que vão desde variáveis distintas na seleção da amostra até o regime profilático empregado.

Nos estudos de KOHLER ${ }^{58,59,61,62}$ o nível de infecção por Sm das mães foi superior ao valor de seleção do estudo de DASANAYAKE et al ${ }^{32}$, porém a coleta de saliva também foi diferente. Valores intermediários de risco foram estabelecidos nos estudos de TENOVUO et $\mathrm{al}^{108}$, BRAMBILA et $\mathrm{al}^{20}$ e SODERLING et $\mathrm{al}^{104}$. Já GUNAY et al $^{44}$ não pré-estabeleceram nível de infecção por Sm para seleção de seu grupo.

KOHLER et a ${ }^{62}$ instituíram um regime quimioterápico mais pesado do que o de DASANAYAKE et al ${ }^{32}$, no entanto, no primeiro estudo o grupo controle não recebeu benefício algum, enquanto no segundo ambos grupos receberam 
tratamento restaurador. Já no estudo de BRAMBILA et al ${ }^{20}$ nenhum dos grupos recebeu tratamento restaurador e a atuação entre os grupos diferiu apenas no regime antimicrobiano. Nos estudos de SODERLING et $\mathrm{al}^{104}$ e TENOVUO et $\mathrm{al}^{108} \mathrm{o}$ tratamento das lesões ficou sob responsabilidade do sistema de saúde nacional filandês e no estudo de GUNAY et $\mathrm{al}^{44}$, na evidência de necessidade restauradora a paciente era aconselhada a procurar seu dentista.

Em nosso estudo a abordagem diferiu entre os grupos quanto ao uso de antimicrobianos (flúor e iodo com profilaxia prévia) e no material empregado para adequação bucal.

Nos estudos de BRAMBILA et $\mathrm{al}^{20}$ e KOHLER et $\mathrm{al}^{62}$ foram identificadas alterações no nível de infecção por Sm nas mães e o retardo na primoinfecção dos bebês ${ }^{20,58,59,61}$. Porém, no estudo de BRAMBILA et $\mathrm{al}^{20}$, o regime de bochechos diários (flúor e clorexidina) realizado durante o último trimestre de gestação teve um efeito de longa duração e crescente, o que nos parece discutível.

No estudo de SODERLING et $\mathrm{al}^{104}$, assim como no nosso, constatouse que regimes profiláticos distintos não apresentaram diferença estatística no risco/atividade de cárie das mães, porém influenciaram significativamente a aquisição de microbiota cariogênica e a experiência de cárie de seus filhos.

Os dentes recém irrompidos representam um habitat virgem onde o Sm tem sua implantação facilitada sem a competição de outras bactérias indígenas já estabelecidas. Provavelmente o Sm enfrente dificuldades de implantação mais tardia, o que é suportado pela dificuldade de implantação deste microorganismos na boca de adultos ${ }^{24}$. 
Com relação ao exposto acima encontramos um fato interessante com relação ao incremento de cárie. Os terceiros molares recém-irrompidos durante o estudo ( $75 \%$ das pacientes com menos de 21 anos) contribuíram com $23,42 \%$ das novas cavidades e $29,19 \%$ das lesões iniciais diagnosticadas. Percentual consideravelmente alto que poderia ser justificado por representarem um habitat virgem e favorável à colonização microbiana predominante no ambiente bucal, de forma similar a ocorrente com a dentição decídua de seus filhos.

Ratificando a maior susceptibilidade do esmalte não completamente maturado, associada à retenção de placa (infra-oclusão e área de difícil higienização) em ambiente hostil, ou seja, com grande exposição aos fatores de risco.

A prevalência de bebês cárie-ativos em nosso grupo Experimental mostrourse próxima aos valores encontrados por DASANAYAKE et a ${ }^{32}$ em seu grupo teste (17\%) e aos valores relatados para crianças com 3 anos do grupo teste de KOHLER; ANDREEN; JONSSON ${ }^{59}$ (16\%). E contrasta com a ausência de crianças cárie ativas com a idade de dois anos nos estudos de TENOVUO et al ${ }^{108} \mathrm{e}$ GUNAY et a ${ }^{44}$.

Considerando-se levantamentos epidemiológicos de diferentes regiões, notamos que a prevalência de crianças cárie-ativas em nosso grupo Controle $(33,33 \%)$ foi semelhante à relatada WALTER; FERELLE; ISSAO ${ }^{118}$ em crianças brasileiras com idades entre 19 e 24 meses $(32,4 \%)$ e a de imigrantes latinos dos Estados Unidos ${ }^{81}$. Sendo ainda superior à prevalência observada por MATTOSGRANER et $\mathrm{al}^{74}$ em Piracicaba (24\%) e inferior a prevalência de populações 
altamente afetadas pela cárie precoce da infância (Indoneses $48 \%$ e indígenas americanos e esquimós $70 \%)$.

Apesar de grande variação na prevalência de cárie na primeira infância entre diversos países ou regiões, as publicações são consistentes em identificar a existências de grupos de polarização altamente afetados pela doença ${ }^{74,121,122}$ que necessitam de identificação precoce e do estabelecimentos de atuação preventiva intensificada.

Nesta pesquisa, assim como nos estudos de ALALUUSUA; MALMIVIRTA $^{8}$ e de MATTOS GRANER et $\mathrm{al}^{75}$, identificou-se uma associação significativa entre a presença de placa nas superfícies vestibulares dos incisivos superiores decíduos e a experiência de cárie (incidência) aos 24 meses, sendo que aos 12 meses já se notava alta prevalência de crianças com acúmulo de placa no grupo que veio a se apresentar cárie-ativo. (Tabelas 21 e 22).

Acreditamos que esta variável seja de importância significativa para a triagem de crianças de risco em idade precoce (1 ano), principalmente a nível populacional, estando ao alcance do clínico.

Nas Tabelas 24 e 25 correlacionamos a atividade de cárie das crianças com a higiene oral relatada pelas mães e não encontramos significância, o que está de acordo com o exposto por THYSTRUP; FEJERSKOV ${ }^{109}$ e BELINI; ARNEBERG; VONDERFEHR ${ }^{11}$ que enfatizam a importância da higiene oral em termos de efetividade de limpeza e não de freqüência de escovação. O relato da mãe freqüentemente diferiu da observação clínica. Na avaliação de 24 meses, das 42 crianças que, segundo a mãe, tinham seus dentes escovados pelo menos uma vez ao dia, 22 apresentaram placa visível na vestibular dos incisivos, o que sugere uma 
técnica inadequada de limpeza. Na verdade, a total remoção de placa através de meios mecânicos em crianças menores de dois anos dificilmente é alcançada ${ }^{116}$.

O padrão de amamentação foi avaliado quanto ao tipo de aleitamento (materno ou leite de origem animal, puro ou adoçado) e quanto à freqüência de mamadas noturnas com as idades de 12 e 24 meses (Tabelas 26, 27e 28).

A mamadeira foi considerada adoçada quanto continha sacarose (açúcar refinado), mel, ou achocolatados, farináceos ou fórmulas lácteas que contivessem em sua formulação açúcar. Na avaliação de 6 meses 15 crianças eram amamentadas exclusivamente no peito, 35 usavam apenas a mamadeira $(55 \%)$ e 14 tinham um padrão misto de aleitamento. Indicando um desmame precoce para a maioria dos bebês. Todas as mães que ofereciam a mamadeira adicionavam açúcar ou outro complemento contendo açúcares.

Na avaliação de 12 meses 9 bebês eram amamentados (14\%), exclusivamente ou predominantemente, e 55 faziam uso exclusivo de mamadeira. $\mathrm{Na}$ Tabela 26 comparou-se o tipo de aleitamento com a atividade de cárie das crianças e não se encontrou diferença estatística. O leite é um alimento complexo, possuindo componentes cariogênicos (lactose) e anti-cariogênicos (caseína), sendo o primeiro encontrado em maior quantidade no leite humano e o segundo em maior quantidade no leite de vaca ${ }^{67}$.

Apesar da maior concentração de lactose, o aleitamento materno é vantajoso do ponto de vista de prevenção da cárie por retardar o contato com a sacarose, visto que a grande maioria da mamadeiras são adoçadas ${ }^{67}$. Segundo WALTER; FERELLE; ISSAO ${ }^{118}$ este percentual atinge $95 \%$, valor comparável ao identificado em nosso estudo, onde $100 \%$ das mães que ofereciam mamadeira a 
seus filhos na avaliação de 12 meses informaram adicionar sacarose ou outro tipo de complemento contendo açúcar a esta, a despeito das orientações dadas no estudo.

$\mathrm{Na}$ avaliação de 24 meses constatou-se que 6\% dos bebês ainda eram amamentados, apenas um de forma exclusiva, e não foi observada associação entre o tipo de aleitamento e a experiência de cárie (Tabela 27).

O padrão de amamentação identificado em nosso estudo foi extremamente parecido ao relatado por WALTER; FERELLE; ISSAO ${ }^{118}$, que observaram que a amamentação exclusivamente materna dura em média dois meses, a mista 4 meses e aos seis meses apenas um terço dos bebês continuam com o aleitamento natural. A partir daí o uso da mamadeira doce é muito freqüente (95\%).

O uso da mamadeira adoçada durante o sono e o desmame tardio são apontados como fatores de risco da cárie precoce da infância ${ }^{26,81}$, até pouco tempo referida como cárie de mamadeira. O padrão alimentar abusivo é particularmente maléfico durante a primeira infância devido à alta freqüência de ingestão, ao tempo prolongado de permanência do substrato na boca e ao momento de uso ${ }^{62}$.

Durante o sono o fluxo salivar e os reflexos de deglutição estão extremamente diminuídos e os fatores de proteção do leite são insuficientes para equilibrar a queda de pH promovida pela metabolização da lactose, o que sugere a cariogenicidade deste alimento, tanto humano como bovino, se não associado à higiene oralp2.

Na Tabela 28 verifica-se a análise da freqüência de mamadas durante o sono (noturno ou diurno) nos grupos de bebês com e sem cárie. Apesar de não ter 
sido identificada significância estatística, pode-se notar que tanto no período de 12 como de 24 meses os valores médios de freqüência de ingestão foram superiores para o grupo de bebês cárie-ativos.

A prevalência e o número médio de mamadas durante o sono foi decrescente com a idade para a amostra como um todo. Dos 15 bebês cárie ativos, 05 tomavam mamadeiras doces durante o sono com 12 meses, e uma criança era amamentada no peito durante a noite toda, até a idade de 24 meses. Nas demais crianças cárie-ativas o hábito da amamentação noturna foi negado pela mãe.

No entanto, a cárie resulta da associação de vários fatores de risco e está relacionada a hábitos da vida diária. O uso impróprio da mamadeira ou do aleitamento é apenas parte de um problema de estilo de vida inadequado, pois em geral os bebês cárie-ativos também não têm seus dentes escovados e ingerem sacarose várias vezes ao dia ${ }^{7,26,62}$.

O contato precoce com a sacarose é bastante comum na população brasileira. Segundo WALTER; FERELLE; ISSAO ${ }^{118}$ com um mês de idade cerca de $60 \%$ dos recém-nascidos já haviam entrado em contato com a sacarose e aos 12 meses $100 \%$ ingeria sacarose com freqüência. De forma coerente com o relatado acima, nós observamos que aos 6 meses 79,7\% dos bebês já haviam entrado em contato com a sacarose e que aos 12 meses o consumo diário de sacarose esteve presente em $100 \%$ da amostra. A introdução de uma dieta cariogênica aos 6 meses de idade foi observada em $86,7 \%$ dos bebês cárie ativos e em $77,6 \%$ dos bebês sem cárie.

O padrão alimentar das crianças, no que se refere à ingestão de sacarose, foi relatado através de questionário aplicado nas avaliações de 6, 12 e 24 
meses, onde tentourse identificar a freqüência de ingestão de alimentos cariogênicos comumente oferecidos às crianças como balas, chicletes, pirulitos, bolachas, chocolate, refrigerantes, iogurtes e similares. Porém, a dieta não foi avaliada como um todo e sua correlação com a experiência de cárie das crianças não foi analisada. Procuramos através do questionário identificar o momento de primeiro contato com a sacarose e a presença desta na alimentação diária dos bebês.

$\mathrm{Na}$ abordagem inicial das gestantes também obtivemos informações sobre a dieta delas através da distribuição de questionários de quatro dias ,conforme proposto por $\mathrm{KIDD}^{54}$. Porém as pacientes encontraram dificuldades para 0 preenchimento do mesmo.

Dos 81 questionários distribuídos 33 não foram devolvidos. A qualidade e detalhamento no preenchimento dos questionários variou muito. O número médio foi de cinco ingestões diárias de alimentos contendo sacarose entre as refeições. Devido às inconsistências observadas nos questionários, os mesmos foram utilizados apenas para a orientação individual quanto à dieta, tendo como base os dados por elas fornecidos, objetivando-se a visualização concreta do alto consumo de açúcar. KOHLER et $a^{62}$ também relataram difiuldade em se obter informaçôes precisas e seguras através de questionários de dieta.

Considerando-se o baixo poder aquisitivo da população estudada e a alta prevalência de uma dieta desequilibrada, o que ratifica os achados de NASCIMENTO; LOPES ${ }^{84}$, não foi nosso intuito restringir totalmente o consumo de sacarose, mas sim recomendar às pacientes que concentrassem o consumo de açúcar após as principais refeições, nunca antes de dormir, e que a higiene bucal 
deveria ser feita imediatamente após a ingestão de açúcares. As pacientes foram orientadas a terem uma dieta balanceada, com grande ingestão de proteínas e vegetais e receberam informações quanto aos grupos de alimentos freqüentemente ingeridos.

A importância dos tipos de alimentos ingeridos e a freqüência e os horários de ingestão foram orientações de rotina no estudo, ratificadas a cada avaliação, porém sua repercussão sobre a amostra parece ter sido pequena, independentemente do grupo.

A perda da amostra em nosso estudo foi de $21 \%$ no período de 2 anos. Todo esforço foi feito no sentido de se manter o grupo inicial, envolvendo inclusive repetidas visitas domiciliares às pacientes faltosas. No entanto das 81 pacientes que efetivamente iniciaram o estudo, 2 perderam os seus bebês, uma devido à prematuridade e outra devido ao contágio da criança por meningite. As demais não puderam ser localizadas devido à mudança de endereço, cidade ou informação de endereço errada.

KOHLER et al $^{62}$ também iniciaram seu estudo com 81 pacientes e tiveram uma perda de $7 \%$ aos 23 meses. BRAMBILA et $a^{20}$ iniciaram seu estudo com 65 pacientes, número similar ao nosso número de pacientes remanescentes. DASANAYAKE et $a^{32}$ terminaram seu estudo com 48 pacientes, aproximadamente $77 \%$ do numero inicial. GUNAY et al $^{44}$ iniciaram seu estudo com 86 gestantes; na avaliação de seis meses contaram com 60 delas e após 3 anos tiveram uma perda de $38 \%$. Portanto, concluímos que, tanto o número inicial de pacientes, como a perda constatada em nosso estudo são aceitáveis e coerentes com os estudos clínicos de mesma natureza. 
O papel do sistema imunológico, assim como a influência de inúmeras variáveis externas não puderam ser controlados neste estudo. AALTONEN et al $^{1,2,3,4}$ verificaram uma possível compensação imunlógica conferida através da passagem de anticorpos séricos e secretores da mãe para o filho. GOMBOS; SERPICO; GAETA $^{41}$ descreveram este mecanismo de forma detalhada. E AALTONEN; TENOVUO; LEHTONEN² desaconselharam o tratamento odontológico durante a gestação.

Porém, os achados significantes em nossa pesquisa mostraram-se, na maioria das vezes, coerentes com a literatura correlata e devem ser entendidos como pontos relevantes a serem considerados na identificação precoce de grupos de risco à cárie da primeira infância e no estabelecimento de ações preventivas itensificadas.

Este estudo pode servir como referencial a programas de saúde pública, por ter como ponto favorável a utilização de dados clínicos de fácil acesso e utilização, o que permitiria o benefício da população mais carente e que concentra grande parte dos grupos de polarização da doença, e encontra-se comumente dessasistida de medidas profiláticas específicas. 
7 - Con clusões 


\section{7 - CONCLUSÕES}

De acordo com a metodologia empregada e a partir dos resultados obtidos, pôde-se concluir que:

1 - A manutenção de um comportamento de risco, refletido pelo acúmulo de placa bacteriana mostrourse significativamente associado com a atividade de cárie, tanto das mães como dos bebês.

2 - O tipo de abordagem desenvolvida sobre as mães do grupo Experimental contribuiu para um menor experiência de cárie nos seus filhos.

3 - Houve correlação significativa entre a atividade de cárie da mãe e a incidência da doença em seu filho. 
An exos 


\section{ANEXO 1 - FICHA DA PACIENTE}

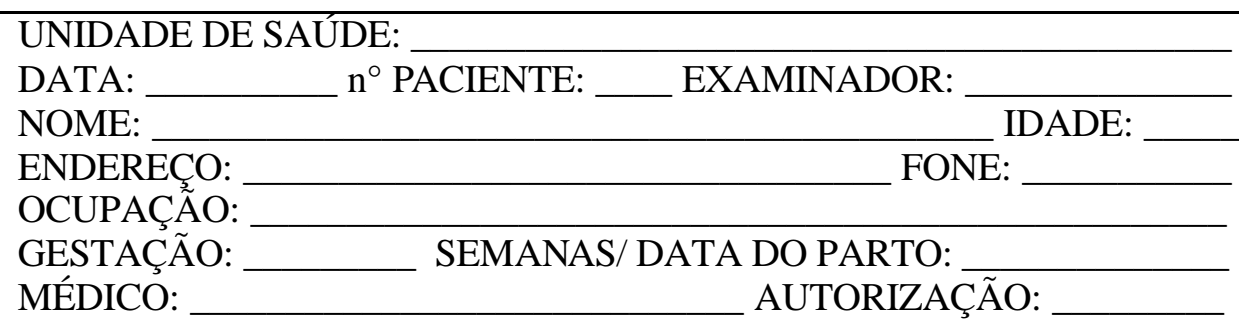

\section{ANAMNESE}

( ) SIM ( ) NÃO Está sob tratamento médico?

Qual?

( ) SIM ( ) NÃO Está tomando algum medicamento?

Qual?

( ) SIM ( ) NÃO Apresenta problemas com a gestação?

Qual?

( ) SIM ( ) NÃO Apresenta alterações de pressão arterial?

( ) SIM ( ) NÃO Apresenta problemas cardíacos?

( ) SIM ( ) NÃO Apresenta problemas pulmonares?

Qual?

( ) SIM ( ) NÃO É diabética? Já fez algum exame?

( ) SIM ( ) NÃO É alérgica a algum medicamento?

Qual?

( ) SIM ( ) NÃO Já tomou anestesia no consultório odontológico?

( ) SIM ( ) NÃO Apresentou algum problema com a anestesia?

Qual?

( ) SIM ( ) NÃO Tem ou teve desmaios ou tonturas?

( ) SIM ( ) NÃO Teve hemorragia ou outro problema após extração dentária?

O objetivo deste trabalho é verificar se a reversão da atividade de cárie em mães de alto risco a esta doença pode prevenir a incidência de lesões em seus filhos. Será realizada a adequação bucal das gestantes (restaurações com cimento de óxido de zinco e eugenol ou cimento de ionômero de vidro; eliminação dos focos infecciosos através de extrações e curativos endodônticos; eliminação de agentes agressores dos tecidos periodontais através de remoção de cálculo e excessos de restaurações); profilaxias, aplicações tópicas de flúor; e descontaminação bucal com solução de iodo.

A avaliação clínica deste programa preventivo requer 2,5 anos de exames periódicos, sendo que os bebês também serão avaliados com as idades de 6,12 e 24 meses.

A pesquisa não oferece riscos à saúde geral da paciente nem a da criança. Não haverá custos. Será feita a documentação dos casos clínicos através de fotografias cavidade bucal da mãe e da criança, sendo a exposição restrita para fins didáticos e científicos. Somente as voluntárias que concordarem em cooperar totalmente com o estudo serão incluídas no mesmo.

A voluntária tem a liberdade de retirar seu consentimento a qualquer momento e deixar de participar do estudo.

Assinatura: 
Paciente:

Última visita ao dentista:

Orientação prévia sobre Higiene Oral: ( ) SIM ( ) NÃO

Foram seguidas:

( ) SIM ( ) NÃO

Quem orientou:

O que foi orientado:

HÁBITOS DE HIGIENE ORAL:

\begin{tabular}{|l|l|l|l|l|l|l|}
\hline $\mathrm{n}^{\circ}$ vezes/dia & Inicial & 1 & 2 & 3 & 4 & 5 \\
\hline Escovação & & & & & & \\
\hline Fio Dental & & & & & & \\
\hline Bochechos & & & & & & \\
\hline
\end{tabular}

Solução:

ÍNDICE PHP

\begin{tabular}{|l|l|l|l|l|l|l|l|}
\hline Data & $16 \mathrm{v}$ & $11 \mathrm{v}$ & $26 \mathrm{v}$ & 461 & $31 \mathrm{v}$ & 361 & PHP \\
\hline & & & & & & & \\
\hline & & & & & & & \\
\hline & & & & & & & \\
\hline & & & & & & & \\
\hline & & & & & & & \\
\hline & & & & & & & \\
\hline
\end{tabular}

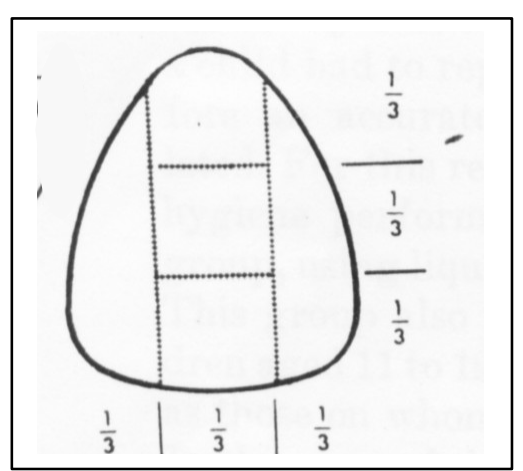

ESTADO PERIODONTAL (ICNTP)

\begin{tabular}{|l|l|l|l|l|l|l|}
\hline Data & $17 / 16$ & 11 & $26 / 27$ & $36 / 37$ & 31 & $46 / 47$ \\
\hline & & & & & & \\
\hline & & & & & & \\
\hline & & & & & & \\
\hline & & & & & & \\
\hline & & & & & & \\
\hline & & & & & & \\
\hline
\end{tabular}

0 - Hígido

1 - Sangramento

2 - Cálculo

3 - Bolsa de 4 a $5 \mathrm{~mm}$

4 - Bolsa $>6 \mathrm{~mm}$

$\mathrm{X}$ - Sextante escluído

FLUXO SALIVAR/ CAPACIDADE TAMPÃO

\begin{tabular}{|l|l|l|l|}
\hline Data & Avaliação & $\begin{array}{l}\text { Fluxo } \\
\text { Salivar }\end{array}$ & C. T. \\
\hline & & & \\
\hline & & & \\
\hline & & & \\
\hline & & & \\
\hline & & & \\
\hline & & & \\
\hline & & & \\
\hline
\end{tabular}



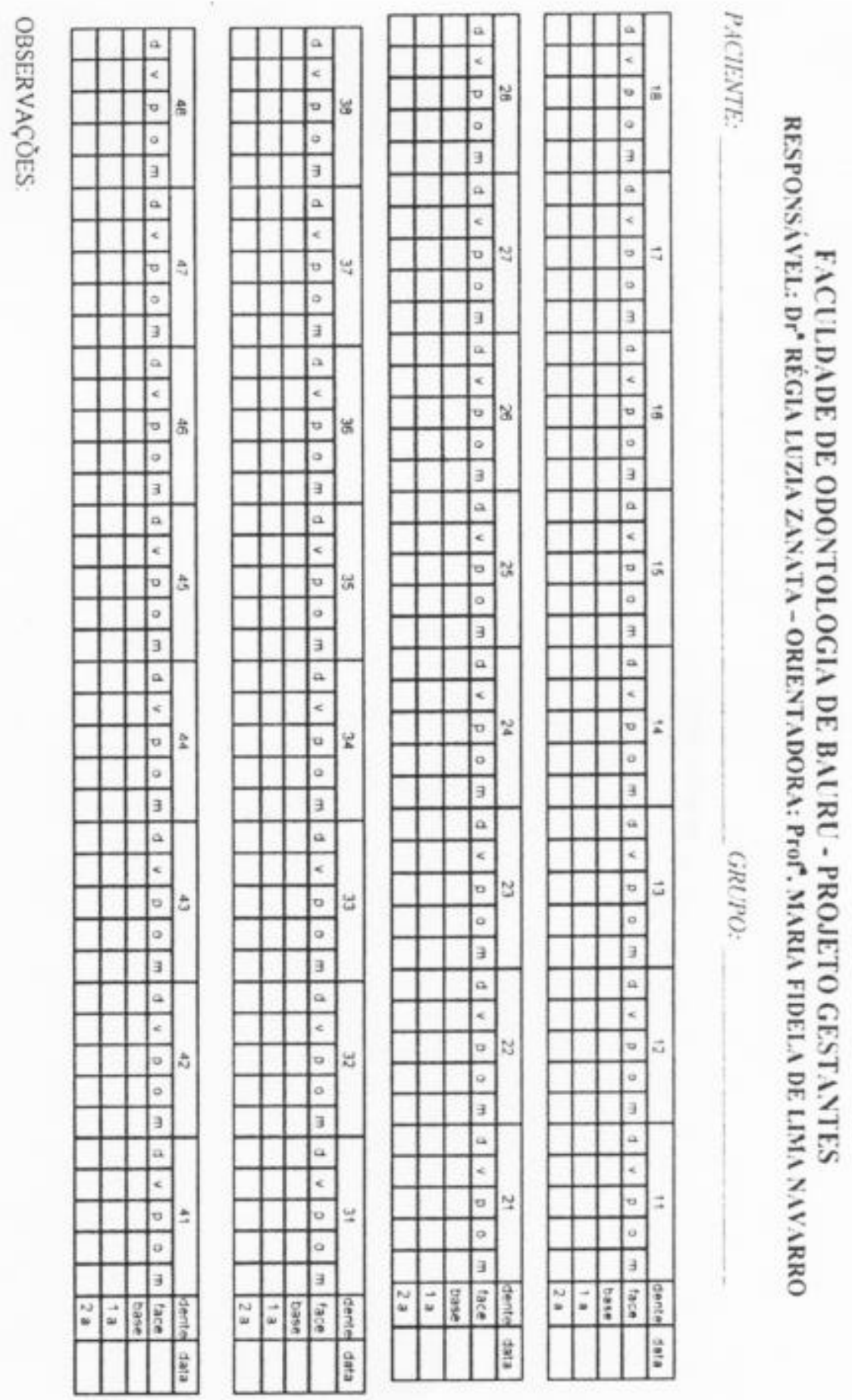


\section{TRATAMENTOS EXECUTADOS}

\begin{tabular}{|l|l|l|}
\hline DATA & TRATAMENTO & OPERADOR \\
\hline & & \\
\hline & & \\
\hline & & \\
\hline & & \\
\hline & & \\
\hline & & \\
\hline & & \\
\hline & & \\
\hline & & \\
\hline & & \\
\hline & & \\
\hline & & \\
\hline & & \\
\hline & & \\
\hline & & \\
\hline & & \\
\hline & & \\
\hline & & \\
\hline & & \\
\hline & & \\
\hline
\end{tabular}

Observações: 


\section{ANEXO 2 - AUTORIZAÇÃO DOS PAIS OU RESPONSÁVEIS}

\section{UNIVERSIDADE DE SÃO PAULO FACULDADE DE ODONTOLOGIA DE BAURU}

Autorizo a menor a participar do Programa de Atenção Odontológica à Gestante.

O objetivo deste trabalho é verificar se a reversão da atividade de cárie em mães de alto risco a esta doença pode prevenir a incidência de lesões em seus filhos. Será realizada a adequação bucal das gestantes (restaurações com cimento de óxido de zinco e eugenol ou cimento de ionômero de vidro; eliminação dos focos infecciosos através de extrações e curativos endodônticos; eliminação de agentes agressores dos tecidos periodontais através de remoção de cálculo e excessos de restaurações); profilaxias, aplicações tópicas de flúor; e descontaminação bucal com solução de iodo.

A avaliação clínica deste programa preventivo requer 2,5 anos de exames periódicos, sendo que os bebês também serão avaliados com as idades de 6,12 e 24 meses.

A pesquisa não oferece riscos à saúde geral da paciente nem a da criança. Não haverá custos. Será feita a documentação dos casos clínicos através de fotografias cavidade bucal da mãe e da criança, sendo a exposição restrita para fins didáticos e científicos. Somente as voluntárias que concordarem em cooperar totalmente com o estudo serão incluídas no mesmo.

A voluntária tem a liberdade de retirar seu consentimento a qualquer momento e deixar de participar do estudo.

Bauru, de de 199

Assinatura do responsável: 
ANEXO 3 - CRITÉRO DE CLASSIFICAÇÃO SÓCIO-ECONÔMICA (ABA/ABIPEME) $)^{5}$

\begin{tabular}{|l|l|l|c|c|c|c|c|}
\hline İTEM & \multicolumn{7}{c|}{ NÚMERO DE BENS NA RESIDÊNCIA } \\
\hline & 0 & 1 & 2 & 3 & 4 & 5 & $6+$ \\
\hline Televisão & 0 & 02 & 04 & 06 & 08 & 10 & 12 \\
Rádio & 0 & 01 & 02 & 03 & 04 & 05 & 06 \\
Banheiro & 0 & 02 & 04 & 06 & 08 & 10 & 12 \\
Carro & 0 & 04 & 08 & 12 & 16 & 16 & 16 \\
Empregada & 0 & 06 & 12 & 18 & 24 & 24 & 24 \\
Aspirador & 0 & 05 & 05 & 05 & 05 & 05 & 05 \\
Máquina & 0 & 02 & 02 & 02 & 02 & 02 & 02 \\
de lavar & & & & & & & \\
& & & & & & & \\
\hline
\end{tabular}

Critério de pontos para bens de consumo duráveis de acordo com o critério ABA/ABIPEME

\begin{tabular}{|l|c|}
\hline NÍVEL EDUCACIONAL & NÚMERO DE PONTOS \\
\hline Analfabeto & 0 \\
Primeiro ciclo do $1^{\circ}$ grau completo & 1 \\
Primeiro grau completo & 3 \\
Segundo grau completo & 5 \\
Universitário completo & 10 \\
\hline
\end{tabular}

Critério de pontos para nível educacional de acordo com o critério da ABA/ABIPEME

Classificação:

$\begin{array}{lllll}0 \text { a } 4 \text { pontos } & - & \text { Classe E } & - & \text { Pobreza Absoluta } \\ 5 \text { a } 9 \text { pontos } & - & \text { Classe D } & - & \text { Baixa } \\ 10 \text { a } 20 \text { pontos } & - & \text { Classe C } & - & \text { Média } \\ 21 \text { a } 34 \text { pontos } & - & \text { Classe B } & - & \text { Média Alta } \\ 35 \text { ou mais } & - & \text { Classe A } & - & \text { Alta }\end{array}$




\section{ANEXO 4 - QUESTIONÁRIO DE DIETA}

\section{QUESTIONÁRIO DE DIETA}

$1^{\circ}$ DIA

Café da manhã hora:

Lanche (cafezinho, salgadinho, doce, fruta, bala etc) hora:

Almoço hora:

Lanche (cafezinho, salgadinho, doce, fruta, bala etc) hora:

Jantar hora:

Lanche (cafezinho, salgadinho, doce, fruta, bala etc) hora:

$2^{\circ}$ DIA

Café da manhã hora:

Lanche (cafezinho, salgadinho, doce, fruta, bala etc) hora:

Almoço hora:

Lanche (cafezinho, salgadinho, doce, fruta, bala etc) hora:

Jantar hora:

Lanche (cafezinho, salgadinho, doce, fruta, bala etc) hora: 


\section{QUESTIONÁRIO DE DIETA}

\section{SÁBADO}

Café da manhã hora:

Lanche (cafezinho, salgadinho, doce, fruta, bala etc) hora:

Almoço hora:

Lanche (cafezinho, salgadinho, doce, fruta, bala etc) hora:

Jantar hora:

Lanche (cafezinho, salgadinho, doce, fruta, bala etc) hora:

DOMINGO

Café da manhã hora:

Lanche (cafezinho, salgadinho, doce, fruta, bala etc) hora:

Almoço hora:

Lanche (cafezinho, salgadinho, doce, fruta, bala etc) hora:

Jantar hora:

Lanche (cafezinho, salgadinho, doce, fruta, bala etc) hora: 


\section{ANEXO 5 - FICHA DO BEBÊ}

\section{FICHA DO BEBÊ}

NOME DO BEBÊ:

DATA DE NASCIMENTO:

NOME DA MÃE:

IDADE DA MÃE: SEXO:

ENDEREÇO:

ESCOLARIDADE DA MÃE:

QUESTIONÁRIO

PROBLEMAS DURANTE GESTAÇÃO / PARTO:

SAÚDE DO BEBÊ (DOENÇAS / USO FREQUENTE DE MEDICAMENTOS QUAIS?)

6 MESES:

12 MESES:

24 MESES:

HORAS QUE FICA AUSENTE DO BEBÊ:

BEIJA O BEBÊ NA BOCA?

USA OS MESMOS TALHERES E COPOS?

LIMPA A CHUPETA COM A BOCA?

FREQUENCIA DE ESCOVAÇÃO ( 2 OU MAIS VEZS POR DIA/ 1 VEZ AO DIA/ 2 VEZES POR SEMANA OU MENOS/ NUNCA)

6 MESES:

12 MESES:

24 MESES:

APÓS MAMENTAÇÃO NOTURNA ESCOVA (SEMPRE/ RARAMENTE/ NUNCA)

$6 \mathrm{M}$ $12 \mathrm{M}$ $24 \mathrm{M}$

COMO FAZ A LIMPEZA (FRALDA/ GAZE/ ESCOVA/ PASTA - QUANT.)

6 MESES:

12 MESES:

24 MESES: 
A CRIANÇA É RECEPTIVA? (SIM/ NÃO/ ÁS VEZES)

$6 \mathrm{M}$ $12 \mathrm{M}$ $24 \mathrm{M}$

OBSERVAÇÕES

ALIMENTAÇÃO

AMAMENTAÇÃO (PEITO/ MAMADEIRA/ AMBAS)

6 MESES:

12 MESES:

24 MESES:

MAMADEIRA

LEITE (TIPO)

ADOÇANTE

FARINÁCEOS

CHÁ (ADOÇADO)

SUCO (ADOÇADO)

MAMA ANTES DE DORMIR? E DORMINDO, QUANTAS VEZES? ESTA MAMADEIRA TAMBÉM É DOCE?

6 MESES:

12 MESES:

24 MESES:

FREQUENCIA (1 OU MAIS VEZES POR DIA/ 2 VEZES POR SEMANA/ 1 VEZ POR SEMANA OU MENOS/ NUNCA), IDADE DE INTRODUÇÃO DOS ALIMENTOS

BALA/ CHICLETE/ PIRULITO

BOLACHA

CHOCOLATE

REFRIGERANTE

IOGURTE E SIMILARES 
EXAME CLINICO

\begin{tabular}{|l|l|l|l|l|}
\hline DATA & IDADE & DENTES PRESENTES & $\mathbf{N}^{\circ}$ SUPERFÍCIES LMB & $\begin{array}{l}\mathbf{N}^{\circ} \text { SUPERFÍCIES } \\
\text { CAVIDADES }\end{array}$ \\
\hline & & & & \\
\hline & & & & \\
\hline & & & & \\
\hline
\end{tabular}

\section{ODONTOGRAMA}
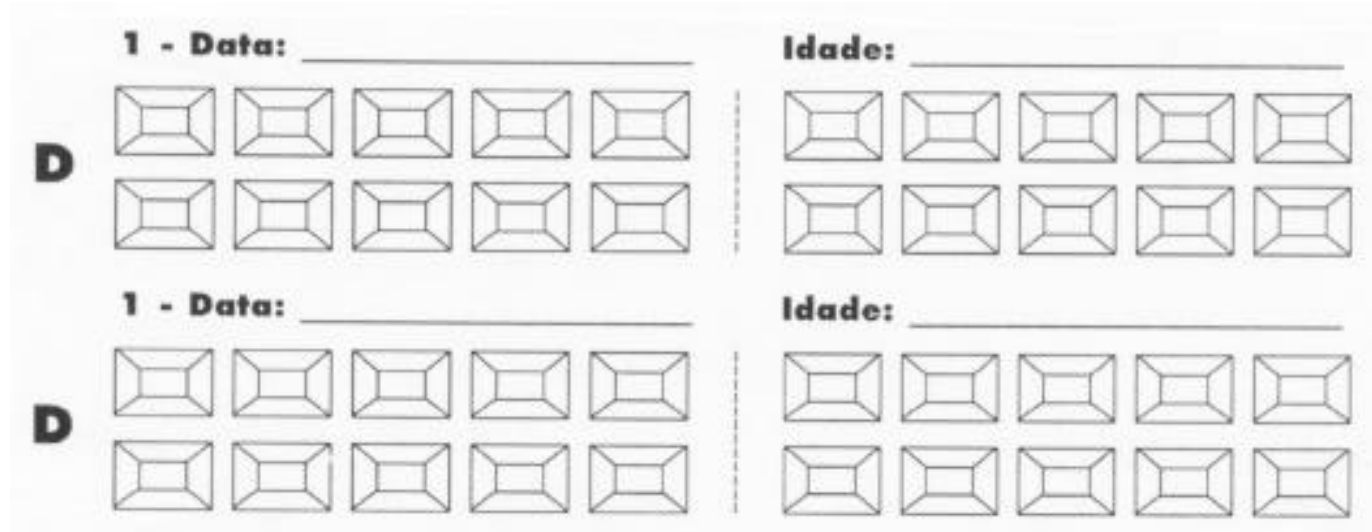

Idade:

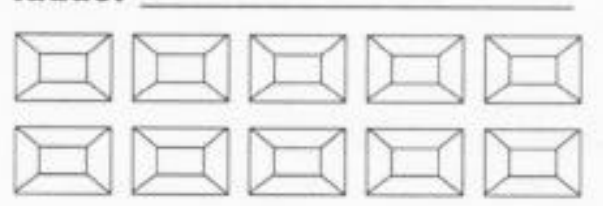

E 
ANEXO 6 - FOLDER

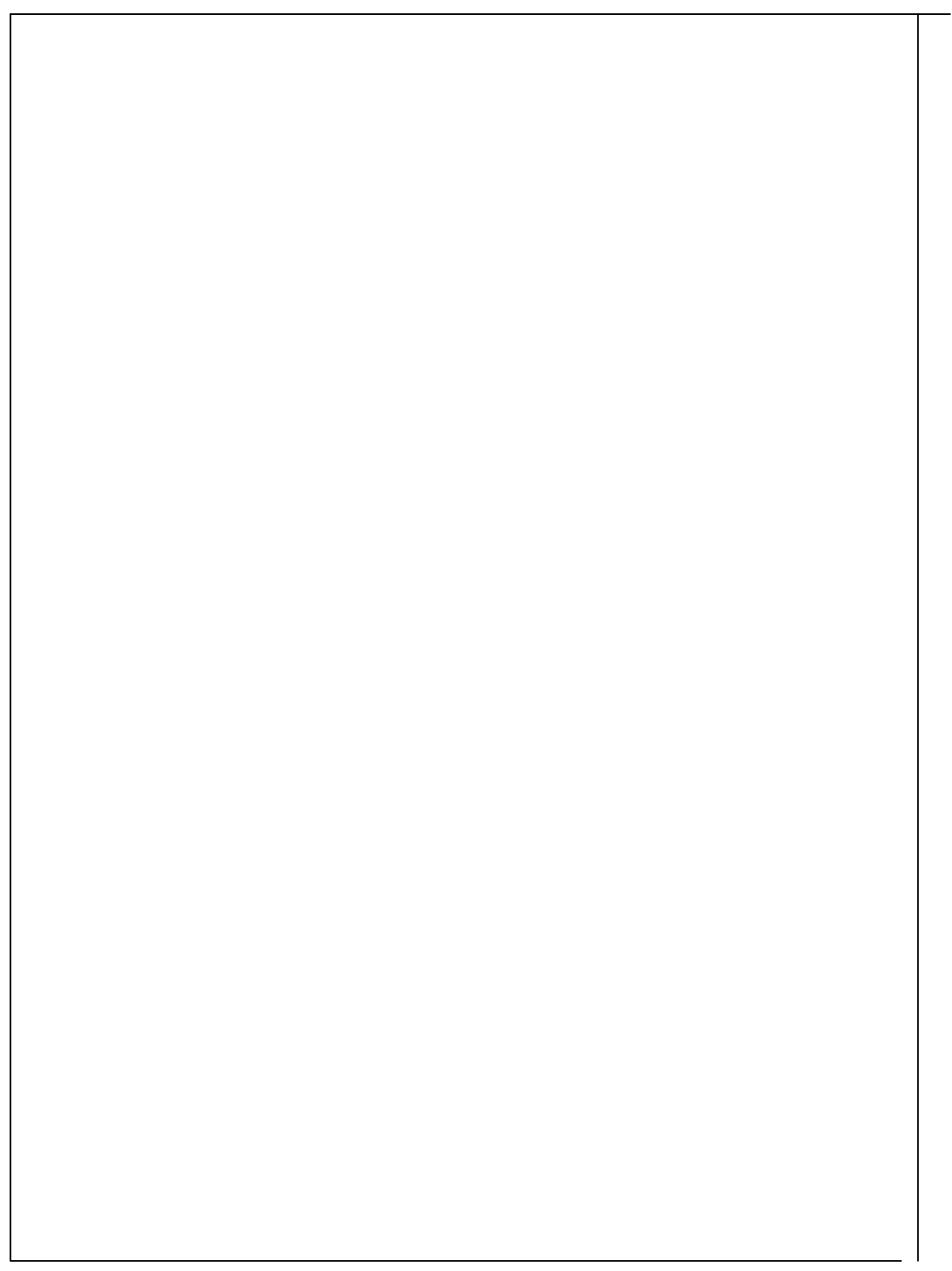




$$
\begin{array}{r}
\text { Referên cias } \\
\text { Bibliográfica s }
\end{array}
$$




\section{REFERÊNCIAS BIBLIOGRÁFICAS *}

1. AALTONEN, A.S. The frequency of mother-infant salivary close contacts and maternal caries activity affect caries occurrence in 4-year-old children. Proc. Fin. dent. soc., v. 87, n. 3, p. 373-81, 1991.

2. AALTONEN, A.S.; TENOVUO, J.; LEHTONEN, O.P. Antibodies to the oral bacterium Streptococcus mutans and the development of caries in children in relation to maternal dental treatment during pregnancy. Arch. oral Biol., v. 33, n. 1, p. 33-9, 1988.

3. AALTONEN, A.S. et al. Serum antibodies against oral Streptococcus Mutans in young children in relation to dental caries and maternal close-contacts. Arch. oral Biol., v. 30, n. 4, p. 331-5, 1985.

4. AALTONEN, A.S. et al. Maternal caries incidence and salivary close-contacts with children affect antibady levels to Streptococcus mutans in children. Oral microbiol. Immunol., v. 5, p. 12-8, 1990.

5. ABA/ABIPEME. Critério de classificação sócio-econômica. Rio de Janeiro, ABA, 1978.

6. ABDAlla, A.E. et al. Cuidados com a gestante. J. Amer. dent. Ass. (Brasil), v. 2, p. 78-80, Ago. 1999.

7. AlaluUSuA, S. Transmission of Mutans streptococci. Proc. Fin. dent. soc., v. 87, n. 4 , p. $443-7,1991$.

8. ALALUUSUA, S.; MALMIVIRTA, R. Early plaque accumulation - a sing for caries risk in young children. Community Dent. oral Epidem., v. 22, p. 273-6, 1994. 
9. ALALUUSUA, S.; RENKONEN, O.V. Streptococcus mutans establishment and dental caries experience in children from 2 to 4 years old. Scand. J. dent. Res., v. 91, p. 453-7, 1983.

10.BAKHMUDOV, B.R.; BAKHMUDOVA, Z.B. Caries prevalence and intensity and the health and hygiene habits of oral care in pregnant women. Stomatologiia, v. 79, n. 3, p. 12-4, 2000. / Abstract/ [Russian].

11.BELLINI, H.T.; ARNEBERG, P.; VON DER FEHR, F.R. Oral hygiene and caries. A review. Acta odont. scand., v. 39, p. 257-65, 1981.

12.BERKOWITZ, R.J. Etiology of nursing caries: a microbiologic perspective. J. Publ. HIth Dent., v. 56, n. 1, p. 51-4, Spring 1996.

13.BERKOWITZ, R.J.; JONES, P. Mouth-to-mouth transmission of the bacterium Streptococcus mutans between mother and child. Arch. oral Biol., v. 30, n. 4, p. 377-9, 1985.

14.BERKOWITZ, R.J.; JORDAN, H.V. Similarity of bacteriocins of Streptococcus mutans from mother and infant. Arch. oral Biol., v. 20, p. 725-30, 1975.

15.BERKOWITZ, R.J.; JORDAN, H.V.; WHITE, G. The early establishment of Streptococcus mutans in the mouths of infants. Arch. oral Biol., v. 20, p. $171-4,1975$.

16.BERKOWITZ, R.J.; TURNER, J.; GREEN, P. Primary oral infection of infants with Streptococcus mutans. Arch. oral Biol., v. 25, p. 221-4, 1980.

17.BERKOWITZ, R.J.; TURNER, J.; GREEN, P. Maternal salivary levels of Streptococcus mutans and primary oral infection of infants. Arch. oral Biol., v. 26, p. $147-9,1981$. 
18. BLINKHORN, A.S. Dental preventive advice for pregnant and nursing mothers sociological implications. Int. dent. J., v. 31, n. 1, p. 14-22, 1981.

19.BOTTINO, M.A.; MOREIRA, E.J.G.; ROSSETINI, S.M.O. Estabelecimento de hábitos de higiene bucal em pacientes adultos. Rev. Ass. paul. cirurg. Dent., v. 36, n. 3, p. 280-6, maio/jun. 1982.

20.BRAMBILLA, E. et al. Caries Prevention during pregnancy: results of a 30-month study. J. Amer. dent. Ass., v. 129, p. 871-7, July 1998.

21. BRASIL. MINISTÉRIO DA SAÚDE. SECRETARIA DE ASSIS TÊNCIA À SAÚDE. Programa Nacional de DST/AIDS. Hepatites, AIDS e herpes na prática odontológica. Brasília, Ministério da Saúde, 1996.

22. BRASIL. MINISTÉRIO DA SAÚDE. SECRETARIA NACIONAL DE PROGRAMAS ESPECIAIS DE SAÚDE. DIVISÃO NACIONAL DE SAÚDE MATERNOINFANTIL E INSTITUTO NACIONAL DE ASSISTÊNCIA MÉDICA DA PREVIDÊNCIA SOCIAL. Assistência pré-natal. 2 ed. Brasília, 1988.

23. CAUFIELD, P.W.; GIBBONS, R.J. Supression of Streptococcus mutans in the mouths of humans by a dental prophylaxis and tropically-applied lodine. $\mathbf{J}$. dent. Res., v. 58, n. 4, p. 1317-26, Apr. 1979.

24.CAUFIELD, P.W.; CUTTER, G.R.; DASANAYAKE, A.P. Inicial acquisition of Mutans streptococci by infants: evidence for a discrete window of infectivity. J. dent. Res., v. 72, n. 1, p. 37-45, Jan. 1993.

25. CHAPMAN, P.J.; et al. A dental survey of an antenatal population. Aust. dent. J., v. 19, n. 4, p. 261-8, Aug. 1974.

26. COMMUNITY DENTISTRY AND ORAL EPIDEMIOLOGY. Copenhagen, v. 26, 1998. Supplement 1. 
27. COMMUNITY DENTISTRY AND ORAL EPIDEMIOLOGY. Copenhagen, v. 27, n. 6, Dec. 1998.

28. COSTA, I. do C.C. et al. A gestante como agente multiplicador de saúde. Ver. Pós-grad. (São Paulo), v. 5, n. 2, p. 87-92, abr./jun. 1998.

29.COUTO, J.L.; COUTO, R. da S.; DUARTE, C.A. Motivação do paciente: avaliação dos recursos didáticos de motivação utilizados para prevenção da cárie e doença periodontal. Rev. gaúcha Odont., v. 40, n. 2, p. 143-50, mar./abr. 1992.

30.COZZUPOLI, C.A. Odontologia na gravidez. São Paulo, Panamed Editorial, 1981.

31.DASANAYAKE, A.P. Poor periodontal health of the pregnant woman as a risk factor for low birth weight. Annals Periodontology., v.3, n.1, p.206-12, 1998.

32.DASANAYAKE, A.P. et al. Transmission of Mutans streptococci to infants following short term application of an iodine-Naf solution to mothers' dentition. Community Dent. oral Epidem., v. 21, p. 136-42, 1993.

33.DEYU, H.; DAWEI, L. Trends of caries prevalence and experience in children in Chengdu City, west China, 1982-90. Community Dent. oral Epidem., v.20, p.308-9.

34.DÍAZ-ROMERO, R.M. et al. Mitos, prejuicios y realidades del tratamiento odontológico durante el embarazo. Opinión médica. Ginec. Obst. Mex., v. 66, p. 507-11, dic. 1998.

35.DUTRA, G.V.; AZEVEDO, I.D.; FIGUEIREDO, M.C. Cárie dentária: uma doença transmissível. Rev. bras. Odont., v. 54, n. 5, p. 293-6, set./out. 1997. 
36.EDWARDS, T.S.F.; ROWNTREE, F.St.D. Dental attitudes of primigravid women. J. Periodont. Res., v. 4, n. 4, p. 325-32, 1969.

37. ELIAS, R. Odontologia na gravidez. In: Odontologia de alto risco pacientes especiais. Rio de Janeiro, Resvinter, 1995. p. 117-32.

38.FASSMAN, D.K. Prenatal Fluoridation. N. Y. St. dent. J., p. 47-51, June/July 1993.

39. FUJIWARA, T. et al. Caries prevalence and salivary Mutans streptococci in 0-2years-old children of Japan. Community dent oral Epidem., v. 19, p. 151$4,1991$.

40.GOELPEL, E. et al. The need for cooperation between the gynecologist and dentist in pregnancy. A study of dental health education in pregnancy. Geburtshilfe Frauenheilkd, v. 51, n. 3, p. 231-5, Mar. 1991. /Abstract/ [Germany].

41.GOMBOS, F.; SERPICO, R.; GAETA, G.M. Le basi immunologiche della vacina profilassi nela malattia cariosa. Rapporti madre-feto. Fatori di difesa specifici dell'ospite. Arch. Stomat., v. 30, p. 771-90, 1989.

42. GRINDEFJORD, M. et al. Caries prevalence in 2.5-year-old children. Caries Res., v. 27, p. 505-10, 1993.

43. GRINDEFJORD, M. et al. Prediction of dental caries development in 1-year-old children. Caries Res., v. 29, p. 343-8, 1995.

44. GUNAY, H. et al. Effect on caries experience of a long-term preventive program for mothers and children starting during pregnancy. Clin. oral Investig, v. 2, n. 3, p. 137-2, Sep. 1998. 
45. HORMONES lead to special considerations. J. Calif. dent. Ass., v. 25, n. 8, p. 535, Aug. 1997.

46. Van HOUTE, J.V.; YANOVER, L.; BRECHER, S. Relationship of levels of the bacterium Streptococcus Mutans in saliva of children and their parents. Arch. oral Biol., v. 26, p. 381-6, 1981.

47.ISLMAIL, A.I. Clinical diagnosis of precavitated carious lesions. Community dent. oral Eidem., v. 25, p. 13-23, 1997.

48.JAGO, J.D. et al. Dental Status of pregnant women attending a Brisbane maternity hospital. Community dent. oral Epidem., v. 12, n. 6, p. 398-404, 1984.

49.JENDRESEN, M.D.; PHILLIPS, R.W. A comparative study of four zinc oxide and eugenol formulations as restorative materials. Part II. J. prosth. Dent., v. 21, n. 3, p. 300-9, 1969.

50.JENDRESEN, M.D. et al. A comparative study of four zinc oxide and eugenol formulations as restorative materials. Part I. J. prosth. Dent., v. 21, n. 2, p. 176-83, 1969.

51.JOURNAL OF PUBLIC HEALTH DENTISTRY. Iowa, v. 56, n. 3, 1996. Special issue.

52.KALSBEEK, H.; VERRIPS, G.H. Influence of mothers' preventive attitudes on the caries experience of 6- and 15-year-old children. Caries Res., v. 25, p. 213, 1991. /Abstract 3/

53.KEYES, P.H. The infectious and transmissible nature of experimental dental caries. Findings and implications. Arch. oral Biol., v.1, p.304-20, 1960. 
54.KIDD, E.A.M. The use of diet analysis and advice in the management of dental caries in adult patients. Oper. Dent., v. 20, p. 86-93, 1995.

55.KIDD, E.A.M.; RICKETTS, D.N.J.; PITTS, N.B. Occlusal caries diagnosis: a changing challenge for clinicians and epidemiologists. J. Dent., v. 21, n. 6 , p. 323-31, 1993.

56. KLEIN, H. The family and dental disease. IV. Dental disease (DMF) experience in parents and offspring. J. Amer. dent. Ass., v. 33, p. 735-43, June 1946.

57.KLIGERMAN, B.A.; BISSADA, N.F. Clinical study of lodine as a chemotherapeutic agent for the control of dental plaque and gingivitis in man. J. Periodont., v. 46, n. 8, p. 478-87, 1975.

58. KÖHLER, B.; ANDREEN, I. Influence of caries-preventive measures in mothers on cariogenic bacteria and caries experience in their children. Arch. oral Biol., v. 39, n. 10, p. 907-11, 1999.

59.KÖHLER, B.; ANDREEN, I.; JONSSON, B. The effect of caries-preventive measures in mothers on dental caries and the oral presence of the bacteria Streptococcus Mutans and Lactobacilli in their children. Arch. oral Biol., v. 29, n. 11, p. $879-83,1984$.

60.KÖHLER, B.; BRATTHALL, D. Intrafamilial levels of Streptococcus Mutans and some aspects of the bacterial transmission. Scand. J. dent. Res., v. 86, p. 35-42, 1978.

61.KÖHLER, B.; BRATTHALL, D.; KRASSI, B. Preventive measures in mothers influence the establishment of the bacterium Streptococcus mutans in their infants. Arch. oral Biol., v. 28, n. 3, p. 225-31, 1983. 
62.KÖHLER, B. et al. Effect of caries preventive measures on Streptococcus mutans and Lactobacilli in selected mothers. J. dent. Res., v. 90, p. 102-8, 1982.

63. KÖNÖNEN, E.; JOUSIMIES-SOMER, H.; ASIKAINEN, S. Relationship between oral gram-negative anaerobic bacteria in saliva of the mother and the colonization of the her edentulous infant. Oral Microbiol. Immunol., v. 7, p. 273-6, 1992.

64.KRAMER, P.F.; FELDENS, C.A.; ROMANO, A.R. Promoção de saúde bucal em odontopediatria: diagnóstico, prevenção e tratamento da cárie oclusal. São Paulo. Artes Médicas, 1997. 144p.

65. LAINE, M.; PIENIHAKKINEU, K. Salivary buffer effect in relation to late pregnancy and postpartum. Acta odont. Scand., v. 58, n. 1, p. 8-10, 2000.

66. LAINE, M.; et al. Pregnancy-related changes in human whole saliva. Arch. oral Biol., v. 33, n.12, p. 913-7, 1988.

67. LEBER, P. M.; CORRÊA, M. S. N. P. Dieta. In: Odontopediatria na primeira infância. São Paulo, Ed. Santos, 1998. Cap. 23, p. 279-89.

68. LI, Y.; CAUFIELD, P.W. The fidelity of initial acquisition of Mutans streptococci by infants from their mothers. J. dent. Res., v. 74, n. 2, p. 681-5, Feb. 1995. 69. LIEFDE, B. The dental care of pregnant women. N. Z. dent. J., v. 80, p. 41-3, Apr. 1984.

70.LIVINGSTON, H.M.; DELLINGER, T.M.; HOLDER, R. Considerations in the management of the pregnant patient. Spec. care Dent., v. 18, n. 5, p. 1838, 1998. 
71. LLOYD, P.F. Pregnancy and dentistry. J. dent. Ass. S. Afr., v. 34, p. 763-5, Nov. 1979.

72.MALTZ, M.; RUPPENTHAL, L.C.F.; JARDIM, J.J. Bases biológicas para a remoção de dentina cariada. Rev. ABOPREV (Porto Alegre), v. 2, n. 1, maio 1999.

73. MARTINS, A.L.C.F. et al. A cárie dentária. In: Odontopediatria na primeira infância. São Paulo, Ed. Santos, 1998. Cap. 17, p. 195-208.

74.MATTOS-GRANER, R. de O. et al. Caries prevalence in 6-36-month-old Brazilian children. Community dent. HIth, v. 13, p. 96-8, 1996.

75. MATTOS-GRANER, R. de O. et al. Association between caries prevalence and clinical, microbiological and dietary variables in 1.0 to 2.5 -year-old brazilian children. Caries Res., v. 32, n. 5, p. 319-23, 1998.

76. MAXI-ODONTO: DENTÍSTICA. Bauru, v.1, n. 4, jul./ago. 1995.

77. McCABE, M.; KINIRONS, M. Dental caries and dental registration status in nursery school children in Newry, Northern Ireland. Community dent. oral Epidem., v. 23, p. 69-71, 1995.

78. MEES, M.L.; PORTELA, I.C.; CARLINI, J.L. Uso dos anestésicos locais em odontologia. Rev. bras. Odont., v. 54, n. 5, p. 273-6, set./out. 1997.

79.MENINO, R.T.M. Necessidades de saúde bucal em gestantes dos núcleos de saúde de Bauru. Conhecimentos com relação à própria saúde bucl e a da criança. Bauru, 1995. 82 p. Tese (Doutorado) - Faculdade de odontologia, Universidade de São Paulo.

80.MILLER, M.C. The pregnant dental patient. J. Calif. dent. Ass., v. 23, n. 8, p. 63-70, Aug. 1995. 
81. MILNES, A.R. Description and epidemiology of nursing caries. J. Publ. Hlth. Dent., v. 56, n. 1, p. 38-50, Spring 1996.

82. MJÖR, I.A. Glass-ionomer cement restorations and secondary caries. A premilinary report. Quintessence Int., v.27, n. 3, p. 171-4, 1996.

83. MJÖR, I.A.; GORDAN, V.V. A review of atraumatic restorative treatment (ART). Int. dent. J., v. 49, n. 3, p. 127-31, 1999.

84.NASCIMENTO, Z.C.P.; LOPES, W.C. Gravidez na adolescência: enfoque odonto-preventivo. Rev. Odont. Brasil Central, v. 6, n. 20, p. 27-31, 1996.

85. NEWBRUN, E.; HEIBLUM, R.; MAYEDA, A. Effect of flossing, with and without lodine, on human interproximal plaque flora. Caries Res., v. 14, p. 75-83, 1980.

86. O'CONNELL, A.C.; BOWEN, W.H. Influence of rampant caries in dams on caries activity in their offspring. Pediat. Dent., v. 13, n. 6, p. 361-366, p. Nov/Dec 1991.

87. OLIVEIRA, L.M.C. de et al. Tratamento restaurador atraumático e adequação do meio bucal. Rev. bras. Odont., v. 55, n. 2, p. 94-9, 1998.

88. ORGANIZAÇÃO MUNDIAL DE SAÚDE. Levantamentos básicos em saúde bucal. 4 ed. , São Paulo, Ed. Santos, 1999.

89.PAPP, E. et al. Longitudinal study of the dental status of pregnant women under prenatal care. Fogorv Sz, v. 83, n. 7, p. 199-204, Jul 1990 [Hungrian].

90.PEREZ, M.S. et al. Avaliação do CPOS modificado, do índice de placa visível e de sangramento gengival em 30 pares mãe-filho. Cecade News, v. 4, n. 1 / 2, p. 35-45, jan./ago. 1996. 
91.PODSHADLEY, A.G.; HALEY, J.V. A method for evaluating oral hygiene performance. Publ. Hlth. Rep., v. 83, n. 3, p. 259-64, Mar. 1968.

92.ROCHA, M.C.B.S. Avaliação dos conhecimenos e das práticas de saúde bucal - gestantes do Distrito Sanitário Docente Assistencial Barra/ Rio Vermelho - Município de Salvador - BA. 300 p. São Paulo. 1993. Tese (Doutorado) - Faculdade de Odonologia, Universidade de São Paulo.

93.ROSSEL, F.L.; MONTANDON-POMPEU, A.A.B.; VALSECKI JR, A. Registro periodontal simplificado em gestantes. Rev. saúde públ. (São Paulo), v. 33, n. 2, p. 157-62, 1999.

94.SALONEN, L. et al. Mutans Streptococci, oral hygiene, and caries in a adult Swedish population. J. dent. Res., v. 69, n. 8, p. 1469-75, Aug. 1990.

95. SALVOLINI, E. et al. Biochemical modifications of human whole saliva induced by pregnancy. Brit. Obstet. Gynaecol., v. 105, n. 6, p. 656-60, June 1998. 96.SARNAT, H.; KAGAN, A.; RAVIV, A. The relation between mothers attitude toward dentistry and the oral status of their children. Pediat. Dent., v. 6, n. 3, p. 128-31, 1984.

97.SCAVUZZI, A.I.F. Estudo da prevalência da cárie dentária e doença periodontal em gestantes: Distrito Sanitário Docente Assistencial Barra/Rio Vermelho, Salvador - Bahia. Salvador, 1995. $111 \mathrm{p}$. Dissertação (Mestrado) - Faculdade de Odontologia, Universidade Federal da Bahia.

98.SCHEIE, A.A. Mechanisms of dental plaque formation. Adv. dent. Res., v. 8, n. 2, p. 246-53, July 1994. 
99.SHEIN, B.; TSAMTSOURIS, A.; ROVERO, J. Self reported compliance and the effectiveness of prenatal dental education. J. Clin. Ped. Dent, v. 15, n. 2, p. 102-108, 1991.

100. SHROUT, M.K. et al. Treating the pregnant dental patient: four basic rules addressed. J. Amer. dent. Ass., v. 123, p. 75-80, May 1992.

101. SILVEIRA, A. M. M. Avaliação das condições relativas à cárie em gestantes. In: ENCONTRO CIENTÍFICO DE PÓS-GRADUAÇÃO, 1, Bauru, 1996. Anais. Bauru, FOB-USP,1996. p.15.

102. SLAVKIN, H.C. First encounters: transmission of infectious oral diseases from mother to child. J. Amer. dent. Ass., v. 128, p. 773-8, June 1997.

103. SMALES, R.J.; FANG, D.T.S. "In vitro" effectiveness of hand excavation of caries with the ART Technique. Caries Res., v. 33, n. 6, p. 437-40, 1999.

104. SÖDERLING, E. et al. Influence of maternal Xylitol consumption on acquisition of Mutans streptococci by infants. J. dent. Res., v.79, n. 3, p. 882-7, 2000.

105. SPOSTO, M.R. et al. Atendimento odontológico da paciente gestante: complicações e cuidados a serem adotados. Odonto 2000 , v. 1, n. 1, p. 20$3,1997$.

106. SVANBERG, M.; MJÖR, I.A.; RSTAVIT, D. Mutans Streptococci in plaque from margins of amalgam, composite and glass-ionomer restorations. $\mathbf{J}$. dent. Res., v. 65, n. 3, p. 861-4, Mar. 1990.

107. TANZER, J.M. Dental caries is a transmissible infectious disease: the Keyes and Fitzgerald Revolution. J. dent. Res., v. 74, n. 9, p. 1536-42, 1995. 
108. TENOVUO, J.; et al. Effects of chlorhexidine-fluoride gel treatments in mothers on the establishment of Mutans Streptococci in primary teeth and the develoment of dental caries in children. Caries Res., v. 26, p. 275-80, 1992. 109. THYLSTRUP, A.; FEJERSKOV, O. Textbook of clinical cariology. 2 ed. Munksgaard, Copenhagen 1994.

110. TOMITA, N.E. Prevalência de cárie dentária em crianças de faixa etária de 0 a 6 anos em creches dos municípios de Bauru e São Paulo. Importância de fatores sócio-econômicos. Bauru, 1993. 291p. Dissertação (Mestrado) - Faculdade de Odontologia de Bauru, Universidade de São Paulo.

111. TOMITA, N.E.; BASTOS, J.R.M.; BIJELLA, V.T. Placa bacteriana dental processo de formação e potencial patogênico. Bauru, FOB-USP, 1990. /Material didático/

112. TSAMTSOURIS, A.; STACK, A.; PADAMSEE, M. Dental education of expectant parents. J. Pedod., v. 10, n. 4, p. 309-22, 1986.

113. TSUBOUCHI, J. et al. A study of baby bottle tooth decay and risk factors for 18-month old infants in rural Japan. J. Dent. Child., p. 293-8, July/Aug. 1994.

114. TUUTTI, H. et al. Comparison of dental caries experience of parents of cariesfree and caries-active chi ldren. J. paediat. Dent., v. 5, p. 93-8, 1989.

115. VALLADÃO JR, C.A. do A.; SOUZA, J.A. Tratamento odontológico durante a gravidez. Odont. mod., v. 20, n. 2, p. 27-8, 1993. 
116. VIEIRA, A.L.F. Avaliação clínica da efetividade de remoção mecânica de placa dentária por diferentes dispositivos utilizados para a higiene bucal em bebês. Bauru, 2000. 109p. Dissertação (Mestrado) - Faculdade de Odontologia de Bauru, Universidade de São Paulo.

117. VILLENA, R. S.; CURY, J. A. Flúor - aplicação sistêmica. In:

Odontopediatria na primeira infância. São Paulo, Ed. Santos, 1998. Cap. 24, p. $291-314$

118. WALTER, L.R.F.; FERELLE, A.; ISSAO, M. Odontologia para o bebê: odontopediatria do nascimento aos 3 anos. São Paulo, Artes Médicas, 1996.

119. WATSON, A.K. Local anaesthetic in pregnancy. Brit. dent. J., v. 165, n. 8, p. 278-9, Oct .1988.

120. WEERHEIJM, K.L. et al. The effect of glass-ionomer cement on carious dentine: na "in vivo" study. Caries Res., v. 27, p. 417-23, 1993.

121. WENDT, L.K.; HALLONSTEN, A.L.; KOCH, G. Dental caries in one- and twoyears-old children living in Sweden. Swed. dent. J., v. 15, p. 1-6, 1991.

122. WENDT, L.K.; HALLONSTEN, A.L.; KOCH, G. Oral health in preschool children living in Sweden. Swed. dent. J., v. 16, p. 41-9, 1992.

123. WRIGHT, J.T. et al. Effect of conventional dental restorative treatment on bacteria in saliva. Community Dent. oral Epidem., v. 20, p. 138-43, 1992.

124. ZANATA, R.L. et al. Levantamento epidemiológico da condição de saúde bucal (CPOD/ICNTP) de gestantes do município de Bauru. In: ENCONTRO DO GRUPO BRASILEIRO DOS PROFESSORES DE DENTÍSTICA, 12, Vitória, 1997, Anais. p. 39. 
125. ZICKERT, I.; EMILSON, C.G.; KRASSE, B. Effect of caries preventive measures in children highly infected with the bacterium Streptococcus mutans. Arch. oral Biol., v. 27, p. 861-8, 1982. 
Abstra ct 


\section{ABSTRACT}

\section{Effect of caries-preventive measures directed to expectant mothers on caries experience in their children}

The aim of this long-term study was to determine the effectiveness of a cariespreventive program starting during pregnancy on the caries experience of first time mothers and their infants. Eighty-one pregnant women from low social background were selected on the basis of presence of active carious lesions (initial DS 13.98). Initial dental status (DMFS and white spot lesions) and periodontal score (CPITN) were established by clinical examination. Salivary flow rate and buffer capacity were also analyzed. Sixty-four mother-child couples ended the study; thirty-four were in the test group and thirty in the control group. Seventy five per cent of the mothers aged among 14 and 20 years at baseline, and were classified as adolescents. The prophylactic measures, aiming a reduction in caries-risk, were repeated at intervals of 6 months: during pregnancy and 6 and 12 months after delivery. Both groups received educational approach (information about caries etiologic factors, its transmission and prevention, oral hygiene instructions and dietary counseling). Test group also received antimicrobial treatment (professional tooth cleaning and fluoride and iodine topical applications), and restorative care using a glass-ionomer cement. At the children age of 2 years, 33.3 per cent of the infants in the control group were caries-active, compared with 14.7 per cent in the test group. A significant difference 
in caries prevalence was observed between children with and without visible dental plaque $(p=0.032)$. The mean ds (including initial caries) was higher in children of control group than in test group $(6.3 \times 3.2)$, although not statistically significant. Five children in control group exhibited six or more decayed surfaces compared with no children in this situation on test group. Mothers caries increment among baseline and last recall was assessed and was a significant factor in the caries experience of the children $(p=0.0009)$. These data support the evidence of an association between caries prevalence in young children and clinical (dental plaque) and maternal factors. 